Basin Research

June 2017, Volume 29, Issue 3, Pages 305-339

http://dx.doi.org/10.1111/bre.12178

http://archimer.ifremer.fr/doc/00310/42087/

(C) 2015 The Authors Basin Research (C) 2015 John Wiley \& Sons Ltd,

European Association of Geoscientists \& Engineers and International

Association of Sedimentologists

\title{
High resolution evolution of terrigenous sediment yields in the Provence Basin during the last 6 Ma: relation with climate and tectonics
}

\author{
Leroux Estelle ${ }^{1,2,3,{ }^{*} \text {, Rabineau Marina }}{ }^{2}$, Aslanian Daniel ${ }^{3}$, Gorini Christian ${ }^{1}$, Molliex Stephane ${ }^{2,3}$, \\ Bache Francois ${ }^{4}$, Robin Cécile ${ }^{5}$, Droz L.Aurence ${ }^{2}$, Moulin Maryline ${ }^{3}$, Poort Jeffrey ${ }^{1}$, \\ Rubino Jean Loup ${ }^{6}$, Suc Jean Pierre ${ }^{1,7}$
}

${ }^{1}$ Sorbonne Universités, UPMC, Univ. Paris 06, UMR 7193; Institut des Sciences de la Terre de Paris (iSTeP); F-75005 Paris, France

${ }^{2}$ CNRS, UMR6538; Domaines Océaniques, IUEM; 29280 Plouzané, France

3 IFREMER, DRO/GM/LGG; BP 7029280 Plouzané, France

${ }^{4}$ Santos Ltd; GPO Box 2975 Melbourne VIC 3001, Australia

${ }^{5}$ Université Rennes 1; Campus de Beaulieu 35042 Rennes Cedex, France

${ }^{6}$ CSTJF, Centre Scientifique et Technique Jean Feger, TOTAL; Avenue Laribau 64018 Pau ,France

${ }^{7}$ CNRS, UMR 7193; Institut des Sciences de la Terre de Paris (iSTeP); F-75005 Paris, France

*Corresponding author : Estelle Leroux, email address : stll.leroux@gmail.com

\begin{abstract}
:
Basin-wide correlation of Messinian units and Plio-Quaternary chronostratigraphic markers (5.3 Ma, 2.6 $\mathrm{Ma}, 0.9 \mathrm{Ma}$ and $0.45 \mathrm{Ma}$ ), the mapping of total sediment thickness and the determination of overall sedimentary volumes enabled us to provide a high-resolution quantitative history of sediment volumes for the last $6 \mathrm{Ma}$ along the Gulf of Lions margin. The results point to (i) a dramatic increase in terrigenous sediment input during the Messinian Salinity Crisis. This increased sedimentation reflects enhanced regional fluvial erosion related to the dramatic fall of Mediterranean base-level. Stronger weathering due to a regional wetter climate probably also increased erosional fluxes. (ii) A sediment input three times higher during the Plio-Quaternary compared to the Miocene seems in agreement with published measurements from World's ocean. However, the timing of this increase being uncertain, it implies that the trigger(s) also remain(s) uncertain. (iii) A decrease in detrital volume around 2.6 Ma is attributed to a regional change in the drainage pattern of rivers in the northwestern Alps. (iv) This study also highlights the Mid-Pleistocene Revolution around $0.9 \mathrm{Ma}$, which resulted in an almost doubling of sediment input in the Provencal Basin.
\end{abstract}




\section{INTRODUCTION}

The large worldwide increase in denudation rates during the Pliocene-Quaternary has been evidenced by sedimentary records in a variety of settings (Hay et al., 1988; Molnar and England, 1990; Hay et al., 2002; Kuhlemann et al., 2002). This major increase is suggested to start in the late Messinian (5.5 Ma) and accelerates towards present day (e.g. Zhang et al., 2001; Molnar, 2004; Herman et al., 2013). Those studies present compelling evidence that enhanced climate variability beginning in the Late Cenozoic has continually destabilized landscapes and led to increased erosion in upland environments. However, the effect of cooling on global erosion rates remains unclear. The uncertainty arises mainly from a lack of consensus on the use of the sedimentary record as a proxy for erosion and the difficulty of isolating and quantifying the respective contributions of tectonics and climate on erosion (e.g. Herman et al., 2013).

Quantification of erosion rates are typically interpreted from exhumation rates obtained by provided by lowtemperature thermochronological analyses of crystalline rocks exposed in mountainous regions, or by sedimentary budget studies of the sedimentary rocks of the adjacent sedimentary basin (Baran et al., 2014). However, Willenbring and von Blanckenburg (2010) have challenged the validity of sediment budget records, based on aliasing effects. Sediment-flux studies would be inherently flawed because of the Sadler effect (Sadler, 1981; Schumer and Jerolmak, 2009, Willenbring and von Blanckenburg, 2010), i.e. an apparent increase in sediment fluxes toward the present because sedimentary hiatuses are poorly dated and often ignored altogether in older sediments due to increasingly inaccurate and imprecise chronologies.

The Alps case study has played a prominent role in this debate. As with many mountain belts worldwide, the Alps have undergone a large increase in sediment yield in the late Neogene. Sediment budget calculations suggest a more than twofold increase in erosion rates since ca. 5 Ma (Kuhlemann, 2000; Kuhlemann et al., 2001) coeval with regional climate change and backstepping of the active deformation front (e.g. Willett et al., 2006). This suggests the occurrence of a series of climatic changes that increased erosion rates, even as tectonic processes appear to have slowed or stopped. At present, tight correlations in time are difficult to establish and open questions remain about the role of tectonics in the coupled system (Willett, 2010).

Available detrital thermochronological data from Alpine foreland also imply unchanged orogen-wide exhumation rates from Miocene to Pliocene time (Bernet et al., 2001; Glotzbach et al., 2011a), apparently contradicting these sediment budget calculations. But other regional-scale studies (Vernon et al., 2008; Herman et al., 2013; Fox et al., 2015b) show that exhumation rates in the Western Alps have increased since Late Miocene times. 
Moreover, although climate may influence denudation rates in the Alps, especially since the beginning of the Quaternary glacio-eustatic cycles, several authors have emphasized the importance of lithospheric-scale processes beneath the Alps, (e.g., Lyon-Caen and Molnar, 1989; Andeweg and Cloetingh, 1998; Kissling, 1993; Lippitsch et al., 2003; Genser et al., 2007; Sue et al., 2007; Kuhlemann, 2007; Wagner et al., 2010; Fox et al., 2015b). Denudation rates would correlate more satisfactorily with the surface uplift (Wittmann et al., 2007; Willett, 2010). Some of this may be isostatic rebound in response to rapid erosion (Champagnac et al., 2009, Vernant et al., 2013) or a deep geodynamic ("dynamic uplift") component (e.g. Calais et al., 2002; Serpelloni et al., 2013).

In this paper, we will focus on the quantitative evolution of sedimentation in the Provence Basin for the last 6 Ma and try to identify the main factors (at global, and regional scales) controlling this evolution in a source to sink approach. This basin is mainly fed by sediments from the Alps, we will thus discuss our results within the Alpine evolution context, along with uncertainties and limits of this sediment-based study.

\section{GENERAL SETTINGS}

The Mediterranean area is one of the most appealing natural laboratories in the world to study recent geodynamic and paleoclimatic processes. The Gulf of Lions continental margin and its prolongation with the Provencal basin in the Western Mediterranean (Fig.1) results from the Late Oligocene-Aquitanian rifting and later south-eastward drift of the Corsica-Sardinia block (Séranne, 1995). They are subject to strong post-rift subsidence (Réhault et al., 1984; Bessis, 1986; Burrus, 1989) and high sedimentation rates (mostly supplied by one major river, the Rhône), which facilitates high-resolution sedimentary studies. This area has been intensively explored for decades, providing a particularly large amount of seismic data (Fig.1) and detailed onland studies on its catchment (e.g. Kuhlemann, 2000; Kuhlemann et al., 2002; Willett, 2010). Hence, the Provence Basin is well-suited to study the detailed evolution of detrital budgets and to understand the climatic and/or tectonic events driving sedimentation.

The stratigraphy of the Gulf of Lions and the Provence Basin has been studied at variable timescales from synrift series (e.g. Gorini, 1993; Guennoc et al., 2000), Oligo-Miocene (Mauffret et al., 1995; Bache, 2008), Pliocene and Quaternary (e.g. Lofi et al., 2003; Droz et al., 2006; Rabineau et al., 2014) to the last 500 kyr (e.g. Rabineau et al., 2005; Bassetti et al., 2008) (see Fig. 2 for an example on the shelf). The data bases were sometimes limited and the stratigraphic continuity between the shelf and the basin is hampered by the presence of numerous canyons incising the upper slope (e.g. Baztan et al., 2005). This is why these studies have focused on specific areas of the margin (the shelf or the deep basin) and the correlation along the entire margin had never 
been completely elucidated for Pliocene to Quaternary times. As a consequence the detailed sedimentary budgets remained largely undefined until now. In this study, we therefore propose for the first time a high-time resolution quantification of sedimentation volumes across the entire basin margin during Miocene, Pliocene and Quaternary times.

Shortly after $6 \mathrm{Ma}$, the Mediterranean region underwent rapid and dramatic paleo-environmental changes known as the Messinian salinity crisis (MSC) (Hsü et al., 1973). This short-term event at the geological scale $(\sim 5.96-$ 5.32 Ma Krijgsman et al., 1999a) results from the progressive closure of the connection between the Atlantic Ocean and the Mediterranean sea (e.g. Benson et al., 1991; Ryan, 2011). Many previous studies have focused on particular aspects of the Messinian Salinity Crisis (MSC): the Messinian Erosional Surface (e.g. Gorini et al., 2005), salt tectonics (e.g. Dos Reis et al., 2005), eroded and deposited volumes (e.g. Lofi et al., 2005; Bache et al., 2009), or reflooding (Garcia-Castellanos et al., 2009; Estrada et al., 2011; Bache et al., 2012). In the Provence basin, two different interpretations for the base of the MSC (Lofi and Berné, 2008; Bache et al., 2009) result in two different estimates of the amount of detrital Messinian sediments. In this study, we also further examined the competing Messinian scenarios in the light of our new quantitative calculation of sediment volumes.

\section{MATERIAL AND METHODS}

\subsection{DATA}

For this study we used an extensive set of seismic reflection and drilling data available for the Provence Basin (Fig.1) and made available through the "Actions-Marges" program involving a consortium of institutions (CNRS, IFREMER, IFPEN, BRGM and TOTAL).

The seismic data can be subdivided into three groups according to their resolution and penetration characteristics: (i) the highest resolution Multi Channel Seismic (MCS) surveys (HR 80 and 81, MARION and CALMAR) allow detailed observations but provide little penetration; (ii) industrial seismic surveys performed since 1980 (LIGO, GL, MF, LRM, RM, SW, MDT, MAP, MEDS) and the seismic reflection data of the SARDINIA survey image the top of the sedimentary column to the base of the basin; (iii) the seismic survey ECORS (De Voogd et al., 1991) and the seismic survey refraction of SARDINIA provide deep penetration profiles throughout the crust. The wide-angle seismic data from Expanding Spread Profiles (ESP) (Le Douaran et al., 1984; Pascal et al., 1993) and Ocean Bottom Sismometers (OBS) (SARDINIA: Aslanian et al., 2012; Moulin et al., 2015; Afilhado et al., 2015) also allow to quantify the velocities and thicknesses of sediment series 
and the crust in the deep basin.

Nine petroleum wells drilled between 1969 and 1985 in the Gulf of Lions have been used to calibrate seismic interpretations. Seven of them are located on the shelf. Two others, Autan1 and GLP2, are located on the upper and mid-slope, respectively (Fig.1). Stratigraphic, sedimentological and micropaleontological studies (Cravatte et al., 1974) for the Autan, Mistral, Tramontane and Sirocco boreholes provide information on the depositional environments and chronostratigraphy of the drilled series.

\subsection{METHODS}

Several successive steps are needed for the quantification of detrital sediment volumes. First, the application of the seismic stratigraphy principles (Mitchum and Vail, 1977; Vail et al., 1977) allowed us to define stratigraphic discontinuities and remarkable stratigraphic surfaces on seismic profiles (Figs. 2-7 and Tab.1). Ages of these surfaces were provided by well data (Figs. 4, 5, 8) updated using the IUGS timescale for the Cenozoic (Gibbard et al., 2010). Our interpretations were then integrated into the "Kingdom Suite" software and mapped using GMT (Generic Mapping Tool) software (Wessel and Smith, 1995). Interpolated isobath and isopach grids (ms twtt) of each chronostratigraphic marker and unit were calculated. All these grids were built with the same resolution and geographical limits (resulting in the same number of nodes, see Figs. 9 and 10).

The seismic velocities vary strongly in space within the same stratigraphic interval, with important differences between the shelf, the slope and the deep basin. Therefore, the ESP velocities and wide-angle data from the Sardinia cruise in the basin and sonic logs of the drillings on the shelf were jointly analyzed and used to establish a 3D map of seismic velocities for each stratigraphic interval (Tab.2). The interpolation of these velocities with a regular and relatively restricted step (each $100 \mathrm{~ms}$ twtt) allowed us to avoid abrupt velocity transitions. We then depth converted isochore maps of all our stratigraphic units (Fig. 10a-c) and drawn all isopach maps in meters as shown in Leroux, 2012 (Fig. 10d-e). At this stage we calculated volumes for compacted sediments with GMT software (Tab. 4).

Afterwards we defined the proportion of dominant facies from wells and mean burial depths for each unit from seismic profiles. The wells are mainly located on the shelf, except GLP2 (on the slope), and are not representative to define a regional mean compaction law. We therefore built our law using the GLP2 borehole data and assuming that the sonic velocity roughly represents the porosity versus depth (a sonic log provides a formation interval transit time, which typically varies lithology and rock texture but particularly porosity). The sonic velocity curve images the evolution of the seismic velocities with depth of the sediment, including all 
lithologies, but the GLP2 well exhibits mainly shale facies. The superimposition of GLP2 sonic velocity curve fits the median curve of the compaction interval given by Allen and Allen's (2005) curves for shale (Fig.11). Assuming that this median curve can be used for the other lithologies (sand and carbonate) and that the decrease in volume is equal to the reduction of porosity, we estimated the porosity loss for each unit and calculated the compacted (zero porosity) and decompacted volumes. These volumes were finally assigned to a time-span and sediment fluxes were-calculated with their uncertainties using the numerical code of J. Braun (see Results section and Guillocheau et al., 2012 for more explanation).

\section{RESULTS}

\subsection{Seismic markers and their chronostratigraphic attribution}

The chronostratigraphic seismic markers and units are shown in Figures 2 to 8 and their main characteristics summarized in Tab.1 together with their chronostratigraphic correlation.

\subsubsection{Identification of Pliocene and Pleistocene seismic markers and units}

Very high resolution profiles interpreted in Rabineau (2001) and Rabineau et al. (2005) (Fig.2) showed that the last five erosional surfaces (D70, D60, D50, D40, D30) correspond to the last five glacial maxima of 100,000 yr cycles, with preservation of the shoreline on the outer shelf. The fifth surface D30 (also called Q5) was interpreted as MIS12.2 (Rabineau et al., 2006) and therefore dated at 434,000 yr, according to the orbitally tuned isotopic Specmap curve (Imbrie et al., 1984). This dating has been further validated by further direct dating on Promess borehole (Bassetti et al., 2008). Other erosional surfaces are evident below D30: surface Q10 (red on Fig.2) is a major erosional surface that lies around $450 \mathrm{~ms}$ (or $400 \mathrm{~m}$ after time-depth conversion) below present day sea-level and seals a strong incised unit on the outer shelf at around 60-64 km from the coast. The wellknown Messinian Erosional Surface (MES) (pink on Fig.2) is a prominent erosional surface at the base of the Pliocene series. Between the MES and the upper two surfaces (Q5 and Q10), the seismic profiles display a complex set of large prograding clinoforms (around $500 \mathrm{~m}$ high) with a typical topset-foreset-bottomset organisation (see the positions of the shelf-slope breaks and toeset breaks) and buried submarine canyons (Figs. 2 and 4). These clinoforms show a gently dipping linear topset and a highly dipping foreset curving more or less progressively to a gently dipping bottomset. Topsets are preserved through time and show an increased topsetslope with increasing age. On the shelf, Pliocene-Quaternary strata show a clear change in stacking pattern (shelf-slope breaks are indicated by black circles and shelf-edge trajectory is drawn by black line on Fig.2), from Late Pliocene prograding clinoforms to prograding-aggrading Quaternary clinoforms after another remarkable 
erosional surface (P11, yellow on Fig.2) (Leroux et al., 2014). On the shelf, this surface erosionally truncates the topset of earlier clinoforms (dark green and red clinoforms on Fig.2) and the first canyons occur above it (Figs. 2 and 4). A PXX discontinuity (blue on Fig.2 and Tab.1) is present between P11 and Q10 and corresponds to a major erosive surface on the slope.

Several prograding prisms are present on the shelf between the MES and P11. The oldest prisms downlap onto the MES (Figs. 2 and 4), the sediment are mostly trapped on the shelf until P7 marker (brown on Fig.2) which is the first Pliocene surface that can be prolonged onto the upper slope and down to the basin.

Pliocene and Pleistocene reflectors can be followed from the shelf to the basin, even if their seismic amplitude may vary laterally (Figs. 6 and 7). The proximal to distal spatial distribution of sediments for the last 5.3 Myr is strongly controlled by the front of salt tectonics linked to the halite unit deposited during the MSC (Figs. 6 and 7). From undeformed upstream of the front (km 110 on Fig.7), they are affected by listric faults downstream and pinch out on the footslope. In the basin (downstream of ESP207 on Fig.6), salt diapirs strongly disrupt the tabular stacking of Pliocene and Pleistocene sediments and reach locally the seafloor.

\subsubsection{Identification of seismic markers and units of the Messinian Salinity Crisis (MSC)}

On the shelf, the rough topography of the MES (Fig. 2, 3) results from incision of the Messinian fluvial network due to a major sea-level fall exceeding $1500 \mathrm{~m}$ (e.g. Ryan and Cita, 1978). The pre-Messinian shelf deposits were exposed to major erosion at that time, with very limited Messinian fluvial deposits occurring on the shelf. The MES can be followed from the shelf to the slope. At around $80 \mathrm{~km}$ from the present day coast the surface branches into two surfaces (Fig.3) with a Basal Erosional Surface truncating Miocene deposits identified as BES using the terminology defined in Lofi et al. (2011).

This surface has been interpreted as the base of the MSC that correlates seaward to a conformable surface called Basal Surface (BS) or the MES-CC* (MES Correlative Conformity) in Gorini et al., 2015 above which is described (from bottom to top) the Messinian trilogy in the deepest basin: (i) the Lower Unit (LU) is identified by a group of continuous high amplitude reflections. At the present time, the age, lithology and depositional environment are still speculative but Lofi et al. (2005) proposed that LU deposited in a fully subaqueous environment and may contain a large part of sediments eroded from the margins at the beginning of the drawdown and accumulated as giant turbidites above the abyssal plain. (ii) the Mobile Unit (MU) corresponds to a thick layer of transparent seismic facies associated to a homogeneous salt layer (halite); it is overlain by (iii) 
the Upper Unit (UU), that is identified by a group of parallel and relatively continuous reflections of relatively high amplitude. Its top has been sampled during DSDP Leg XII (Hsü et al.,1973), revealing layers of dolomitic marls and anhydrite.

A competing interpretation from Bache et al. $(2009,2012)$ described a much deeper discordance corresponding to the base of the MSC (Bache_BES). Above this latter, the authors identified an earlier (below Lofi_LU) thick (up to $1000 \mathrm{~m}$ ) terrigenous (turbiditic) serie (Bache_M1) and ascribe it to the subaerial erosion linked to the MSC drawdown. It would therefore correspond to a major sediment transfer, which built detrital wedges of thickness as much as $1000 \mathrm{~m}$ at the outlet of the Messinian Rivers, and in the order of $800 \mathrm{~m}$ in the basin. In contrast, Lofi and Berné (2008) attributed this unit to submarine slope erosional canyons that pre-date the initiation of the MSC. Bache_M1 is partly prolonged in the distal part of the margin by a thick (up to $800 \mathrm{~m}$ ) unit (Bache_LU0) of probably deep marine deposits; a thick $(1500 \mathrm{~m})$ presumed alternation of terrigenous and evaporitic deposits (Bache_LU1) overlies Bache_LU0 below the MU (Fig.3). Gorini et al. (2015) recently imaged Messinian dual lowstand megasequences of both the eastern and western Mediterranean agreeing with the position of the base of MSC from Bache et al. $(2009,2012)$. This implies that the total thickness of Messinian deposits in the basin, including LU0, LU1, MU \& UU), would be as much as $3500 \mathrm{~m}$. So, in the two competing interpretations, the respective sediment volumes related to MSC will strongly differ.

Bache et al. $(2009,2012)$ distinguished also a chaotic sub-unit overlying Bache_M1 on the slope and interpreted it as late detrital products of the MSC (Bache_M2). A smooth and straight surface at its top is also observed on the slope, in the prolongation of the rough MES on the shelf. It is locally either conformable with the underlying pre-crisis series or erosional as it truncates the underlying syn-crisis series. This surface, called RS (ravinement surface), would be the result of a transgressive ravinement during a first relatively slow refilling at the end of the MSC (Bache et al., 2012) but prior to the very drastic increase of sea-level suddenly drowning the Mediterranean Sea and preserving the rough morphology of the MES (Figs. 6 and 7).

In this study, we identified and mapped a new unit on the slope of the Gulf of Lions that (also described in Bache et al. (2015)). It is located either above Bache_M2 unit from which it is distinguished by a chaotic and more transparent seismic facies or in lateral correlation with MU and UU (Tab.1). Given its stratigraphic position, we called it M3. In the next section, informations from borehole data will be detailed to show how we can integrate this unit in the scenario of the MSC.

\subsubsection{Attribution of ages from borehole data and previous works}


The dating of Q5 at 434,000 years (Rabineau et al., 2006) is now fully confirmed thanks to multiproxy analysis of the sedimentary succession of the two PROMESS drillsites (PRGL1 and PRGL2). Indeed, chronostratigraphy established by estimates of the abundance of biostratigraphically significant coccolith taxa and correlations with the ${ }^{18} \mathrm{O}$ isotopic curve (Bassetti et al., 2008; Sierro et al., 2009) is coherent with previous stratigraphic modelling (Rabineau et al., 2005).

Older remarkable erosional discontinuities were observed on the Pliocene and Quaternary shelf, in particular Q10, P11 and P7. Ages of 0.9 Ma, 2.6 Ma and 3.8 Ma, were respectively suggested for them (Rabineau, 2001) by extrapolation of Q5 dating to older series taking into account the sediment thicknesses on the shelf and tilting of erosional surfaces as subsidence was shown to be constant through time during the entire Pliocene and Quaternary (Leroux et al., 2014; Rabineau et al., 2014). (Tab.1 and Fig.2).

In the Autan 1 well (Fig.4) the Q10 discontinuity is included in an unit younger than 1.8 Ma (Cravatte et al., 1974). In the same well, the position of the P11 discontinuity corresponds to the appearance of Neogloboquadrina atlantica. This planktonic foraminifer species lived around 11 Ma during a first short timespan, but showed large specimens. This same species, but with a much smaller size and sinistral coiling, appeared again between 2.72 Ma and 2.41 Ma (Lourens et al., 2004), so that it is used to detect the base of the Gelasian (2.588 Ma), i.e. of the Quaternary as defined by Gibbard et al. (2010) in marine environments (Suc et. al, 1992). P11 is therefore consistency dated at about 2.6 Ma within this well.

The surface PXX fits with a seismic marker previously interpreted on the slope and all over the area by Dos Reis (2001). This reflector was dated around 1.6 Ma-1.8 Ma by this author (it was identified in borehole GLP2 as the Pliocene-Quaternary transition using the definition at that time, i.e. at 1.8 Ma). This age is consistent with the chronostratigraphy proposed by Rabineau (2001).

A rough estimate using thicknesses of Pliocene and Pleistocene series suggested a date around 3.8 Ma for P7 (Rabineau et al., 2014) in concordance with the age estimated from biostratigraphic data (3.6 Ma-3.8 Ma in Lofi et al., 2003). In the well Autan1, the surface P7 corresponds to the top of the Lower Pliocene as defined by Cravatte et al. (1974) at the extinction level of Globorotalia puncticulata (3.57 Ma: Lourens et al., 2004). This age is close to a major climatic change marked by the appearance of the Mediterranean climatic rhythm (summer drought) causing the individualization of the modern Mediterranean floral elements (Cravatte and Suc, 1981; Suc, 1984; Suc et al., 1992). This event is precisely dated at 3.37 Ma in the Black Sea (Popescu et al., 2010).

The MES is a diachronous surface that results from erosion and incision of the Messinian fluvial network during the MSC. The end of the crisis is astronomically dated at 5.33 Ma according to the GSSP of the Lower Pliocene 
Zanclean Stage (Van Couvering et al, 2000). Most authors therefore agreed to date the end of the Salinity crisis at 5.33 Ma (CIESM, 2008) although some studies suggested that reflooding preceded the base of the Zanclean (Cavazza and DeCelles, 1998; Carnevale et al., 2006) and took place before the GSSP, at $5.46 \mathrm{Ma}$ (Bache et al., 2012). Given that sedimentation rates estimates will not change significantly between these both ages (they will remain within error bars), in this study we will use the consensual value of 5.33 Ma for the end of the crisis.

At present, no definitive data are available for the timing of initiation of the deep basin Lower Unit (LU), the massive salt (MU) and the base of Upper Unit (UU), as no drilling has sampled these layers. In this paper, we will consider the beginning of the crisis at $5.96 \mathrm{Ma}$, which is the age of lower evaporites in peripheric basins (Krijgsman et al., 1999a).

Above the BES (base of the Messinian), Autan 1 shows a thick unit (500 m) comprising two sub-units: sandy marls and carbonated clays (Fig.5). The first sub-unit may correspond to the early Messinian detrital unit (LU0) according to Bache et al. (2012). The GLP2 well shows a heterogeneous lithology at depths corresponding to the M3 unit (between 3385 and $3703 \mathrm{~m}$ bsf). The top of this interval is characterized by a 52-m thick alternation of sands and clays. Below, the unit consists of an alternation of halite, clays and anhydrite. Moreover, the thin clayey layers contains $80 \%$ of planktonic foraminifera (Brun et al, 1984), testifying to marine inflows into the basin. Laterally, on both sides of GLP2, M3 seems to directly overlie either unit M2 or unit LU. The stratigraphic connections of M3 with other Messinian units (Tab.1), its position on top of the abrasion surface (Fig.10b) and its microfossil content, suggest that it corresponds to a terminal deposit of the MSC in marine condition. The M3 unit is always located downstream from the limit between the MES and the RS (Fig. 10b).This limit is interpreted as the position of the shoreline at the end of a first slow step of reflooding (Bache et al., 2012). M3 unit can therefore be interpreted as a late product of the MSC, related to reflooding; its sandy facies would result from marine abrasion by waves (Bache et al., 2012).

We also checked the stratigraphic position of the MES from the seismic data in the wells and the reconstruction of depositional environments deduced from Cravatte et al. (1974), based on detailed biostratigraphic analyses (planktonic and benthic foraminiferas and calcareous nannoplankton). Autan1 shows a slight transgressive trend below the MES which might be related to the first step of a slow sea-level rise as suggested by Bache et al. (2012). Depositional environments deduced from micropaleontological analyses by Cravatte et al. (1974) indicate a transgressive trend during the Late Oligocene - Early Miocene with a maximum flooding that may correspond to the Miocene Climatic Optimum in the Late Burdigalian-Early Langhian or to the maximum 
flooding surface predating the Tortonian sea-level fall at about $12 \mathrm{Ma}$ (Haq and Schutter, 2008). It is followed by a regressive trend during the Late Miocene, including the Messinian, and an abrupt increase in depth in the Early Pliocene. This pattern is the same for all wells (although it cannot be established for Siroccol due to lack of data), which gives consistency to the overall interpretation.

The entire shelf underwent intense erosion during the MSC so that none of wells on the platform shows MSC deposits. Only Autan1, located on the upper slope, shows a regressive trend above the base of the MSC from Bache et al., 2009 (Fig.8). This interval corresponds to a mega-forced regression also described in Gorini et al., 2015 which would be the result of instabilities triggered by rapid sea level drop. These deposits would derive from the cannibalization of the Miocene margin as shown by the presence of Serravallian and Langhian faunas (Cravatte et al., 1974). Miocene margin exhibit also a particularly carbonate-rich content, as shown on the Cicindele well that is located on the inner shelf (Fig.5). Its dismantling and the downstream transfert of precrisis sediments during the MSC therefore explains the high carbonate content of the regressive sequence observed above the base of the Bachees MSC on Autan 1. This leads us to favour the base of the MSC as pointed by Bache et al. (2012).

Finally, the older remarkable surface we picked is the top of the basement (brown on Figs. 2,4,5,6,7). It seals a highly reflective and chaotic seismic facies on seismic profiles and corresponds to the top of Mesozoic sediments (Bache et al., 2010). Rifting in the Gulf of Lions occurred during Chattian and Aquitanian times (between $30 \mathrm{Ma}$ and $20 \mathrm{Ma}$ ) but the age of the end of rifting is not very well constrained (20 $\pm 3 \mathrm{Ma}$ according to different authors such as Séranne (1999), Speranza et al.(2002), Ferrandini et al.(2003) and Gattacceca (2007). The Basement is thus mainly overlain by the Oligocene/Miocene post-rift sedimentary cover. Since the syn-rift deposits are very thin (Bache et al., 2010), we considered this surface as the base of the post-rift sedimentation dated around $23 \mathrm{Ma}$. A global pre-MSC sediment volume will be quantified from the top of the basement to the base of the MSC and a mean sedimentation rate will be calculated for the pre-MSC interval.

\subsection{Isobath and isopach maps}

The comparison between the sea-floor topographic map deduced from this study and the bathymetric map drawn from multibeam echosounder data (Fig.9) shows the high spatial resolution of this study.

We computed isochron maps of all stratigraphic markers and isopach maps (in ms twtt) of all seismic units defined previously for the Pliocene-Pleistocene and the Miocene (Figs. 10a-b). Thickness maps (in ms twtt) of 
the entire sedimentary cover and for each period (Oligo-Miocene, Messinian, Pliocene and Pleistocene) are drawn in Fig.10c and depth-converted thickness maps are provided in Figs. 10d-e.

Oligo-Miocene sediments are preferentially deposited into basement depressions, such as in the Central Graben (where more than $2000 \mathrm{~ms}$ twtt of sediments are observed) and in its South-Easternward prolongation (Fig. 10c) while high reliefs of basement (where accommodation is reduced) correspond to weak sedimentation areas (less than $750 \mathrm{~ms}$ twtt). The morphology of the basement strongly constrains the Oligo-Miocene sediment dynamics. The comparison between Oligocene-Miocene and Pliocene-Pleistocene maps (Fig.10c) shows an eastward migration of depocenters. As the half South-West of the Gulf of Lion is characterized by many basement depressions, it received most sediment during Oligo-Miocene. Very weak thickness of Miocene deposits (less than $300 \mathrm{~ms}$ twtt) on the Eastern shelf suggests that subsidence is here delayed relative to western shelf. Miocene subsidence did not create enough space for sedimentation, the Eastern margin being stayed in a high position (Bache et al., 2010) probably for a longer time. From thickness map of Oligo-Miocene deposits, we infer also the possible location of a proteo-"Rhone" during Oligo-Miocene as indicated in the Fig.10c. Basement depressions on the Eastern (rhodanian) side of the margin will not be filled before Pliocene and Pleistocene. The canyons incisions and sedimentation on the slope at that time are also particularly notable.

Pliocene deposits (top-bounded by P11 reflector) on the slope are relatively thin (compare last maps on Fig.10d) with a maximum thickness of about $700 \mathrm{~m}$, and the P11 surface locally erodes down to the top of Messinian. Conversely, Quaternary deposits are there very thick (mean thickness of about $1500 \mathrm{~m}$ ) and particularly the last 500 ka between Q5 (or D30) and the present-day sea-floor (Fig.10d). The development of Quaternary submarine canyons (and axial incision) implies thicker deposits on the interfluves.

\subsection{Corrections for porosity}

The proportion of dominant facies (established from wells, cf Fig. 5) and mean burial depths for each unit (from seismic profiles) have been defined (Tab.4). Using porosity versus depth curves from Allen \& Allen (2005) we then determined initial and final porosities readable on the median curve centred within the compaction interval (red curves on Fig.11). This allows us to calculate initial volumes (porous volumes) derived from sediment volumes calculated from our isopach maps. Assuming that the decrease in volumes is equal to the reduction of porosity, we were able to decompact or compact (zero porosity) the volumes for all units (Tab.4). These volumes were finally assigned to a time-span in order to calculate both decompacted and solid (i.e. for zero porosity) sediment volumes (Tab.4 and Fig.13). 


\subsection{Resolution and source of uncertainties}

Numerous uncertainties are associated with the quantification of detrital volumes. These uncertainties result from: (i) seismic resolution, (ii) depth conversion of TWTT, (iii) the determination of terrigenous versus intrabasinal sediment fractions, (iv) the assumptions used during the decompaction procedure, (v) the chronostratigraphic estimates of our seismic markers.

In order to assess the uncertainties for each time interval, we used five regional dip-sections, which were compiled to represent the variability of the stratigraphic architecture of the basin (Fig.12). Based on an interpolation between these sections, we calculated the volume of sediments accumulated in the basin for each time interval and determined variances associated with each parameter using a statistical approach implemented in the numerical code developed by Jean Braun (See Guillocheau et al., 2012 for more explanation). The code considers the uncertainties on (i) seismic velocities for the depth conversion (10\%), (ii) absolute ages of stratigraphic horizons (varying between 0 for Q5, around $0.1 \mathrm{Ma}-0.5 \mathrm{Ma}$ for the other Plio-Pleistocene markers and $3 \mathrm{Ma}$ for the basement), (iii) carbonate content (varying from $0 \%$ to $50 \%$ in the different time intervals), and (iv) remaining porosities. Because detailed lithologies are too variable to be adequately described at the basin scale (they are only known on the platform), we assumed a constant sand/shale ratio within each time interval. We then tested a wide range of sand/shale ratios (ranging from pure sand to pure clay) and estimated the influence of this sand/shale ratio in the estimation of the accumulated volumes.

\subsection{Quantification of the terrigenous sediment volumes}

Estimated solid sediment volumes in the Gulf of Lions and Provence Basin over the last 20 Myr (Fig.13) developed as follows:

(i) relatively low sediment yield $\left(<2,000 \mathrm{~km}^{3} / \mathrm{Myr}\right.$ ) during the pre-Messinian Miocene (from $23 \mathrm{Ma}$ to $5.96 \mathrm{Ma}$ ); the uncertainties on the absolute age of rifting $(20 \mathrm{Ma} \pm 3 \mathrm{Ma})$ do not significantly change this trend.

(ii) a Messinian peak of detrital input (rates higher than $28,000 \mathrm{~km}^{3} / \mathrm{Myr}$ from $5.96 \mathrm{Ma}$ to $5.33 \mathrm{Ma}$ in the scenario of Bache et al, 2009; the associated uncertainties in this time interval reach almost $50 \%$ due to the unknown evaporitic part of the deposits (we have considered up to $50 \%$ of evaporites both in the early Messinian detrital unit and within the LU1 unit). Regardless of uncertainties, the Messinian peak of detritus remains. In the case of the scenario of Lofi and Berné (2008), we observe a clear peak, only if the LU1 contains at least $50 \%$ of terrestrial sediments. This point will be tackled in the discussion, in which we will also try to distinguish 
between terrestrial sources and recycled shelf material.

(iii) a sedimentary input of around $7,000 \mathrm{~km}^{3} / \mathrm{Myr}$ during the Pliocene (from 5.33 to $2.6 \mathrm{Ma}$ ) which is approximately four times higher than the Miocene mean rate. This trend is robust despite the uncertainties.

(iv) a decrease in the sediment volume in the Early Pleistocene (from 2.6 to $1.6 \mathrm{Ma}$ ) is also indicated despite the uncertainties. This decrease seems to carry on until 0.9 Ma.

(v) the sediment flux for the last $0.9 \mathrm{Myr}$ is more than double compared to the flux between 1.6 and $0.9 \mathrm{Ma}$.

(Note here that the uncertainty in the absolute age of the youngest time interval is null)

\section{DISCUSSION}

\subsection{ARE OUR ESTIMATES OF MESSINIAN DETRITAL VOLUMES DISCRIMINATING FOR THE IDENTIFICATION OF THE BASE OF THE MSC?}

Estimating a minimum detrital volume that should be found in the Messinian sediments is one way to discriminate between the two competing models for the base of the MSC.

Rivers respond to a drop in their base level by incising the topography. Messinian incisions are very deep in the downstream part of the valleys (more than 1,000 $\mathrm{m}$ for the Rhône) and have propagated very far inland (over 400 $\mathrm{km}$; Clauzon, 1982). According to Loget et al. (2006), the corresponding incision rate is up to $10 \mathrm{~mm} / \mathrm{yr}$ in the downstream part of the Rhône, i.e. similar to fluvial incision rates in tectonically active mountain belts such as the Himalayas (2-12 mm/yr, e.g. Burbank et al., 1996). The upstream propagation of an incision, as usually depicted by a knickpoint migration, is thought to depend on several parameters such as the drainage area, lithology, and the amplitude of the base level drop (e.g. Loget et al., 2009). Here, the exceptional kilometer-scale sea-level fall associated with a large drainage area also seems to have reached very high fluvial erosional rates. The erosion created two main incised valleys onshore: (1) to the East, the first one corresponds to the Rhône system together with a network from the region of Montpellier, both joining downstream into a single valley (Clauzon, 1982). (2) The other to the West corresponds to the Orb-Hérault system with headwards extending from the Languedoc and Roussillon region (Clauzon et al., 2015). A smaller incised valley to the South-West corresponds to the Têt-Tech system. Assuming a downstream limit of these incisions that corresponds to the present-day coast-line and a mean denudation thickness up to $50 \mathrm{~m}$ (estimated from the Pliocene abandonment surface), the isobath map of the MES onland allows calculating the onshore volume incised by these two main valleys. They are respectively estimated to $1500 \mathrm{~km}^{3}$ and $400 \mathrm{~km}^{3}$ (Clauzon et al., 2015). The recycled shelf material has been estimated to $\sim 3,000 \mathrm{~km}^{3}$ in the Languedoc and Roussillon areas (Mauffret et al., 2001 ; Lofi et 
al., 2005) and extrapolated to $\sim 10,000 \mathrm{~km}^{3}$ in the whole Rhône Valley and on the entire shelf of the Gulf of Lions where the MES has been observed $\left(>20,000 \mathrm{~km}^{2}\right)$ (Bache et al., 2009). The incisions do not end at presentday shelf-break, but occurred also on the slope. This latter volume, hardly quantifiable, is not included in this estimate. Finally, this volume does not take into account the direct input from the Rhône River. Considering a Messinian Rhône sediment supply similar to that of the Miocene Rhône $\left(\sim 3000 \mathrm{~km}^{3} / \mathrm{Myr}\right)$, around $2000 \mathrm{~km}^{3}$ of terrestrial sources sediments should have been discharged during the MSC (630,000 yrs). At least $14,000 \mathrm{~km}^{3}$ of sediments are thus eroded, transported and deposited into the basin during the MSC.

The two competing interpretations for the base of the MSC (Lofi \& Berné, 2008; Bache et al., 2009) (see section 3.11 ) result in two different estimates of the amount of detrital Messinian sediments (Fig.14). Given that the seismic facies in Lofi_LU (corresponding to Bache_LU1) suggests a significant evaporitic part that is unfortunately still unknown, three cases are considered with respect to its potential (compacted) detrital fraction: $0 \%$ (black), 20\% (dark grey) or 50\% (light grey). Total amount of detrital units (terrestrial sources and recycled shelf material are undifferentiated here) are thus displayed for each interpretation; for Lofi and Berné (2008) hypothesis, estimates include the fully detrital volume of the Clastic Unit (CU) and the potential detrital part in the Lower Unit (LU), whereas in the Bache et al. (2009) hypothesis, estimates include the fully detrital volumes of units LU0, M2, M3 and the potential detrital part in the Lower Unit 1 (LU1).

If we consider a fully evaporitic Lofi_LU, sediment flux story in Lofi and Berné (2008) $)^{\text {ee }}$ interpretation shows a slight decrease between Miocene and Messinian times (1900 km³/Myr), while Bache et al.(2009) 's interpretation implies a major detrital peak during the Messinian $\left(19,754 \mathrm{~km}^{3}\right)$. Since the strong amount of recycled clastics during the MSC (at least 10,000 $\mathrm{km}^{3}$ ), we attempt to observe a detrital peak related to the crisis (red bar on Fig. 14). In this case, Bache et al (2009) ${ }^{e e}$ interpretation appears to be more consistent.

For the 20\% hypothesis, Messinian detrital volume in Lofi and Berné (2008) 's interpretation only reaches 5,000 $\mathrm{km}^{3}$. This value is half that the minimum recycled volume from Miocene shelf and Rhone valley drawn in red bar in Fig. 14 (10,000 $\mathrm{km}^{3}$ from Bache et al., 2009). This hypothesis is thus not conceivable.

For the 50\% hypothesis, Messinian detrital volume in Lofi and Berné (2008)ees interpretation show a clear peak that hardly reaches $10,000 \mathrm{~km}^{3}$. This value corresponds to the minimum volume of recycled material from Miocene shelf and Rhone valley and implies that only re-deposition occurred during MSC, what appears unlikely.

To conclude, estimates of recycled and terrestrial clastics volumes related to the MSC do not allow favouring a scenario (and its corresponding position of the base of the event). As long as the detrital fraction of LU is not 
quantified in detail, both Bache et al. (2012) and Lofi and Berné (2008)'s interpretations remain possible. However, the latter (with a higher position for the base of the MSC) can be excluded if LU contains less than $50 \%$ of reworked detrital sediments.

\subsection{FROM OFFSHORE SEDIMENT BUDGET TO ONSHORE ALPINE DENUDATION RATES}

A few limitations prevent a straightforward correlation between our sediment budgets from offshore sedimentation to erosion patterns of the catchment area (in particular Alpine denudation rate). Closure of the system, onshore trapped sediments, change in drainage area, reworked material, dissolved part and Sadler effect are discussed below.

(i) To be relevant, our estimates from marine sedimentation (extension in thick black line on Fig. 15) need to capture most of the deposits from the catchment area (in yellow on Fig.15). A dip line-drawing (located in red on

Fig.15) displays the sedimentary architecture through the Provençal basin and the Sardinian margin. The Gulf of Lions margin exhibits thicker deposits relative to the Sardinian margin that is fed by smaller rivers. The Rhône River is $816 \mathrm{~km}$ long and has the second largest drainage area $\left(98,800 \mathrm{~km}^{2}\right)$ in the Mediterranean Sea (Pont et al., 2002). Its watershed includes a lot of mountainous environments such as the Alps, Massif Central, and Jura. Most of the offshore sediments originate from the Rhone River which transports Alpine sediments into the Gulf of Lions, compared to smaller inputs from the smaller Pyreneo-Languedocian rivers which mainly drain the Pyrenees (Aloisi, 1986). The Petit-Rhône Fan is the largest turbidite system in the Gulf of Lions. Situated in the central part of the gulf, it represents an accumulation of 3,600 $\mathrm{m}$ of turbidites and mass-transport deposits, mainly fed by alpine inputs through the Rhône River and Delta and the Petit- Rhône Canyon (Droz et al., 2006). These Quaternary sedimentary systems (dotted black lines on Fig. 15) are superimposed with our Pleistocene thickness map (thickest deposits are here in red) showing that our study integrates almost all these features. Our budget forgets the distal lobes of the Petit Rhone fan but their thicknesses appear negligible compared to the proximal channel-levee systems. Note that the Valencia fan is mainly fed by the Ebro River through the Valencia Basin.

(ii) Size of catchment areas and sediment pathways from source to sink changed through time. This spatial evolution need to be constrained to correctly correlate our sediment budget from sink with spatial denudation rate at the source. As argued by Kuhlemann (2000), a partitioning between debris from the Eastern Alps and the Swiss and Western Alps is attempted on the base of the varying catchment size. 
(iii) Our volume estimates take into consideration only marine sedimentation. They do not include the sediment volume that is trapped onshore, upstream of the studied marine sedimentary basin. So, they must be considered as minimum values, especially if we want to compare them to erosion rate in the onshore drainage area. This is especially significant during the Miocene when significant sediments traps existed in the foreland basins (Kuhlemann, 2000) and in the Zanclean rias between 5.46 and 4.5 Ma (Suc and Drivaliari, 1991; Suc et al., 1999; Bache et al., 2012) (pink on Fig. 15). At present day, the Rhône catchment drainage area includes the Valence basin, the Bresse graben and a part of the Molasse basin (Fig.15). The accumulation in the RhôneBresse graben, lasting from early Oligocene to recent times, reaches about $21,000 \mathrm{~km}^{3}$ in which less than $5 \%$ is of non-alpine origin according to Hay et al. (1992). 2,600 $\mathrm{km}^{3}$ of the bulk volume were deposited in Pliocene and early Pleistocene times. Post Messinian redepositions of sediments from Swiss and French Molassic basins account also respectively for about 2,200 km3 and 4,000 $\mathrm{km}^{3}$ (Kuhlemann, 2000). It means that considering only marine sedimentation minimizes absolute Pliocene and Quaternary erosion rates in the Gulf of Lions drainage area of at least $25 \%$.

(iv) On the other hand, our measured detrital volumes include recycled sediments. The reworking of Miocene sediments from the shelf is particularly important during the MSC. A significant part of the quantified MSC volume corresponds to sediments eroded from mountain areas before the crisis. Denudation rates calculated from MSC volumes would therefore be over-estimated, whereas pre-crisis Miocene denudation rates would be underestimated. Using the geometry of the MES and the seismic Miocene markers, Bache et al. (2009) extrapolated the intervals removed by erosion on the Western shelf during the MSC. They estimated a minimal eroded volume of $\sim 4000 \mathrm{~km}^{3}$ for (compacted) Miocene series and $10,000 \mathrm{~km}^{3}$ for the entire shelf and Rhône valley. In this paper, we estimated a purely detrital volume deposited or remobilized during the MSC (including the LU0, M2 and M3 units and excluding possible detrital within LU1, MU and UU units) of around 19,750 $\mathrm{km}^{3}$ (Tab.4). Therefore, around $50 \%$ of this volume may actually corresponds to pre-MSC Miocene erosive processes and remobilization during the MSC. Thus, the compacted Miocene volume previously calculated (Fig.13 and Tab.4) can be fixed for this purpose: it actually reaches $39,434 \mathrm{~km}^{3}$ equivalent to sediment flux of $2315 \mathrm{~km}^{3} / \mathrm{Myr}$. So, sediment inputs during Pliocene are no more four times higher than those during Miocene but "only" three times. (v) Moreover, the measured volumes do not include the dissolved component of erosion, which also contributes to continental denudation rates by chemical weathering. The amount of material carried as dissolved load is typically much smaller than the suspended load though this is not always the case particularly when the available 
river flow is mostly harnessed for irrigation, industrial, etc. purposes. Today, dissolved load in the Rhône River represents $30 \%$ of the suspended load (Poulos and Collins, 2002) but this trend has likely changed over the past. (vi) Finally, as we mentioned in introduction, Willenbring \& von Blanckenburg (2010) argued that sedimentflux studies are inherently flawed because of the "Sadler effect" (Sadler, 1981; Sadler \& Strauss, 1990). Based on the ${ }^{10} \mathrm{Be} /{ }^{9} \mathrm{Be}$ ratios of Late Miocene to modern offshore deposits, they inferred a constant erosional mass flux and interpreted the increase sediment discharge between Miocene and Pliocene as an artefact of the age and selective preservation of sediments. However, the Western Mediterranean is a closed basin where the potential sediment erosion and relabeling is minimal. The Sadler effect is thus not important in our setting.

\subsection{SOME INSIGHT INTO THE REGIONAL OR GLOBAL CONTROLLING FACTORS}

The evolution of post-rift detrital sediment budget in the Gulf of Lions are summarized and placed in a chronostratigraphic framework for comparison with global and local climatic and tectonic events in Fig. 16. Is this evolution driven by climate change, tectonic component or both of them?

\subsubsection{A doubling of sediment budget around 1 Ma driven by a global climate forcing}

The Mid-Pleistocene Revolution is characterized by a major change in terrestrial climatic cyclicity: the obliquity forced (41 kyrs) climatic cycles, which were dominant during the Early Pleistocene, were progressively replaced by $100 \mathrm{kyr}$ climatic cycles with higher amplitudes. This cyclicity change occurred around 0.9-0.8 Ma in the Atlantic Ocean (Ruddiman et al., 1986), as also observed through pollen records in the Mediterranean region (Joannin et al., 2011; Popescu et al., 2010). It is also accompanied by a global increase in the ice volume (Muttoni et al., 2003, Head and Gibbard, 2005). A significant increase in relief amplitude in the European Alps is also measured (Champagnac et al., 2008; Herman et al., 2013) despite diminishing rates of convergence and deformation (Calais et al., 2002).

Thermochronologic data indicate that the upper Rhône Valley has deepened 1-1.5 km since the Mid-Pleistocene (Valla et al., 2011). The installation of the 100-ka cycles seems to induce dramatic incision of alpine valleys while high topographies were preserved (Haeuselmann et al., 2007; Valla et al., 2011). It implies a link between the onset of efficient glacial erosion in the European Alps and the transition to longer, colder glacial periods. Enhanced Quaternary erosion of the Alps and isostatic compensation of the removed mass would thus explain the significant increase in relief amplitude measured in the European Alps since $1 \mathrm{Ma}$ (Champagnac et al., 2007, 
Fox et al., 2015b). This Late Pleistocene onset of glacial carving is confirmed by Glotzbach et al. (2013) with thermochronological AFT and AHe data in the Mont-Blanc Massif, which experienced "[...] valley incision and the associated increase in relief at $0.9 \pm 0.8 \mathrm{Ma} "$

Besides, longer eustatic cycles with higher amplitudes imply that lowered sea-level allow fluvial systems to erode continental shelves.

So, the enhanced climate variability and alpine glaciation over the last $1 \mathrm{Myr}$ provide a privileged mechanism for explaining the increase of alpine erosion rates and the subsequent two-fold increase of sedimentation on the Gulf of Lion margin.

\subsubsection{A decrease of sediment yield around 2.6 Ma driven by a change in drainage area}

Climatic processes are involved in the increase of detrital sedimentation since the middle of the Pleistocene. The first glacial/interglacial cycles began around 2.6 Ma with an increase of ice in the Northern Hemisphere (Lear et al., 2000). The decrease of detrital sedimentation between 2.6 Ma and $1 \mathrm{Ma}$ in the Provence Basin could then appear paradoxical. But, at that time, the contribution of a part of the Rhine tributaries was cut off from the catchment area of the Provence Basin. Indeed, up to 2.6 Ma, a large part of the modern Upper Rhine network (Aar present-day catchment) draining the northwestern Alps, was flowing towards the Mediterranean through the Doubs, Saône and Rhône valleys (Boyer, 1885; de Lamothe, 1903; Zagwijn and Doppert, 1978; Zagwijn, 1989). Near after 2.6 Ma, the Aar-Doubs system, deflected into the Rhine graben, started to flow out the Rhine River towards the North Sea (Zagwijn and Doppert, 1978; Zagwijn, 1989; Petit, 1993; Petit et al., 1996). The capture of the Aar River by the Rhine River has been evidenced by a drastic change in heavy minerals spectrum into the Upper Rhine and Bresse graben (e.g. Berger et al., 2005) and dated using rodents (Chaline, 1984), molluscs (Puisségur, 1984) and pollen reconstruction of climate (Farjanel, 1985). Recently, Ziegler and Fraefel (2009) proposed that this capture occurred around 1.7 Ma. Without the Aar contribution, the size of the catchment area of the Gulf of Lions was reduced by $30 \%\left(160,000 \mathrm{~km}^{2}\right.$ during Pliocene vs. $125,000 \mathrm{~km}^{2}$ at present-day) (Fig.17): the discharge in the Gulf of Lions may be strongly reduced. We can infer that the decrease in sediment supply from these tributaries prevailed on the potential increase of erosion linked to climate change. This emphasizes the importance that a decrease in sediment flux could be controlled by a decrease in catchment size.

\subsubsection{Increasing sediment yield since Late Messinian}


This study shows a clear peak of sediment input in the Provence Basin related to the MSC during Late Messinian, followed by a three times increase of detrital sedimentation between the Miocene (before the MSC) and the Pliocene (5.33 Ma-2.6 Ma).

The Messinian salinity crisis is widely regarded as one of the most dramatic episodes of oceanic change of at least the past $20 \mathrm{Ma}$ (Hsü et al., 1973). Orogenic uplift closed the Betic corridor through Spain in the latest Tortonian/earliest Messinian (Wijermars, 1988), and severely constricted the Rifian corridor through Morocco in the Earliest Messinian (Krijgsman et al., 1999b). These tectonic processes obviously isolated the Mediterranean basin from the Atlantic Ocean (between 5.59 and $5.33 \mathrm{Ma}$ ), limiting their water exchange, and thus probably heralded the onset of the MSC (Krijgsman et al., 1999a). The exceptional kilometre-scale subsequent sea-level fall associated with a large drainage area led to high fluvial erosional rates. Moreover, as argued by Willet et al., (2006), this base-level fall would have triggered a late Messinian (5.8-5.33 Ma) climatic shift to warmer and wetter climate in the Mediterranean region (Fauquette et al., 2006) that would have induced weathering and an intensification of erosion in the Alps. This may explain that, between 6 and $4 \mathrm{Ma}$, the orogen record the strongest increase of fluxes (from about 11,500 $\mathrm{km}^{3} / \mathrm{Myr}$ to $19,000 \mathrm{~km}^{3} / \mathrm{Myr}$ ) (Kuhlemann, 2000) in its history (Hunziker et al., 1992; Kuhlemann and Kempf, 2002). At that time, the European Alps ceased outward expansion, and tectonic uplift and exhumation shifted into the inner part of the belt (Willet et al., 2006). During the Messinian, evidences of intense tectonic reorganization also occurred at a world-wide scale. Sudden spreading rate changes in the South-East Indian, Pacific-Antarctic, and Chile ridges have been related to a change in the absolute motion of the Pacific plate (Cox and Engebretson, 1985; Pollitz, 1986). This change corresponds to the magnetic anomaly C3A that is dated at 5.9 Ma (Cande et al., 1995; Wilson, 1993; Krijgsman et al., 1999a). Cloething et al. (1990) highlighted also major reorganizations of spreading direction and rate during the Pliocene along the entire Atlantic spreading system, possibly in conjunction with more global changes in plate motions. As already argued by Krijgsman et al. (1999a), we suggest that the synchronicity of these events favors the hypothesis of a dominantly tectonic origin for the MSC that may be seen as a consequence of a global plate reorganization.

Our results also highlight a three times increase of detrital sedimentation between the Miocene (before the MSC) and the Pliocene (5.33 Ma-2.6 Ma).

It has been proposed that mountainous erosion increased globally around $5 \mathrm{Ma}$ in response to global climate change (e.g. Hay et al., 1988; Zhang et al., 2001; Herman et al., 2013), mainly because this increase coincides 
with a cooling trend indicated by global isotopic data (e.g., Zachos et al., 2001). This temporal coincidence is also observed in the sediment yield from the Alps (Kuhlemann, 2000; Kuhlemann and Kempf, 2002). Given that this increase is not accompanied by tectonic convergence across the Alps during this time period (e.g. Schmid et al., 1996), many authors (Cederbom et al., 2004; Willett et al., 2006; Vernon et al., 2008) invoke a climate driver. Cederbom et al. (2004) correlated the acceleration of erosional rates in the Alps with the exhumation of the North Alpine Foreland Basin at 4.5 Ma, suggesting that this increase in erosion was a response to the onset of the Gulf Stream and the resulting wetter and more erosive climate over continental Europe. The net erosional unloading would have caused isostatic uplift of the foreland and increased exhumation rates in the Alps via flexural accommodation. According to Willet et al. (2006), the onset of acceleration in erosional flux was initiated in response to a lowered base level resulting from the Messinian salinity crisis and when a more humid climate also increased erosion in the Alps. This resulted in focused exhumation of the Penninic crystalline basement. Despite differences in the geodynamic concepts between these studies, both Willett et al. (2006) and Cederbom et al. (2004) agree for a climate control and emphasize far-reaching consequences for the development of the orogen.

In contrast, other authors proposed tectonic models that are capable of explaining erosion without any climate forcing. According to Schlunegger and Mosar (2011), the earliest Pliocene initiation of enhanced sediment discharge reflects the recycling of the Molasse units that occurred in response to a shift in the drainage direction of the Alpine rivers. This shift would be controlled by tectonic activity in the Cenozoic European Rift System. Other regional-scale tectonic processes may also have driven erosion, such as Eurasian slab unloading beneath the Western Alps, as suggested by Baran et al. (2014).

Deciphering between these hypotheses about tectonic or climatic forcing to explain increased sediment budget over the last 5 Myr needs to better constrain the timing and resolution of this evolution and to better correlate regional and global events.

The global benthic $\delta^{18} \mathrm{O}$ record (Lisiecki and Raymo, 2005) spanning the current Pliocene, Pleistocene and Holocene Epochs depicts a major change towards heavier values around $4 \mathrm{Ma}$, interpreted as reflecting the beginning of a cooling trend associated with the growth of major Northern Hemisphere ice caps superimposed on short-term obliquity-dominated glacial cycles (Shackleton, 1997). At 3.3 Ma a marked cooling event occurs during the Mammoth subchron (Prell, 1984; Keigwin, 1986). Approximately at this point the background values 
of the LR04-stacked $\delta^{18} \mathrm{O}$ record reach present-day values for the first time. It corresponds to a global climate change due to the extension of continental ices in the Northern Hemisphere (Suc, 1984; Lear et al., 2000; Zachos et al., 2001). The Early Pliocene was a relatively warm period, showing short-term and weak amplitudes of temperatures variations. Although climate proxies from both Pacific (Zachos et al., 2001) and the continental records (Cerling et al., 1997; Bruch et al., 2006) do suggest a cooling trend between the Late Miocene and the Pliocene, this climate shift was gradual rather than a discrete single event. So, as already noticed by Willett (2010) for the alpine sediment budget, the apparent sediment increase in the Provençal Basin at 5.3 Ma occurred too early to correspond exclusively to Pleistocene glaciation. However, since the P7 chronostratigraphic marker (estimated between 3.8 and 3.4 Ma) has not been extended to the deep basin (Figs.2B and 10a), it is not possible, at present, to highlight variations in sedimentary fluxes between the Early and the Late Pliocene (Fig.13). Thus, we could consider that the increase did not occurred around 5.3 Ma but later, coinciding with the first global cooling episode related to ice extension in the Northern Hemisphere, now precisely dated at 3.37 Ma in the Black Sea (Popescu et al., 2010). Such an hypothesis would imply relatively weak sedimentation rates in the offshore of the Gulf of Lions margin during early Pliocene while sea-level was high and the Pliocene rias trapped most of detrital sediments in the onshore part of the margin until at least 4.5 Ma (Suc and Drivaliari, 1991; Suc et al., 1999). It would be also consistent with increased sedimentation rates (from two to ten times) and grain sizes that were recorded at world-wide scale at 3-4 Myr (e.g. Zhang et al., 2001; Molnar, 2004).

In the Po Basin, a systematic increase in sediment yield appears in the both Northern and Southern of the Alps also during the late phase of the MSC and continues through the Pliocene (Willet et al., 2006). Besides, climate studies show that the warm, wet, postglacial climate initiated during Late Miocene would be actually persistent until the Early to Middle Pliocene (Fauquette et al., 1999; Fortelius et al., 2002) and could also explain or contribute to the strong sedimentation in the Early Pliocene in our study area as also proposed for the Po Basin by Willett et al. (2006).

By $5 \mathrm{Ma}$, a sustainable strong increase of erosion rates occurred in the Swiss and Western Alps and a much weaker increase is detected in the Eastern Alps somewhat later, which makes a regional tectonic trigger more reasonable than a climatic trigger (Kuhlemann, 2007). Besides, seismic velocities below the Western Alps and Western Swiss Alps suggest asthenospheric upwelling between the lithospheric root of the orogen and a cold sinking slab (Lippitsch et al., 2003), suggesting slab break-off (Davies and Von Blanckenburg, 1995). Simultaneous redirection of the Aare-Danube River, proposed by Schlunegger and Mosar (2011), may also be a superimposed regional driving factor that enhanced erosion rates at Early Pliocene. Erosion of the Molasse Basin 
started at the same time that the rivers originating from the Central Alps were deflected toward the Bresse Graben, which formed part of the European Cenozoic rift system. This change in the drainage direction decreased the distance to the marine base level by approximately $1,000 \mathrm{~km}$, which in turn decreased the average topographic elevation in the Molasse Basin by at least $200 \mathrm{~m}$. Isostatic adjustment to erosional unloading required ca. $1,000 \mathrm{~m}$ of erosion to account for this inferred topographic lowering. The contribution of 12,000$24,000 \mathrm{~km} 3$ of recycled Molasse would correspond approximately to the increase in Alpine sediment discharge at the Miocene-Pliocene boundary.

This emphasizes the interest of estimating evolution of sediment volumes for the Pliocene interval with better resolution. Determining intra-Pliocene seismic markers in the Provençal basin would be indubitably beneficial.

\section{CONCLUSIONS}

We identified, mapped and dated Pliocene and Pleistocene stratigraphic markers (2.6 Ma, 0.9 Ma and 0.45 Ma) in the seismic record of the Gulf of Lions and Provence Basin. We drew a physical stratigraphic continuity between the shelf domain and the deep basin and estimated the evolution of detrital sediment volumes over the last 6 Myr with high resolution. A terrigenous peak occurred during the Messinian Salinity Crisis, a regional event at the Mediterranean scale, which results from a global tectonics change. Increased sedimentation in the Provence Basin reflects regional enhanced fluvial erosion related to the dramatic fall of the base-level of the Mediterranean Sea. Stronger weathering due to a regional wetter climate probably also increased erosion and therefore fluxes. This sediment-study also highlights finer changes throughout the Pliocene and Pleistocene. We observe two increase of detritic sedimention, (i) the first one during Pliocene (between 5.3 and 2.6 Ma), (ii) the second one around 1 Ma and (iii) a decrease of detrital sediment fluxes around 2.6 Ma. We relate the increased signal at 1 Ma to the world-wide "Mid-Pleistocene Revolution" that induces a global increase in ice volume and a significant increase in the relief of the European Alps. This event is marked by a doubling of the detrital volume at $0.9 \mathrm{Ma}$ in the Provence Basin. We attribute the decrease of detrital volume around $2.6 \mathrm{Ma}$ in the Provence Basin to a regional change in the drainage pattern of rivers in the northwestern Alps. The contribution of the upper part of the Rhine tributaries was cut off from the catchment area of the Provence Basin. The Pliocene and Pleistocene sedimentation appears to be more than three times higher than that of pre-Messinian Miocene, in agreement with the worldwide increase in marine sedimentation rates over the last 5 Ma. Unfortunately, we do not have a good age control on the exact timing of the Pliocene increase. It can be considered to occur during Early Pliocene, and would be, thus, due to regional persistent wetter and warmer 
climate after the MSC and/or regional tectonic changes. It can also occur later $(\sim 3.4 \mathrm{Ma})$ as an event that is strictly related to the beginning of world-wide climate deterioration. All these regional and global triggers can also contribute in a concomitant way to the increasing sediment yield over the last 5 Myr.

\section{Acknowlegments}

This research was funded by CNRS, IFREMER, UPMC and the GRI (Groupement Recherche et Industrie) Méditerranée with additional support from the French Actions-Marges program, the CNRS-INSU SYSTER program (EROGOL). This work also benefited from the Labex Mer initiative, a State Grant from the French Agence Nationale de la Recherche (ANR) in the Program « Investissements d'avenir » with the reference ANR10-LABX-19-01, Labex Mer. We thank also S. Berné for the use of MARION data set, D. Praeg for the digital version of Gennesseaux 's Plio-Quaternary map, J. Lofi for providing a digital version of her interpretation (used in Fig. 3 and 16) and F. Guillocheau for fruitful discussion and references about the Pliocene and Pleistocene paleogeographic patterns of the Rhine River. We are very grateful to P. Van der Beek, W. Cavazza, and an anonymous reviewer for their thoughtful comments on the manuscript. The final manuscript greatly benefited from their careful work in the review process. Stratigraphic interpretations were performed with Kingdom Suite software kindly made available to the University of Brest. The authors are grateful to Katalin Kovacs and Stefan Lalonde for post-editing the English style.

\section{Figures captions}

Fig. 1.

A) Location of the study area (delimited by a white rectangle on the right) on a topographic map of the Mediterranean region (on the left). B) Dataset and bathymetry of the Gulf of Lion (modified from Berné et al., 2002). Red triangles correspond to industrial wells, Blue triangles correspond to the two PROMESS European boreholes. Big green dots represent the ESP data, small green dots represent OBS data on Sardinia profiles. Thick black lines correspond to seismic lines shown in this paper. The thick purple line represents the end of the smooth abrasion surface RS (at $1.6 \mathrm{~s} \mathrm{twtt)} \mathrm{and} \mathrm{the} \mathrm{pink} \mathrm{thick} \mathrm{line} \mathrm{represents} \mathrm{the} \mathrm{limit} \mathrm{of} \mathrm{salt} \mathrm{(from} \mathrm{Bache} \mathrm{et} \mathrm{al.,}$ 2009).

Fig. 2 
Line-drawing of seismic line 96LRM18 located on the western shelf of the Gulf of Lions showing the major Pliocene, Pleistocene and Miocene markers that we identified. The Messinian Erosional Surface (pink) that results from erosion and incision of the Messinian fluvial network during the Messinian Salinity Crisis exhibits rough morphology and clearly individualizes Pliocene (blue) and Miocene intervals (yellow). Pliocene and Pleistocene strata shows a clear change in stacking pattern (shelf-slope breaks are indicated by black circles and shelf edge trajectory is plotted in black dotted line), from Late Pliocene prograding clinoforms to progradingaggrading Quaternary clinoforms after P11 (yellow). At the right top of the figure, a very high-resolution profile focuses on the erosional discontinuities for the last 0.45 Myr above Q5 (from Rabineau et al, 2006).

\section{Fig. 3}

Line-drawing of seismic lines 96LRM10 and 80LIGO22 showing the seismic units deposited on the margin during the Messinian Salinity Crisis and the two different interpretations for the base of the event. The base of the MSC corresponds to the Basal Surface (BS) and to the base of LU0 according to respectively Lofi et al., 2011 and Bache et al., 2009. PQ = PlioQuaternary, MES = Messinian Erosional Surface, BES = Basal Erosional Surface, BS = Basal Surface, UU = Upper Unit, MU = Mobile Unit, LU = Lower Unit, CU = Clastic Unit, RS = Ravinement surface (smooth surface). Location on Fig. 1.

\section{Fig. 4}

Line-drawing of seismic line 96LRM28 (NW-SE) on the shelf of the Gulf of Lion and correlation of the discontinuities on the distal part of the profile with Autan 1 borehole. The seismic stratigraphic architecture (with the complex of large prograding clinoforms with a typical topset-foreset-bottomset organisation) is similar to Fig. 2. Biostratigraphic data (from Cravatte et al., 1974) provide us information to estimate ages of the seismic markers: the appearance of NeoGlobo-Quadrina Atlantica for example allows us to date P11 at 2.6 Ma. Paleoenvironments were also analysed by Cravatte et al., 1974. We therefore suggest an interpretation with R/T cycles (Regressive/Transgressive cycle) on the right. Location on Fig. 1.

\section{Fig. 5.}

Correlation of the stratigraphic markers with well data showing the lithologies of each unit. Individual lithologic colums were drawn by Lofi, 2002 and Lofi et al., 2003. Above the base of the MSC, Autan 1 shows a thick unit $(500 \mathrm{~m})$ which is composed by two sub-units: silted clays and carbonated clays. The first sub-unit may 
correspond to the early Messinian detrital unit (LU0) according to Bache et al. (2012). This synthesis on lithologies for all wells allowed us to define the relative proportion of dominant facies (sand, shale and carbonate) for each unit in order to decompact them (cf Tab.4 \& Fig.13). Locations of wells on Fig.1.

\section{Fig. 6}

Line-drawing of the ECORS 1 profile in the Eastern part of the margin, showing the sedimentary architecture and the continuity of the seismic markers from shelf to deep basin. Location on Fig. 1.

\section{Fig. 7}

Line-drawing of the 96LRM10 and 80LIGO22 seismic profile on the Western part of the margin showing the sedimentary architecture and the stratigraphic continuity of the seismic markers from shelf to deep basin which is not always easy to draw. Location on Fig. 1. Pre-Messinian Miocene markers on the shelf are drawn but their age are not constrained. Faults (black lines) are also drawn.

\section{Fig. 8}

Correlation between the chronostratigraphic markers defined in this study and depositional environments as described in (Cravatte et al., 1974) deduced from well data. We interpreted them in a chronostratigraphic framework with Transgressive/Regressive sequences. Light gray, red and dark gray colors on $\mathrm{T} / \mathrm{R}$ trends respectively correspond to ante-MSC Miocene, MSC and Plio-Pleistocene intervals. Our sequence stratigraphic interpretation using the depositional environments is consistent between all wells only if we attribute the base of LU0 as the base of the MSC as suggested by Bache et al, 2009 (see the text for more explanation).

\section{Fig. 9}

Comparison between the sea-floor topographic map obtained in this study (using the seismic data) and bathymetric map based on compilation of IFREMER ${ }^{e s}$ multibeam echosounder data. The very good fit between the two maps shows the good resolution of the sea-floor map, and, by extension, of all isobath and isopach maps (all have been interpolated in the same way).

\section{Fig. 10}

A) Isopach maps (ms twtt) of individual Pliocene and Pleistocene units (see name and position of surfaces in Table 1 and seismic line Fig. 2). Present-day shelf-break (black) and locations of wells (black circles) are drawn 
on each map. B) Isopach maps (ms twtt) of our Messinian units. The smooth surface (blue line), the present-day shelf-break (black) and the messinian fluviatile network (pink) are drawn on each map. Normal faults (salt tectonic) from Dos Reis, 2001 are superimposed to thicknesses maps of UU \& MU. C) Isopach maps (ms twtt) the major stratigraphic units. D) Depth-converted thickness maps of the Pliocene and Pleistocene units. E) Depth-converted thickness maps of the major post-rift stratigraphic units.

\section{Fig. 11}

Compilation of porosity versus depth curves (black curves) for different lithologies: a) shale, b) sandstone, c) carbonates (from Allen \& Allen, 2005). Sonic (DT log) from GLP2 well (blue curve) is superimposed on a) and used to draw the best compaction law for decompacting shaly fraction of the stratigraphic units defined in this study (red curve on a). The superimposition of GLP2 sonic velocity curve fits the median curve of the compaction interval given by Allen \& Allen's (2005). So, the median curves (red curves on b) \& c) are assumed to be also representative of the porosity versus depth curve for sandstone and carbonates in the study area. These curves were used with the lithology and the mean burial depth defined for each unit from well data. We determined thus initial and final porosities for each unit and calculated volumes of uncompacted and zero porosity sediments.

\section{Fig. 12.}

Vertical dip sections B, C, D, E used for estimating the uncertainties on our sediment volumes. Sections are built by extracting depths of all seismic markers from isobaths maps along each transect. Based on an interpolation between these sections, we calculated the volume of sediments accumulated in the basin for each time interval and determined variances associated with each parameter using a statistical approach implemented in the numerical code developed by Jean Braun (see the text \& Guillocheau et al., 2012 for more explanation). Location of sections in the bottom right corner.

\section{Fig. 13}

Evolution through time of the post-rift sediment volumes in the Gulf of Lions margin with associated uncertainties. Sediment budgets are estimated for both uncompacted and solid sediments volumes. This study is focused on the last $6 \mathrm{Myr}$ but a total sediment volume is also calculated for pre-Messinian Miocene sediment. The Provence Basin has recorded a peak of detritus during the Messinian Salinity Crisis,,a three-fold increase of 
detritus between Miocene and Pliocene, a decrease at 2.6 Ma, and a nearly doubling around 0.9 Ma.

\section{Fig. 14}

Comparison of the evolution of compacted (zero porosity) detrital volumes assuming that (A) the base of the MSC corresponds to the base of LU1 (according to Lofi, 2002 and Lofi \& Berné, 2008) and (B) the base of the MSC corresponds to the base of LU0, a much deeper unit (according to Bache et al., 2009). Since detrital fraction in Lofi_LU (or Bache_LU1) is still unknown, we quantified detrital fluxes (undifferentiated between terrestrial and recycled material) by assuming successively $0 \%, 20 \%$ and $50 \%$ of terrigenous sediments within this unit. Recycled volume from Miocene shelf and Rhone valley (Bache et al., 2009) is superimposed with red bar in each interpretation. Note that vertical scale in B) is double than in A). These volume estimates are discussed in the text.

\section{Fig. 15}

Mapping of the area from which we calculated sediment budget history in the Gulf of Lions (thick black contour line). Thickness map (ms twtt) of offshore Pliocene and Pleistocene deposits is superimposed (blue-red scale corresponds to smaller to larger thicknesses. Main onshore sedimentary basins - Bresse graben, Rhine graben, Valence basin, and Western Molasse basin from Sissingh (1998) (in grey) - are superimposed on the present-day catchment area of the Gulf of Lions margin (in yellow). Black arrows show the sediment pathways from Rhone, Pyreneo-Languedocian, Ebro and Var rivers during Quaternary (from Droz et al., 2006) and from Sardinian canyons during the Messinian Salinity Crisis (fromGeletti et al., 2014). Main Quaternary offshore sedimentary systems (dotted black lines) are drawn from Droz et al, (2006). A dip NW-SE line-drawing (location of the seismic profile in red line on the map) displays the sedimentary architecture through the Provençal basin until Sardinian margin (scarp in shaded grey). Thick dotted line roughly separates Alpine influenced regions from Corsica and Sardinia. Most of the offshore sediments in the Gulf of Lions originate from the Rhone River which channels Alpine continental inputs into the Gulf of Lions, where the Petit-Rhône Fan is the largest turbidite system. See the text for more explanation.

\section{Fig. 16}

Synthesis of major stratigraphic conclusions about the Provence Basin with detrital flux evolution. These results are placed in a chronostratigraphic frame and linked with the local and/or global climate and tectonic events 
from literature. A peak of detritus during the MSC arises from major erosional processes and intense reworking both in onshore \& offshore domains. Decrease of sedimentation at 2.6 Ma is due to a change of the Rhine drainage pattern. Increase of sedimentation around 0.9 Ma is linked to the Mid-Pleistocene Climatic Revolution. The three-folds increase of detrital sedimentation during Pliocene compared to the pre-Messinian Miocene may be correlated with a wetter climate (Willett et al., 2006 and Willett, 2010) and/or a change in drainage network (Schlunegger and Mosar, 2011). Regional alpine exhumation on the last 5 Myr (Vernon et al., 2008) is contradicted by Bernet et al., 2001 and Glotzbach et al., 2011.

\section{Fig. 17}

Maps of the present-day (left) and Pliocene (right) catchment areas (red infill) of the Gulf of Lions showing the change in drainage pattern cut off the Aar network around 2.6 Ma.

\section{Tab. 1}

Synthesis of the post-rift stratigraphic markers considered in this study and their stratigraphic relationships.

\section{Tab. 2}

3D Velocity model used to convert time to depth. Velocities are estimated from borehole, sonic, ESP and OBS data.

\section{Tab. 3}

Sediment volumes and fluxes calculated in the Provence Basin for the last 23 Myr from isopach maps. Here, these quantifications are not corrected for remaining porosity. Timing of deposition of the Messinian unit is not still constrained. We calculated sediment fluxes for different hypothesis on time-intervals (from published papers) for information purposes. Since there is no consensus, the entire duration of the crisis (5.96 Ma-5.33 Ma) appears as the most relevant interval to estimate fluxes.

\section{Tab. 4}

Details of the quantification of uncompacted and solid sediment volumes after estimating the proportion of dominant facies from wells, the mean burial depth for each unit and the porosity loss for each facies from abacus curves (see the text for more explanation). 


\section{REFERENCES}

Afilhado, A., Moulin, M., Aslanian, D., Schnürle, P., Klingelhoefer, F., Nouzé, H., Rabineau, M., Leroux, E. \& Beslier, M.-O. (2015). Deep crustal structure across a young 1 passive margin from wide-angle and reflection seismic data (The SARDINIA Experiment) - II. Sardinia "es margin. BSGF, ILP Special volume, 126 (4-5), 331351.

Allen, P. \& Allen, J. (2005). Basin analysis, Principles and Applications, Blackwell Publishing Ltd, Second Edition, 549 pp.

Aloïsi, J.C. (1986). Sur un modèle de sédimentation deltaïque: contribution à la connaissance des marges passives. PhD thesis, University of Perpignan, $162 \mathrm{p}$.

Andeweg, B. \& Cloetingh, S., (1998). Flexure and „unflexure ef the North Alpine German-Austrian Molasse Basin: Constraints from forward tectonic modeling, in Mascle, A., Puigdefàbregas, C., Luterbacher, H.P., and Fernàndez, M. (Eds.), Cenozoic Foreland Basins of Western Europe: Geological Society of London Special Publication 134, p. 403-422.

Aslanian, D., Rabineau, M., Klingelhoefer, F., Moulin, M., Schnurle, P., Gailler, A., Bache, F., Leroux, E., Gorini, C., Droxler, A., Eguchi, N., Kuroda, J., Alain, K., Roure, F. \& Haq, B. (2012). Structure and evolution of the Gulf of Lions: The Sardinia seismic experiment and the GOLD (Gulf of Lions Drilling) project. Lead. Edge, $31,786-792$.

Bache, F. (2008). Evolution oligo-miocène des marges du micro-océan liguro-provençal, PhD thesis, Université de Bretagne Occidentale, 328p., http://www.ifremer.fr/docelec

Bache, F., Olivet, J.-L., Gorini, C., Rabineau, M., Baztan, J., Aslanian, D. \& Suc J.-P. (2009). Messinian erosional and salinity crises: View from the Provence Basin (Gulf of Lions, Western Mediterranean). Earth Planet. Sci. Lett., 286, 139-157. 
Bache, F., Olivet, J.-L., Gorini, C., Aslanian, D., Labails, C. \& Rabineau, M. (2010). Evolution of rifted continental margins: the case of the Gulf of Lions (Western Mediterranean Basin). Earth Planet. Sci. Lett., 292, $345-356$.

Bache, F., Popescu S.M., Rabineau, M., Gorini, C., Suc, J.P., Clauzon G., Olivet J-L., Rubino J-L., MelinteDobrinescu M.C., Estrada F., Londeix L., Armijo R., Meyer B., Jolivet L., Jouannic G., Leroux E., Aslanian D., Baztan J., Dos Reis A.T., Mocochain L., Dumurdzanov N., Zagorchev I., Lesic V., Tomic D., Cagatay M.N., Brun J-P., Sokoutis D., Csato I., Ucarkus G. \& Cakir Z. (2012). A two step process for the reflooding of the Mediterranean after the Messinian Salinity Crisis. Basin Research, 23, 1-29.

Bache, F., Gargani, J., Suc, J.-P., Gorini, C., Rabineau, M., Popescu, S.-M., Leroux, E., Do Couto, D., Jouannic, G., Rubino, J.-L., Olivet, J.-L., Clauzon, G., Dos Reis, A.T., Aslanian, D. (in press). Messinian evaporite deposition during sea-level rise in the Gulf of Lion (Western Mediterranean). Marine and Petroleum Geology (2015) http://dx.doi.org/10.1016/j.marpetgeo.2014.12.013

Baran, R., Friedrich, A. M. \& Schlunegger, F. (2014). The Late Miocene to Holocene erosion pattern of the Alpine foreland basin reflects Eurasian slab unloading beneath the Western Alps rather than global climate change. Lithosphere, 6 (2), 124-131.

Bassetti, M.A., Berné, S., Jouet, G., Taviani, M., Dennielou, B. Flores, J., Gaillot, A., Gelfort, R., Lafuerza, S. \& Sultan, N. (2008). The 100-ka and rapid sea level changes recorded by prograding shelf sand bodies in the Gulf of Lions (western Mediterranean Sea). Geochem. Geophys. Geosyst., 9, Q11R05, doi:10.1029/2007GC001854.

Baztan, J., Berné, S., Olivet, J.-L., Rabineau, M., Aslanian, D., Gaudin, M., Réhault, J.-P. \& Canals, M. (2005). Axial incision : The key to understand submarine canyon evolution (in the Western Gulf of Lion). Marine and Petroleum Geology, 22 (6-7), 805-826. 
Benson, R.H., Rakic-El Bied, K. \& Bonaduce, G. (1991). An important current reversal (influx) in the Rifian Corridor (Morocco) at the Tortonian-Messinian boundary: the end of Tethys Ocean. Paleoceanography, 6 (1), 165-192.

Berger, J.-P., Reichenbacher, B., Becker, D., Grimm, M., Grimm, K., Picot, L., Storni, A., Pirkenseer, C., Derer, C. \& Schaefer, A. (2005). Paleogeography of the Upper Rhine Graben (URG) and the Swiss Molasse Basin (SMB) from Eocene to Pliocene. Int. J. Earth Sci (Geol Rundsch), 94, 697-710.

Bernet, M., Zattin, M., Garver, J. I., Brandon, M. T. \& Vance, J. A. (2001). Steady-state exhumation of the European Alps. Geology, 29(1), 35-38.

Bessis, F. (1986). Some remarks on the study of subsidence of sedimentary basins: application to the Gulf of Lions margin (Western Mediterranean). Mar. Pet. Geol., 3, 37-63.

Boyer, G. (1885). Sur la provenance et la dispersion de galets silicatés et quartzeux dans leintérieur et le pourtour des Monts Jura. Imprimerie Dodivers et Cie, 1885, 35p.

Bruch, A. A., Utescher, T., Mosbrugger, V., Gabrielyan, I., \& Ivanov, D. A. (2006). Late Miocene climate in the circum-Alpine realm-a quantitative analysis of terrestrial palaeofloras. Palaeogeography, Palaeoclimatology, Palaeoecology, 238(1), 270-280.

Brun, L., Castet, A., Grosdidier, P., Moreau, P., Prestat, B., Seyve, C., Cussey, R., Fajerwerg, R., Brevart,O., Chennaux, G., Severac, J., Barlier, J., Palacios, C.\& Poumot, C. (1984). Sondage Golfe du Lion profond $n^{\circ} 2$ GLP2, France, études de laboratoire, SNEAP, Direction Exploration, Division recherches et applications en géologie, Boussens.

Burbank, D.W., Leland, J., Fielding, E., Anderson, R.S., Brozovic, N., Reid, M.R \& Duncan, C. (1996). Bedrock incision, rock uplift and threshold hillslopes in the northwestern Himalayas. Nature, 379, 505-510. 
Burrus, J. (1989). Review of geodynamic models for extensional basins; the paradox of stretching in the Gulf of Lions (NorthWest Mediterranean). Bull Soc. Géol. France, 8, 377-393.

Calais, E., Nocquet, J.-M., Jouanne, F. \& Tardy, M. (2002). Current strain regime in the Western Alps from continuous GPS measurements, 1996-2001. Geology, 30(7), 651-654.

Cande, S. C., Raymond, C. A., Stock, J. \& Haxby, W. F. (1995). Geophysics of the Pittman Fracture Zone and Pacific-Antarctic plate motions during the Cenozoic. Science, 270, 947-953.

Carnevale, G., Landini, W. \& Sarti, G. (2006). Mare versus Lago-mare : marine fishes and the Mediterranean environment at the end of the Messinian Salinity Crisis. Journal of the Geological Society, London, 163, 75-80.

Cavazza, W. \& DeCelles, P. G. (1998). Upper Messinian siliciclastic rocks in southeastern Calabria (southern Italy): palaeotectonic and eustatic implications for the evolution of the central Mediterranean region: Tectonophysics, 298, 223-241.

Cederbom, C., Sinclair, H., Schlunegger, F. \& Rahn, M. (2004). Climate-induced rebound and exhumation of the European Alps. Geology, 32(8), 709-712.

Cerling, T. E., Harris, J. M., MacFadden, B. J., Leakey, M. G., Quade, J., Eisenmann, V., \& Ehleringer, J. R. (1997). Global vegetation change through the Miocene/Pliocene boundary. Nature, 389(6647), 153-158.

Chaline, J. (1984). La séquence des rongeurs de Bresse en tant que référence biostratigraphique et paléoclimatique. Géologie de la France, 3, 331-336.

Champagnac, J.-D., Molnar, P., Anderson, R.S., Sue, C. \& Delacou, B. (2007). Quaternary induced isostatic rebound in the Western Alps. Geology, 35(3), 195-198.

Champagnac, J.-D., Van der Beek, P. Diraison, G. \& Dauphin, S. (2008). Flexural Isostatic response of the Alps to increased Quaternary Erosion recorded by foreland basin remnants, SE France. Terra Nova, 20, 213-220. 
Champagnac, J.D., Schlunegger, F., Norton, K., von Blanckenburg, F., Abbuhl, L.M. \& Schwab, M. (2009). Erosion-driven uplift of the modern Central Alps. Tectonophysics, 474(1-2), 236-249.

CIESM (2008). The Messinian Salinity Crisis from mega-deposits to microbiology. A consensus report. In: CIESM workshop Monograph (Ed. by F. Briand), 33, 1-26.

Clauzon, G. (1982). Le canyon messinien du Rhône : une preuve décisive du" desiccated deep-basin model" (Hsü, Cita and Ryan, 1973). Bulletin de la Société géologique de France, (3), 597-610.

Clauzon, G., Le Strat, P., Duvail, C., Do Couto, D., Suc, J.-P., Molliex, S., Bache, F., Besson, D., Lindsay, E.H., Opdyke, N.D., Rubino, J.-L., Popescu, S. M., Haq, B.U. \& Gorini, C. (2015). The Roussillon Basin (S. France): a case-study to distinguish local from regional events between 6 and 3 Ma. Marine and Petroleum geology, doi:10.1016/j.marpetgeo.2015.03.012.

Cloetingh, S., Gradstein, F.M., Kooi, H., Grant, A.C. \& Kaminski, M. (1990). Plate reorganization: a cause of rapid late Neogene subsidence and sedimentation around the North Atlantic? Journal of the Geological Society, London, 147, 495-506.

Cox, A. \& Engebretson, D. (1985). Change in motion of Pacific plate at 5 Myr BP. Nature, 313, 472-474.

Cravatte, J., Dufaure, P., Prim, M. \& Rouaix, S. (1974). Les sondages du golfe du lion : Stratigraphie, sédimentologie, Compagnie Française des Pétroles, Paris.

Cravatte, J. \& Suc, J.-P. (1981). Climatic evolution of North-Western Mediterranean area during Pliocene and Early Pleistocene by pollen-analysis and forams of drill Autan 1. Chronostratigraphic correlations. Pollen et Spores, 23, 2, 247-258.

Davies, J. H., \& von Blanckenburg, F. (1995). Slab breakoff: a model of lithosphere detachment and its test in the magmatism and deformation of collisional orogens. Earth and Planetary Science Letters, 129(1), 85-102. 
De Lamothe (1903). Sur le passage du Rhin par la vallée du Doubs et la Bresse pendant le Pliocène. ComptesRendus de l'Académie des Sciences, 136, 389-391.

De Voogd, B., Nicolich, R., Olivet, J.L., Fanucci, F., Burrus, J., Mauffret, A., Pascal, G., Argnani, A., Auzende, J.M., Bernabini, M., Bois, C., Carmignani, L., Fabbri, A., Finetti, I., Galdeano, A., Gorini, C.Y., Labaume, P., Lajat, D., Patriat, P., Pinet, B., Ravat, J., Ricci Lucchi, F. \& Vernassa, S. (1991). First deep seismic reflection transect from the Gulf of Lions to Sardinia (ECORS-CROP profiles in Western Mediterranean). In: Continental Lithosphere: Deep seismic reflections (Ed. by R. Meissner), American Geophysical Union, 265-274.

Dos Reis, A. (2001). La tectonique salifère et son influence sur l'architecture sédimentaire quaternaire de la marge du golfe du lion - méditerranée occidentale. PhD thesis, Université Pierre et Marie Curie, Paris 6, 372p.

Dos Reis, A., Gorini, C. \& Mauffret, A. (2005). Implications of salt-sediment interactions of the architecture of the Gulf of Lions deep water sedimentary systems - Western Mediterranean sea. Mar. Petrol. Geol., 22, 713746.

Droz, L., Dos Reis, A. T., Rabineau, M., Berne, S. \& Bellaiche, G. (2006). Quaternary turbidite systems on the northern margins of the Balearic Basin (Western Mediterranean): a synthesis. Geo-Marine Letters, 26(6), 347359.

Estrada F., Ercilla, G., Gorini, C., Alonso, B., Vazquez, J.T., Garcia-Castellanos, D., Juan, C., Maldonado, A., Ammar, A. \& Elabbassi, M. (2011). Impact of pulsed Atlantic water inflow into the Alboran Basin at the time of the Zanclean flooding. Geo-Marine Letters, Volume 31, Issue 5-6, 1-16.

Farjanel, G. (1985). La flore et le climat du Néogène et du Pléistocène de Bresse (France) d'aaprès l'analyse pollinique. Implications chronostratigraphiques. Doc. BRGM, Orléans, 97, 202p.

Fauquette, S., Suc, J. P., Guiot, J., Diniz, F., Feddi, N., Zheng, Z., Bessais, E. \& Drivaliari, A. (1999). Climate and biomes in the West Mediterranean area during the Pliocene. Palaeogeography, Palaeoclimatology, Palaeoecology, 152(1), 15-36. 
Fauquette, S., Suc, J.-P., Bertini, A., Popescu, S. M., Warny, S., Taoufiq, N. B., Perez-Villa, M.J., Chikhi, H., Feddi, N., Subally, D., Clauzon, G. \& Ferrier, J. (2006). How much did climate force the Messinian salinity crisis? Quantified climatic conditions from pollen records in the Mediterranean region. Palaeogeography, Palaeoclimatology, Palaeoecology, 238(1), 281-301.

Ferrandini, J., Gattacceca, M, Ferrandini, M., Deino, A. \& Janin, M. (2003). Chronostratigraphy and paleomagnetism of oligo-miocene deposits of Corsica (France): geodynamic implications for the liguroProvence Basin spreading. Bull. Soc. Geol. France, 174(4), 357-371.

Fortelius, M., Eronen, J., Jernvall, J., Liu, L., Pushkina, D., Rinne, J., Tesakov, A., Vislobokova, I., Zhang, Z. \& Zhou, L. (2002). Fossil mammals resolve regional patterns of Eurasian climate change over 20 million years. Evolutionary Ecology Research, 4(7), 1005-1016.

Fox, M., Herman, F., Kissling, E., \& Willett, S. D. (2015b). Rapid exhumation in the Western Alps driven by slab detachment and glacial erosion. Geology, 43(5), 379-382.

Garcia-Castellanos, D., Estrada, F., Jiménez-Munt, I., Gorini, C., Fernàndez, M., Verges, J. \& Vicente, R.D. (2009). Catastrophic flood of the mediterranean after the messinian salinity crisis, Nature, 462, 778-781.

Gattacceca, J., Deino, A., Rizzo, R., Jones, D., Henry, B., Beaudoin, B. \& Vadeboin, F. (2007). Miocene rotation of Sardinia: New paleomagnetic and geochronological constraints and geodynamic implications. Earth Planet. Sci. Lett., 258, 359-377.

Genser, J., Cloething, S.A.P.L. \& Neubauer, F. (2007). Late orogenic rebound and oblique Alpine convergence: New constraints from subsidence analysis of the Austrian Molasse basin. Global and Planetary Change, 58, 214-223, doi:10.1016/j.gloplacha.2007.03.010.

Gibbard, P., Head M.J., Walker, M. J. C \& the International Subcommission on Quaternary Stratigraphy (Alloway, B., Beu, A.G., Coltorti, M., Hall, V. M., Jiaqi, L., Knudsen, K.L., van Kolfschoten, T., Litt, T., Marks, L., McManus, J., Partridge, T.C., Piotrowski, J.A., Pillans, B., Rousseau, D.-D., Suc, J.-P., Tesakov, A.S., 
Turner \& Zazo, C. (2010). Formal ratification of the Quaternary System/Period and the Pleistocene Series/Epoch with a base at 2.58 Ma. Journal of Quaternary Sciences, 25, 2, 96-102.

Glotzbach, C., Van der Beek, P.A. \& Spiegel, C. (2011a). Episodic Exhumation and relief growth in the Mont Blanc massif, Western Alps from numerical modelling of thermochronology data. Earth Planet. Sci. Lett., 304, 417-430

Glotzbach, C., Beek, P., Carcaillet, J., \& Delunel, R. (2013). Deciphering the driving forces of erosion rates on millennial to million-year timescales in glacially impacted landscapes: An example from the Western Alps. Journal of Geophysical Research: Earth Surface, 118(3), 1491-1515.

Gorini, C. (1993), Géodynamique d'une marge passive : le Golfe du Lion (Méditerranée Occidentale), PhD thesis, Université Paul Sabatier, Toulouse, 256p.

Gorini, C., Lofi, J., Duvail, C., Dos Reis, T., Guennoc, P., Le Strat, P. \& Mauffret, A. (2005). The Late Messinian salinity crisis and Late Miocene tectonism: interaction and consequences on the physiography and post-rift evolution of the Gulf of Lions margin. Mar. Pet. Geol., 22, 695-712.

Gorini, C., Montadert, L. \& Rabineau, M. (in press). Dual Messinian lowstand megasequences in the deep basin of the Eastern and western Mediterranean: a combined conceptual model. Marine \& Petroleum Geology, doi:10.1016/j.marpetgeo.2015.01.009.

Guennoc, P., Gorini, C. \& Mauffret, A. (2000). Histoire géologique du Golfe du Lion et cartographie du rift oligo-aquitanien et de la surface messinienne. Géologie de la France, 3, 67-97.

Guillocheau, F., Rouby, D., Robin, C., Helm, C, Rolland, N., Le Carlier de Veslud, C. \& Braun, J. (2012). Quantification and causes of the terrigenous sediment budget at the scale of a continental margin: a new method applied to the Namibia-South Africa margin. Basin Research, 24 (1), 3-30. 
Haeuselmann, P., Granger, D.E., Jeannin, P.-Y. \& Lauritzen, S.-E. (2007). Abrupt glacial valley incision at 0.8 Ma dated from cave deposits in Switzerland. Geology, 35, 143-146.

Haq, B. \& Schutter, S. (2008). A chronology of Paleozoic sea-level changes. Science, 3, 64-68.

Hay, W., Sloan, J. \& Wold, C. (1988). Mass/age distribution and composition of sediments on the ocean floor and the global rate of sediment subduction. J. Geophys. Res., 93, 14 933-14 940.

Hay, W. W., Wold, C. N. \& Herzog, J. M. (1992). Preliminary mass-balanced 3-D reconstructions of the Alps and surrounding areas during the Miocene. In Computer Graphics in Geology (pp. 99-110). Springer Berlin Heidelberg.

Hay, W., Soeding, E, DeConto, R. \& Wold, C. (2002). The late Cenozoic uplift - climate change paradox. Int. J. Earth Sci., 91(5), 746-774.

Head, M \& Gibbard, P., (2005). Early-middle Pleistocene transitions: the land-ocean evidence. Geological Society, London, Spec. Pub., 247.

Herman, F., Seward, D., Valla, P.G., Carter, A., Kohn, B., Willett, S.D. \& Ehlers, T.A. (2013). Worldwide acceleration of mountain erosion under a cooling climate. Nature, 504, 423-426.

Hsü, K., Cita, M. \& Ryan, W. (1973). The origine of the Mediterranean evaporites. In: Initial Report of the Deep Sea Drilling Project 13 (Ed. by W.B.F. Ryan, K.J. Hsü and al.), U.S. Government Printing Office, Washington, $1203-1231$.

Hunziker, J.C., Desmons, J. \& Hufford, A.J., (1992). Thirty-two years of geochronological work in the Central and Western Alps: A review on seven maps. Mém. Géol. (Lausanne), 13, 59p.

Imbrie, J., Hays, J. D., Martinson, D. G., McIntyre, A., Mix, A. C., Morley, J. J., Pisias, N. G., Prell W. L. \& Shackleton, N. J. (1984). The orbital theory of pleistocene climate : support from a revised chronology of the 
marine $\delta 180$ record - In: Milankovitch and climate (Ed. by A. Berger, J. Imbrie, J. Hays, G. Kukla, B. Saltzman) 126, 269-305.

Joannin, S., Bassinot, F., Combourieu Nebout, N., Peyron, O. \& Beaudouin, C. (2011). Vegetation response to obliquity and precession forcing during the Mid-Pleistocene Transition in Western Mediterranean region (ODP Site 976). Quaternary Science Reviews, 30, 280-297.

Keigwin, L. D (1986). Pliocene stable isotope record of Deep Sea Drilling Project Site 606: Sequential event of ${ }^{18} \mathrm{O}$ enrichment beginning at 3.1 Ma. In W. F. Ruddiman, R. B. Kidd, E. Thomas et al. (Eds.), Init. Reports. DSDP. 94, U. S. Govt. Printing Office, Washington, pp. 911-920.

Kissling, E. (1993). Deep structure of the Alps - what do we really know? Physics of the Earth and Planetary Interiors, 79, 87-112, doi:10.1016/0031-9201(93)90144-X.

Krijgsman, W., Hilgen, F., Raffi, I., Sierro, F. \& Wilson, D. (1999a). Chronology, causes and progression of the messinian salinity crisis. Nature, 400(12), 652-655.

Krijgsman, W, Langereis, C.G., Zachariasse, W.J., Boccaletti, M., Moratti, G., Gelati, R., Iaccarino, S., Papani, G. \& Villa, G. (1999b). Late Neogene evolution of the Taza-Guercif Basin (Rifian Corridor; Morocco) and implications for the Messinian salinity crisis. Mar. Geol., 153, 147-160.

Kuhlemann, J. (2000). Post-collisional sediment budget of circum-alpine basins (central europe). Mem. Sci. Geol., Padova 52, 1-91.

Kuhlemann, J., Frisch, W., Dunkl, I. \& Székely, B. (2001). Quantifying tectonic versus erosive denudation by the sediment budget: the Miocene core complexes of the Alps. Tectonophysics, 330, 1-23.

Kuhlemann, J. \& Kempf, O. (2002). Post-Eocene evolution of the North alpine foreland basin and its reponse to alpine tectonics. Sedimentary Geology, 152, 45-78.

Kuhlemann, J., Frisch, W., Székely, B., Dunkl, I. \& Kazmer, M. (2002). Post-collisional sediment budget history of the Alps: tectonic versus climatic control. Int. J. Earth Sci. (Geol Rundsch), 91, 818-837. 
Kuhlemann, J. (2007). Paleogeographic and paleotopographic evolution of the Swiss and Eastern Alps since the Oligocene. Global and Planetary Change, 58, 224-236.

Lear, C., Elderfield, H. \& Wilson P. (2000). Cenozoic deep-sea temperatures from $\mathrm{mg} / \mathrm{ca}$ in benthic foraminiferal calcite. Science, 287, 269-272.

Le Douaran, S., Burrus, J. \& Avedik, F. (1984). Deep structure of the North-West Mediterranean basin: results of two-ship seismic survey. Mar. Geol., 55, 325-345.

Leroux, E. (2012). Quantifications des flux sédimentaires et de la subsidence dans le bassin Provençal, Mediterranée Occidentale. PhD thesis, Université de Bretagne Occidentale, Brest, 455p.

Leroux, E., Rabineau, M., Aslanian, D., Granjeon, D., Gorini, C. \& Droz, L. (2014). Stratigraphic simulation on the shelf of the gulf of lion: testing subsidence rates and sea-level curves during pliocene and quaternary. Terra Nova, 26(3), 230-238.

Lippitsch, R., Kissling, E. \& Ansorge, J. (2003). Upper mantle structure beneath the Alpine orogeny from highresolution teleseismic tomography. Journal of Geophysical Research, 108(B8), 2376, doi:10.1029/2002JB002016.

Lisiecki, L. \& Raymo, M., (2005). A pliocene-pleistocene stack of 57 globally distributed benthic $\delta^{18} \mathrm{O}$ records. Paleoceanography, 20, PA1003, doi:10-1029/2004PA001071.

Lofi, J., Rabineau, M., Gorini, C., Berne, S., Clauzon, G., De Clarens, P., Tadeu Dos Reis, A., Mountain, G.S., Ryan, W.B.F., Steckler, M.S. \& Fouchet, C. (2003). Plio-Quaternary prograding clinoform wedges of the western Gulf of Lion continental margin (NW Mediterranean) after the Messinian Salinity Crisis. Mar. Geol., 198, 289-317. 
Lofi, J., Gorini, C., Berné, S., Clauzon, G., Reis, A. D., Ryan, W. \& Steckler, M. (2005). Erosional processes and paleo- environmental changes in the western Gulf of Lions (SW France) during the messinian salinity crisis. Mar. Geol., 217, 1-30.

Lofi, J. \& Berné, S. (2008). Evidence for pre-messinian submarine canyons on the Gulf of Lions slope (Western Mediterranean). Mar. Petrol. Geology, 25(8), 804-817.

Lofi, J., Sage, F., Deverchère, J., Loncke, L., Maillard, A., Gaullier, V., Thinon, I., Gillet, H., Guennoc, P. \& Gorini, C. (2011). Refining our knowledge of the Messinian Salinity crisis records in the offshore domaine through multi-site seismic analysis. Bull. Soc. Géol. Fr., 182, 163-180.

Loget, N., Davy, P. \& Van Den Driessche (2006). Mesoscale fluvial erosion parameters deduced from modeling the Mediterranean sea-level drop during the Messinian (late Miocene). J. Geophys. Res., 111, F03005, doi:10.1029/2005JF000387

Loget, N. \& Van Den Driessche, J. (2009). Wave train model for knickpoint migration. Geomorphology, 106, 376-382.

Lourens, L., Hilgen, F., Shackleton, N., Laskar, J. \& Wilson, D. (2004). The Neogene period. In: A geologic Time Scale 2004 (Ed. by F.M. Gradstein, J.G. Ogg, A.G. Smith), Cambridge University Press, Cambridge, UK, 409-440.

Lyon-Caen, H. \& Molnar, P. (1989). Constraints on the deep structure and dynamic processes beneath the Alps and adjacent regions from an analysis of gravity anomalies. Geophysical Journal International, 99, 19-32, doi:10.1111/j.1365-246X.1989.tb02013.x.

Mauffret, A., Pascal, G., Maillard, A. \& Gorini, C. (1995). Tectonics and deep structure of the North-Western Mediterranean basin. Mar. Petrol. Geol., 12(6), 645-646. 
Mauffret, A., de Grossouvre, B. D., Dos Reis, A. T., Gorini, C., \& Nercessian, A. (2001). Structural geometry in the Eastern Pyrenees and Western Gulf of Lion (Western Mediterranean). Journal of Structural Geology, 23(11), $1701-1726$.

Mitchum, R.M. \& Vail, P. (1977). Seismic stratigraphic interpretation procedure. In: Seismic stratigraphy Applications to hydrocarbon exploration (Ed. by C.E. Payton), AAPG memoir, 135-143.

Molnar, P \& England, P. (1990). Late Cenozoic uplift of mountain ranges and global climate change: chicken or egg? Nature, 346, 29-34

Molnar, P. (2004). Late Cenozoic increase in accumulation rates of terrestrial sediment: How might climate change have affected erosion rates? Annual Review of Earth And Planetary Sciences, 32, 67-89.

Moulin, M., Klingelhoefer, F., Afilhado, A., Aslanian, D., Schnurle, P., Nouzé, H., Rabineau, M., Beslier, M.O \& Feld, A. (2015). Deep crustal structure across an young passive margin from wide- angle and reflection seismic date (The SARDINIA Experiment) - I- Gulf of Lion's Margin. BSGF, ILP special Volume, 186 (4-5), 309-330.

Muttoni, G., Carcano, C., Garzanti, E., Ghielmi, M., Piccin, A., Pini, R., Rogledi, S. \& Sciunnach, D. (2003). Onset of Pleistocene glaciations in the Alps. Geology, 31, 989-992.

Pascal G., Mauffret, A. \& Patriat, P. (1993). The ocean-continent boundary in the Gulf of Lions from analysis of expanding spread profiles and gravity modelling. Geophys. J. Int., 113, 701-726.

Petit, C. (1993). Un bassin d'avant-pays de type pelliculaire, la Bresse au Plio-Pléistocène. Thèse de l'euniversité de Bourgogne, 348p.

Petit, C., Campy, M., Chaline, J. \& Bonvalot, J. (1996). Major palaeohydrographic changes in Alpine foreland during the Pliocen-Pleistocene. Boreas, 25, 131-143.

Pollitz, F.F. (1986). Pliocene change in Pacific-plate motion. Nature, 320, 738-741. 
Pont, D., Simonnet, J. P. \& Walter, A. V. (2002). Medium-term changes in suspended sediment delivery to the ocean: consequences of catchment heterogeneity and river management (Rhône River, France). Estuarine, Coastal and Shelf Science, 54(1), 1-18.

Popescu, S.-M., Biltekin, D., Winter, H., Suc, J.-P., Melinte-Dobrinescu, M.C., Klotz, S., Combourieu-Nebout, N., Rabineau, M., Clauzon, G. \& Deaconu, F. (2010). Pliocene and Lower Pleistocene vegetation and climate changes at the European scale: Long pollen records and climatostratigraphy. Quaternary International, 219, $152-$ 167.

Poulos, S. E. \& Collins, M. B. (2002). Fluviatile sediment fluxes to the Mediterranean Sea: a quantitative approach and the influence of dams. Geological Society, London, Special Publications, 191(1), 227-245.

Prell, W.L. (1984). Covariance patterns of Foraminiferal d180 : an evaluation of Pliocene Ice Volume Changes Near 3.2 Millions Years Ago. Science, 226(4675), 692-694.

Puissegur, J.-J. (1984). Les faunes malacologiques de la Bresse. Significations écologiques, climatiques et chronologiques. Géologie de la France, 3, 281-302.

Rabineau, M. (2001). Un modèle géométrique et stratigraphique des séquences de dépôs quaternaires de la plateforme du golfe du lion : enregistrement des cycles glacioeustatiques de 100 000ans, $\mathrm{PhD}$ thesis, Université de Rennes 1/IFREMER, 392p., http://www.ifremer.fr/docelec

Rabineau, M., Berne, S., Aslanian, D., Olivet J.L., Joseph, P., Guillocheau, F., Bourrillet, J.-F., Le Drezen, E. \& Granjeon, D. (2005). Sedimentary sequences in the Gulf of Lion: A record of 100,000 years climatic cycles. Marine and Petroleum Geology 22(6-7), 775-804.

Rabineau, M., Berne , S., Olivet J.L., Aslanian, D., Guillocheau, F. \& Joseph, P. (2006). Paleo sea levels reconsidered from direct observation of paleoshoreline position during Glacial Maxima (for the last 500,00 yr). Earth Planet. Sci. Lett. 252, 119-137. 
Rabineau, M., Leroux, E., Aslanian, D., Bache, F., Gorini, C., Moulin, M., Molliex, S., Droz, L., Reis, A.D., Rubino, J.-L., Guillocheau, F. \& Olivet, J.-L. (2014). Quantifying subsidence and isostatic readjustment using sedimentary paleomarkers, example from the Gulf of Lions. Earth Planet. Sci. Lett. 388, 1-14.

Réhault, J.P., Boillot, G. \& Mauffret, A. (1984). The western Mediterranean Basin geological evolution. Mar. Geol. 55, 445-475.

Ruddiman, W., McIntyre, A. \& Raymo, M. (1986). Paleoenvironmental results from North Atlantic sites 607 and 609. In: Initial reports Deep Sea Drilling project, part 2, vol. 94 (Ed. by W.F. Ruddiman, R.B. Kidd, E. Thomas et al.). US Govt Printing Office, Washington, DC, 855-878.

Ryan, W.B.F. \& Cita, M.B. (1978). The nature and distribution of Messinian erosional surfaces -indicators of a several-kilometer deep Mediterranean in the Miocene. Marine Geology 27, 193-230.

Ryan, W.B.F. (2011). Geodynamic responses to a two-step model of the messinian salinity crisis. Bull. Soc. Géol. Fr. 182, 73-78.

Sadler, P.M. (1981). Sediment accumulation rates and the completeness of stratigraphic sections. The Journal of Geology 89, 569-584.

Sadler, P.M. \& Strauss, D.J. (1990). Estimation of completeness of stratigraphical sections using empirical data and theoretical models. Journal of the Geological Society 147, 471-485.

Schlunegger, F. \& Mosar, J. (2011). The Last erosional stage of the Molasse Basin and the Alps. Int. J. Earth Sci. $100,1147-1162$.

Schmid, S.M., Pfiffner, O.A., Froitzheim, N., Schönborn, G. \& Kissling, E. (1996). Geophysical-geological transect and tectonic evolution of the Swiss-Italian Alps. Tectonics, 15, 1036-1064. 
Schumer, R. \& Jerolmack, D.J. (2009). Real and apparent changes in sediment deposition rates through time. J. Geophys. Res. 114 (3), F00A06, DOI: 10.1029/2009JF001266.

Séranne, M., Benedicto, A., Labaum, P., Truffert, C., \& Pascal, G. (1995). Structural style and evolution of the Gulf of Lion Oligo-Miocene rifting: Role of the Pyrenean orogeny. Marine and Petroleum Geology, 12(8), 809820.

Séranne, M. (1999). The Gulf of Lion continental margin (NW MEditerranean) revisited by IBS: an overview. In: The Mediterranean Basins: Tertiary Extension within the Alpine Orgogen (Ed. by B. Durand., L. Jolivet, F. Horvath, M. Seranne), Special publication, Geological Society of London.

Serpelloni, E., Faccenna, C., Spada, G., Dong, D. \& Williams, S.D.P. (2013). Vertical GPS ground motion rates in the Euro-Mediterranean region: New evidence of velocity gradients at different spatial scales along the NubiaEurasia plate boundary. Journal of Geophysical Research, 118 (11), 6003-6024.

Shackleton, N. J. (1997). The deep-sea sediment record and the Pliocene-Pleistocene boundary. Quaternary International, 40, 33-35.

Sierro F.J., Andersen N., Bassetti M.A., Berné S., Canals M., Curtis J.H., Dennielou B., Flores J.A., Frigola J., Gonzalez-Mora B., Grimalt J.O., Hodell D.A., Jouet G., Pérez-Folgado M. \& Schneider R. (2009). Phase relationship between sea level and abrupt climate change. Quaternary Science Reviews, 28, 2867-2881.

Speranza, F., Villa, I., Sagnotti, L., Florindo, F., Cosentino, D., Cipollari, P. \& Mattei, M. (2002). Age of the Corsica-Sardinia rotation and Liguro-Provence Basin spreading: new paleomagnetic and ar/ar evidence, Tectonophysics, 347, 231-251.

Suc, J.-P. (1984). Origin and evolution of the Mediterranean vegetation and climate in Europe. Nature, 307 , 5950, 429-432.

Suc, J.-P. \& Drivaliari, A. (1991). Transport of bisaccate coniferous fossil pollen grains to coastal sediments. An exemple from the earliest Pliocene Orb ria (Languedoc, southern France). Rev. Palaeobot. Palynol., 70, $247-253$. 
Suc, J.-P., Clauzon, G., Bessedik, M., Leroy, S., Zheng, Z., Drivaliari, A., Roiron, P., Ambert, P., Martinell, J., Domenech, R., Matias, I., Julia, R. \& Anglada, R. (1992). Neogene and Lower Pleistocene in Southern France and Northeastern Spain. Mediterranean environments and climate. Cahiers de Micropaléontologie, 7 (1/2), 165 186.

Suc, J.-P., Fauquette, S., Bessedik, M., Bertini, A., Zheng, Z., Clauzon, G., Suballyova, D., Diniz, F., Quézel, P., Feddi, N., Clet, M., Bessais, E., Bachiri Taoufiq, N., Méon, H. \& Combourieu-Nebout, N. (1999). Neogene vegetation changes in West European and West circum-Mediterranean areas. In "Hominid Evolution and Climate in Europe", 1 "Climatic and Environmental Change in the Neogene of Europe" (Ed. by J. Agusti, L. Rook, P. Andrews), Cambridge University Press, 370-385.

Sue, C., Delacou, B., Champagnac, J.-D., Allanic, C., Tricart, P. \& Burkhard, M. (2007). Extensional neotectonics around the bend of the Western/Central Alps: An overview. International Journal of Earth Sciences, 96, 1101-1129, doi:10.1007/s00531-007-0181-3.

Vail, P., Mitchum, R., Todd, R., Widmier, J., Thompson, S., Sangree, J., Bubb, J. \& Hatlelid, W. (1977). Seismic stratigraphy and global changes of sea-level, Seismic Stratigraphy - Applications to hydrocarbon exploration, vol. Memoir 26, American Association of Petroleum Geologists, Tulsa.

Valla, P., Shuster, D. L. \& Van der Beek, P. (2011). Significant increase in relief of the european alps during mid-pleistocene glaciations. Nature, 4, 688-692.

Van Couvering, J.A.; Castradori, D.; Cita, M. B. \& Hilgen, F.J. (2000). The base of the Zanclean Stage and of the Pliocene Series. Episodes, 23(3), 179-187.

Vernant, P., Hivert, F., Chery, J., Steer, P., Cattin, R., \& Rigo, A. (2013). Erosion-induced isostatic rebound triggers extension in low convergent mountain ranges. Geology, 41(4), 467-470. 
Vernon, A.J., Van der Beek, P., Sinclair, H.D., Rahn, M.K., 2008. Increase in late Neogene denudation of the European Alps confirmed by analyses of a fission-track thermochronology datatbase. Earth and Planetary Science Letter, 270, 316-329.

Wagner, R., Fabel, D., Fiebig, M., Häuselmann, P., Sahy, D., Xu, S. \& Stüwe, K. (2010). Young uplift in the non-glaciated parts of the eastern Alps. Earth and Planetary Science Letters, 295, 159-169, doi:10.1016/j.epsl.2010.03.034

Wessel, P. \&vSmith, W. (1995). A new version of the generic mapping tools (gmt), EOS Trans. Am. Geophys. Un., 76(329).

Wijermars, R. (1988). Neogene tectonics in the Western Mediterranean may have caused the Messinian Salinity Crisis and an associated glacial event. Tectonophysics, 148, 211-219.

Willenbring, J. \& Blanckenburg, F. V. (2010). Long-term stability of global erosion rates and weathering during Late-Cenozoic cooling. Nature, 465, 211-214.

Willett, S.D., Schlunegger, F. \& Picotti, V. (2006). Messinian climate change and erosional destruction of the central European Alps. Geology, 34(8), 613-616.

Willett, S.D. (2010). Late Neogene erosion of the Alps: a Climate Driver? Annual Review of Earth and Planetary Sciences, 38, 411-437.

Wilson, D. S. (1993). Confidence intervals for motion and deformation of the Juan de Fuca. J. Geophys. Res. 98, 16053-16071.

Wittmann, H., von Blanckenburg, F., Kruesmann, T., Norton, K.P.\& Kubik, P.W. (2007). Relation between rock uplift and denudation from cosmogenic nuclides in river sediment in the Central Alps of Switzerland. Journal of Geophysical Research, 112, F04010. DOI: 10.1029/2006JF000729. 
Zachos, J., Pagani, M., Sloan, L., Thomas, E. \& Billups, K. (2001). Trends, rythms and aberrations in global climate 65 my to present. Science, 292, 686-693.

Zagwijn, W.H. \& Doppert, J.W. (1978). Upper Cenozoic of the southern North Sea Basin: Palaeoclimatic and palaeogeographic evolution. Geol. Mijnbouw, 57, 577-588.

Zagwijn, W.H. (1989). The Netherlands during the Tertiary and the Quaternary: A case history of Coastal Lowland evolution. Geol. Mijnbouw, 68, 107-120.

Zhang, P., Molnar, P. \& Downs, W.R. (2001). Increased Sedimentation rates and grain sizes 2-4 Myr ago due to the influence of climate change on erosion rates. Nature, 410, 891-897.

Ziegler, P. \& Fraefel, M. (2009). Response of drainage systems to Neogene evolution of the Jura fold-thrust belt and Upper Rhine Graben. Swiss J. Geosci., 102, 57-75. 


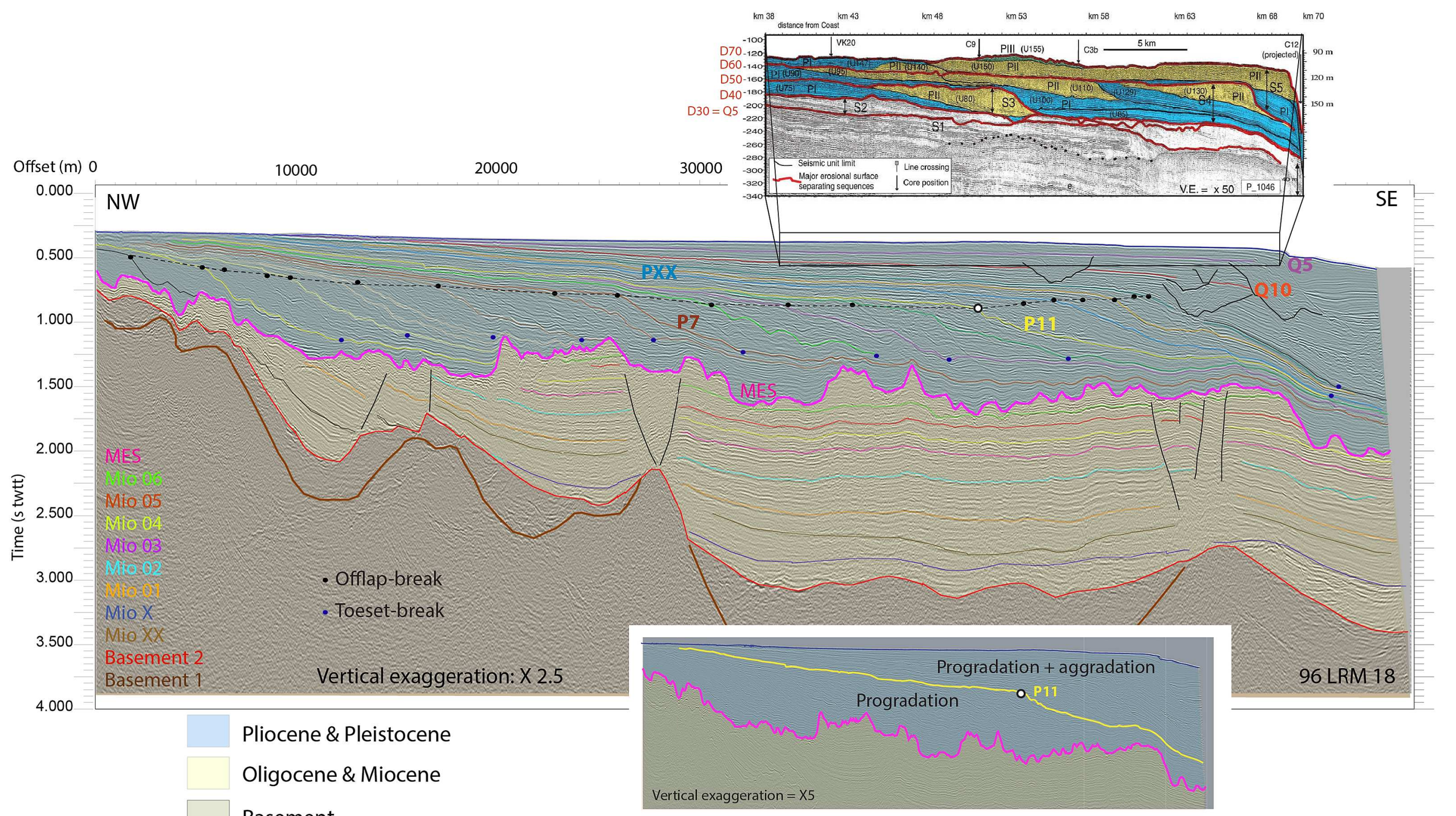
Basement 


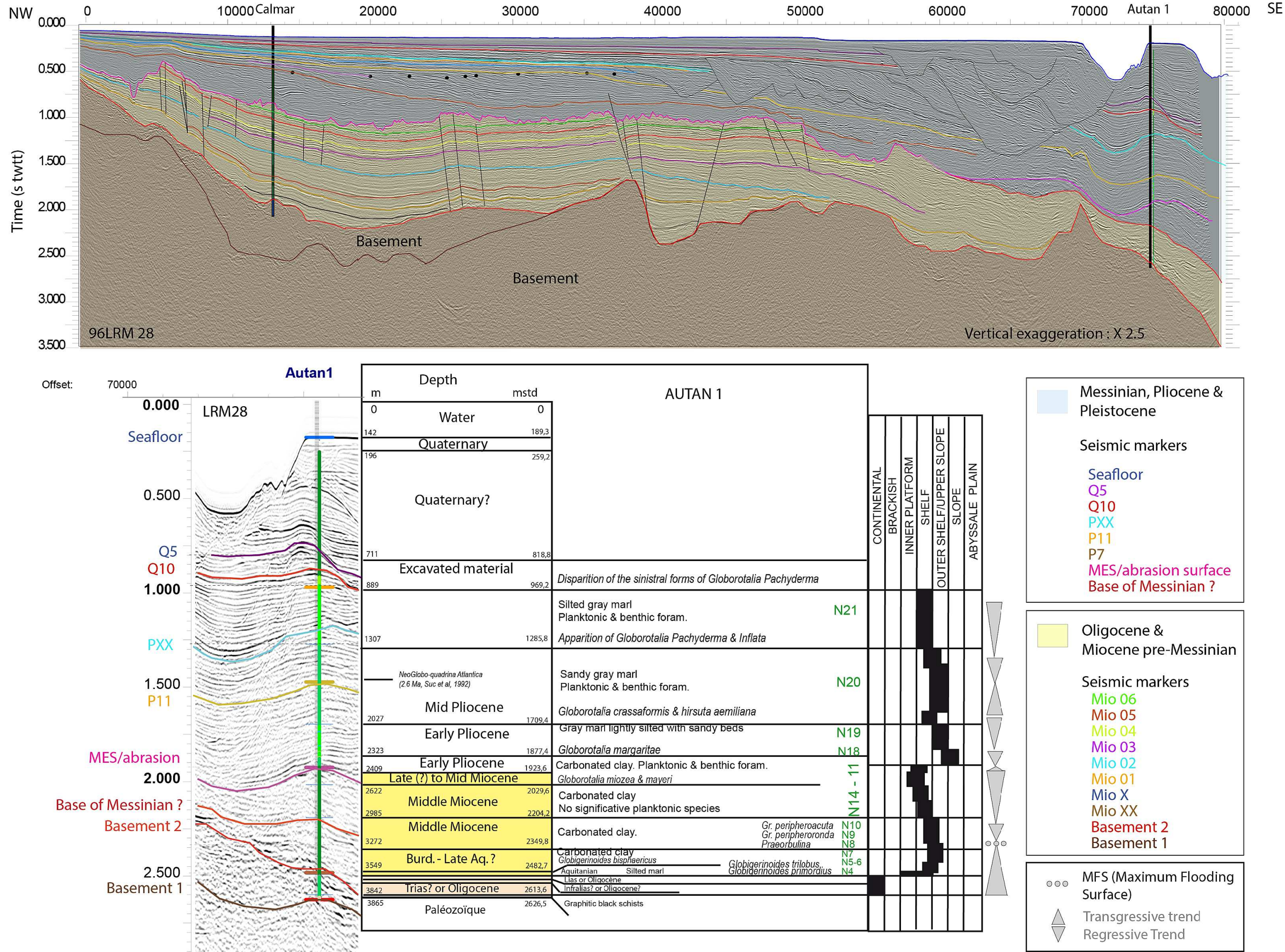

3.000 
NW Offset (km)

$0 \quad 10$

20
30

40

50

50

60

70

80

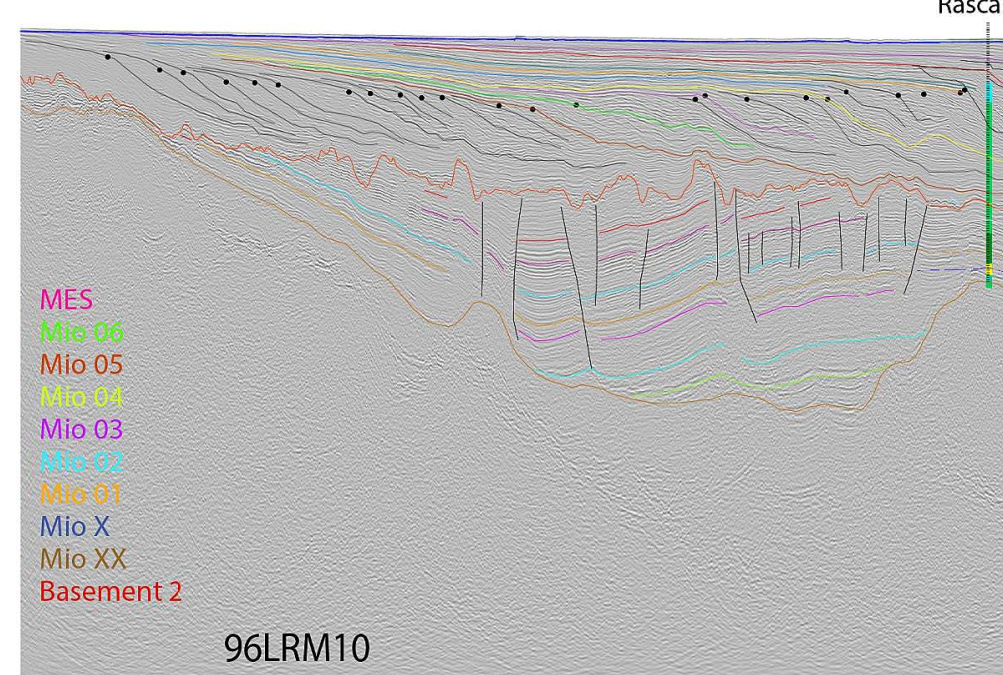

96LRM10

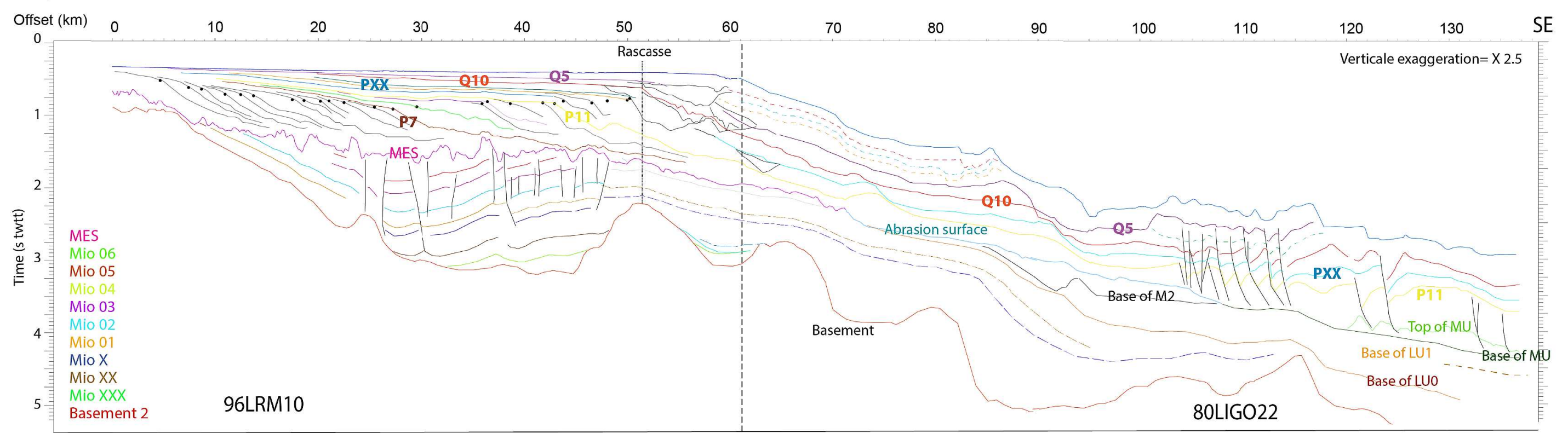




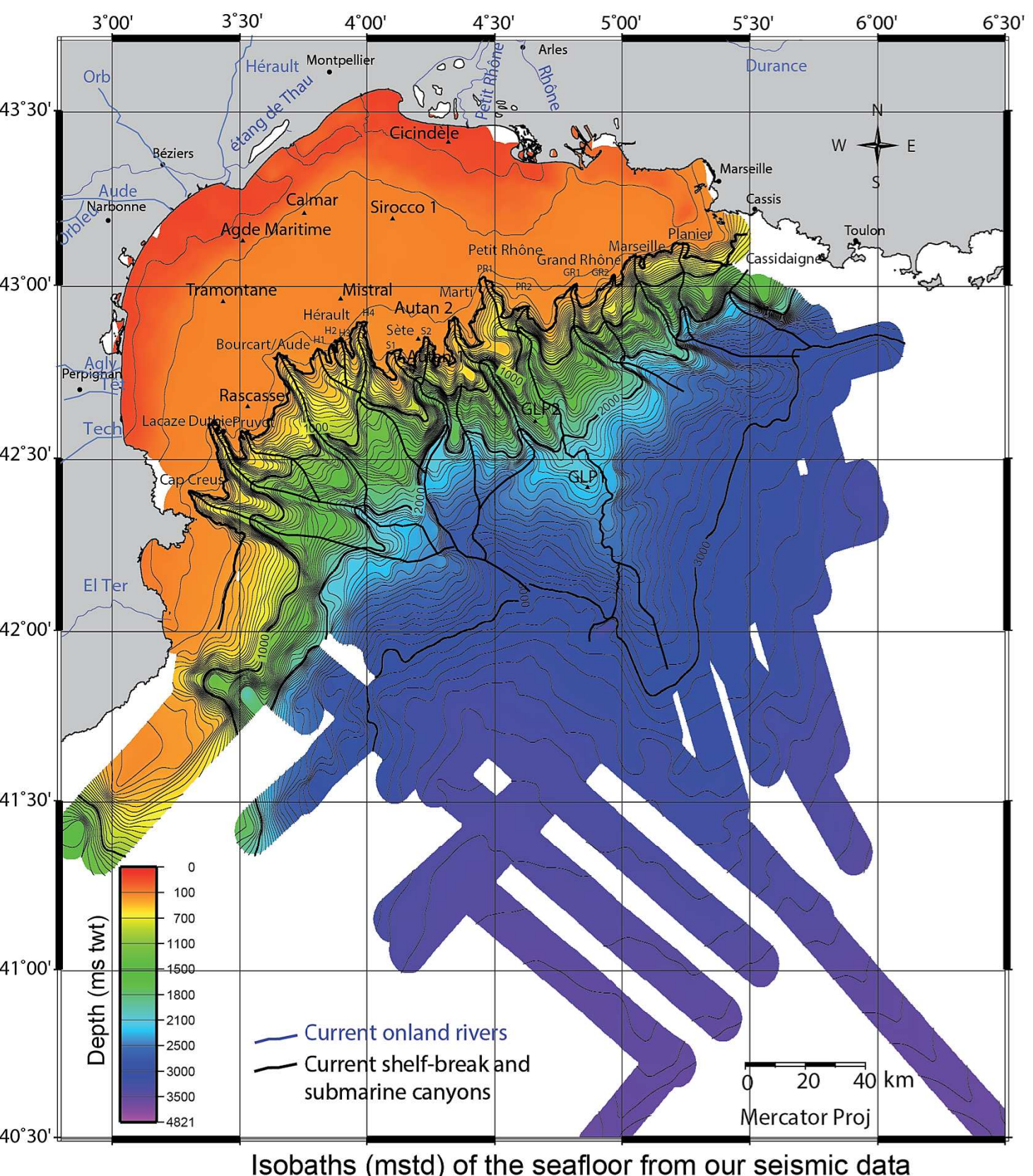

Isobaths (mstd) of the seafloor from our seismic data

Leroux et al., Figure 09

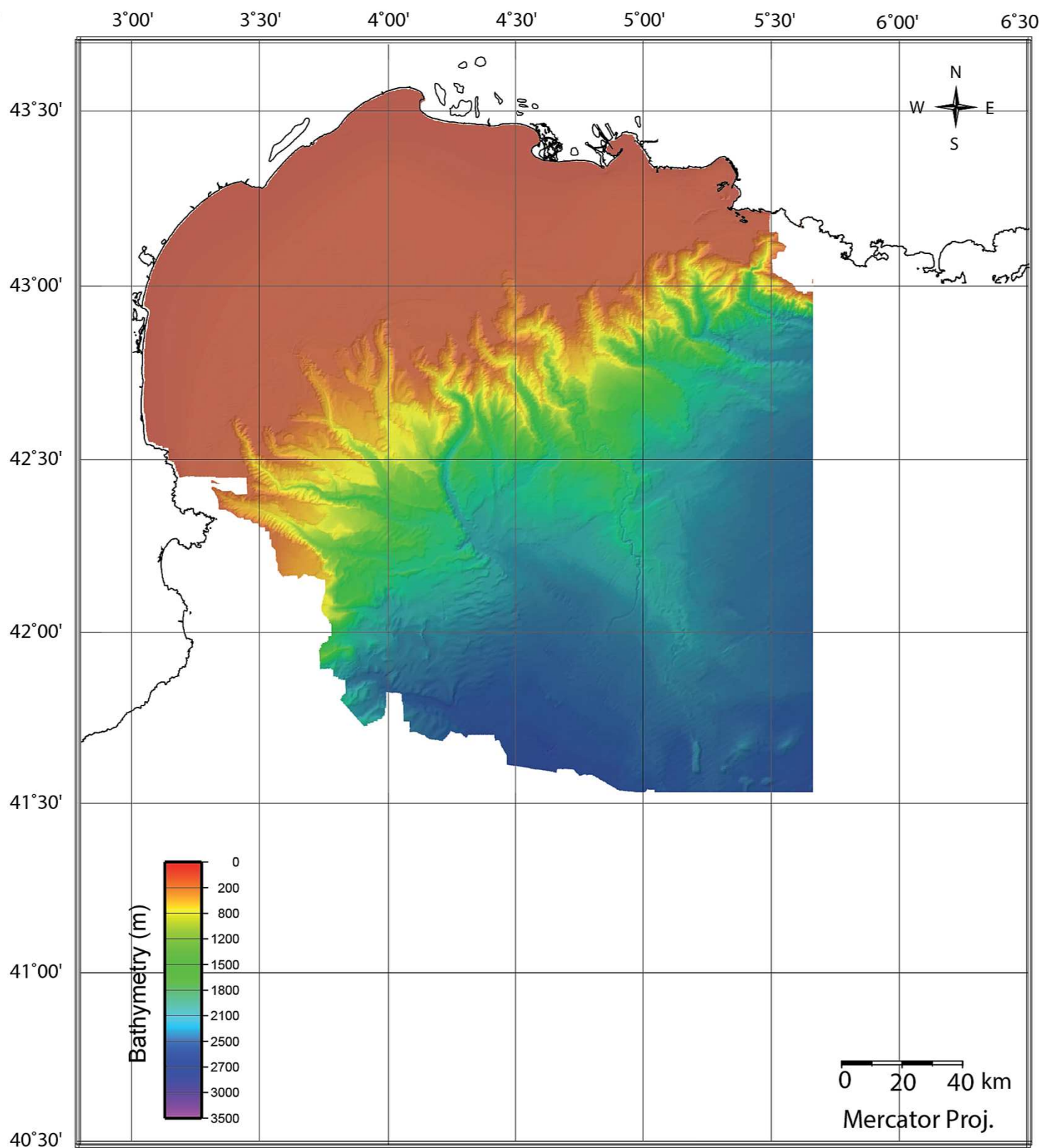

Bathymetric map $(\mathrm{m})$ of the seafloor from a multibeam echosounders compilation (CTDI, Ifremer, 2012) 

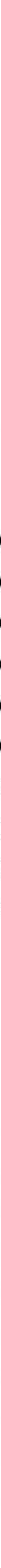


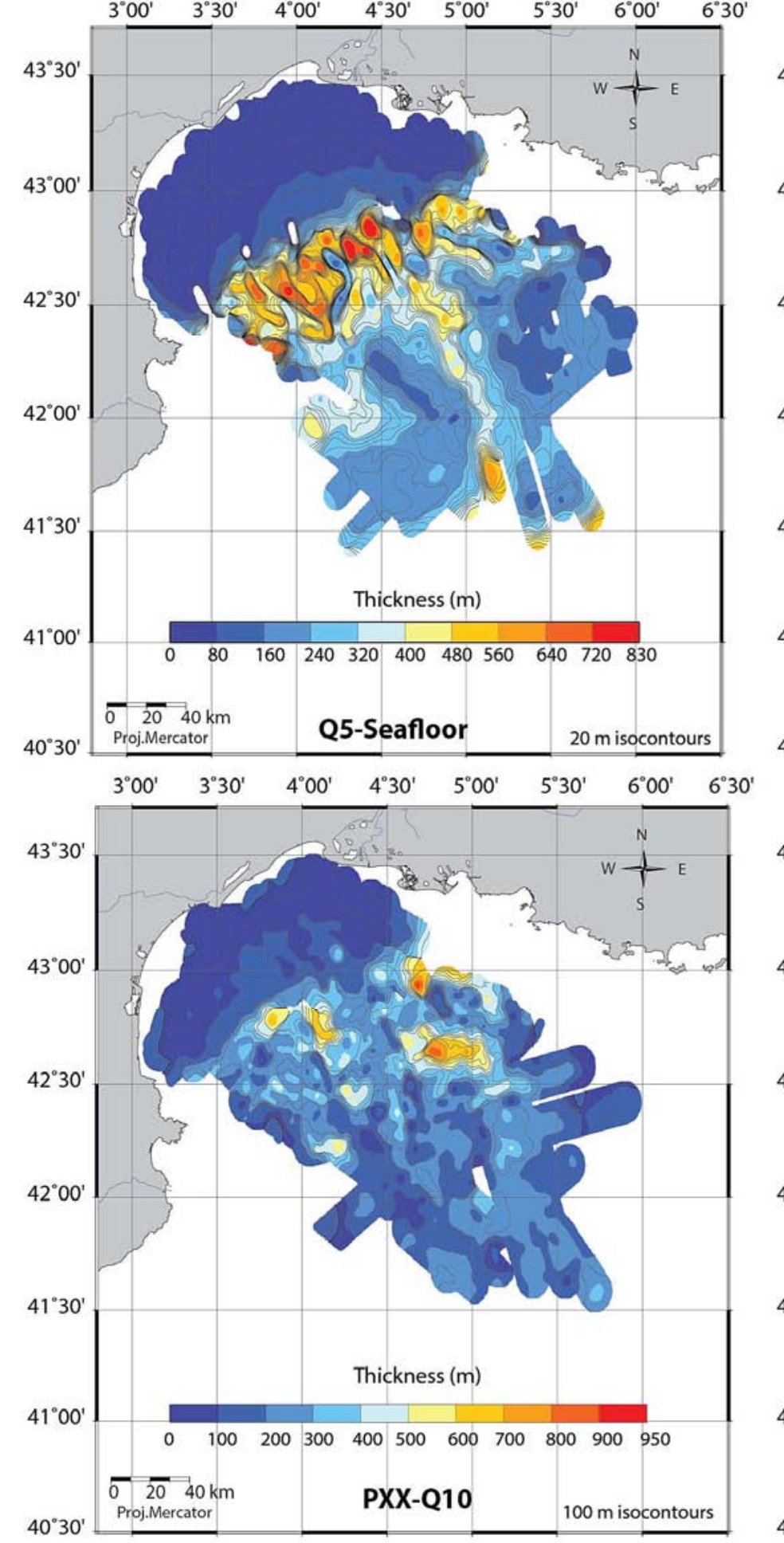

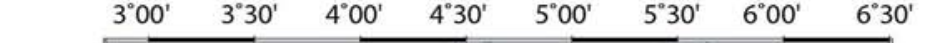
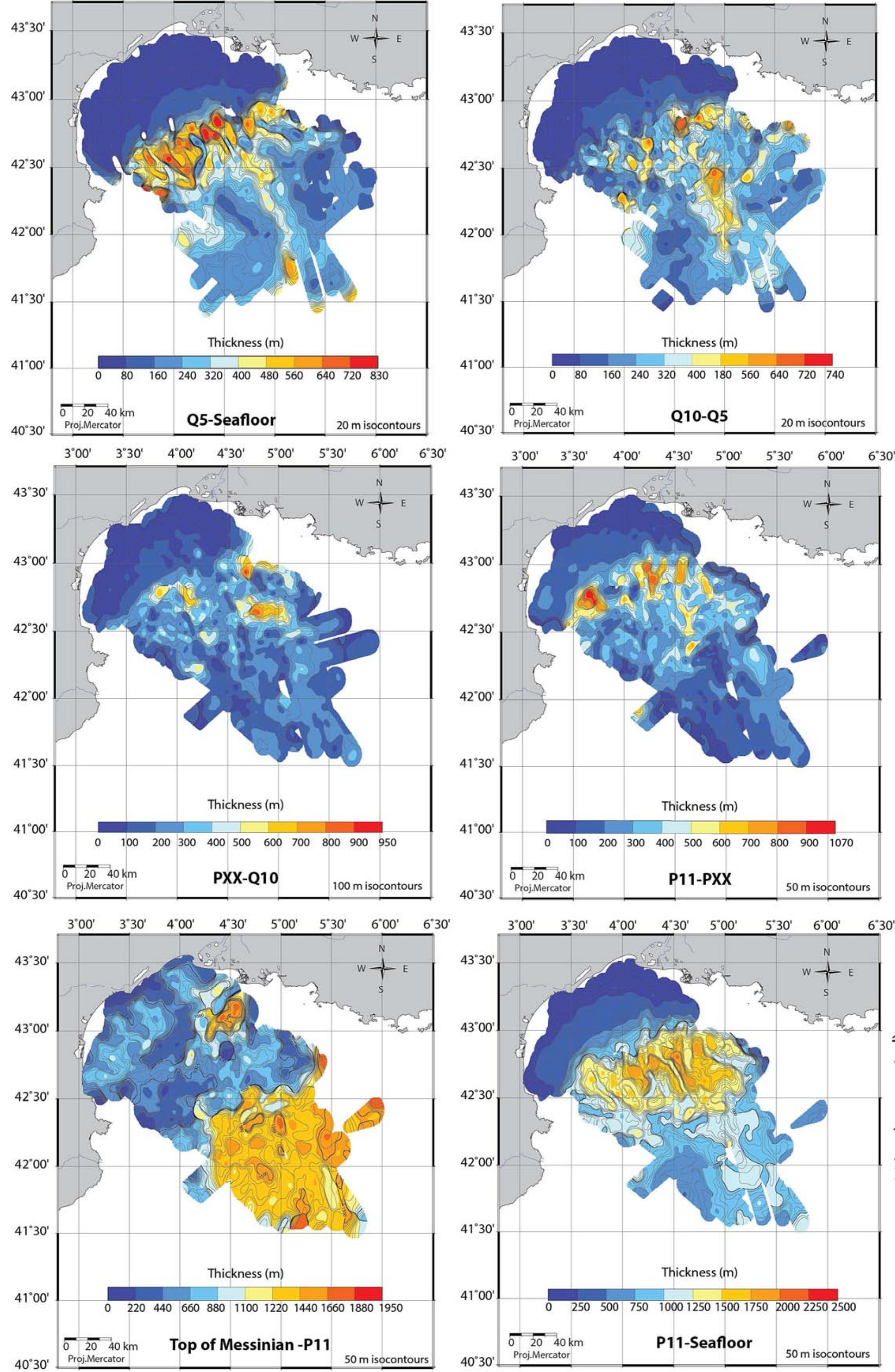

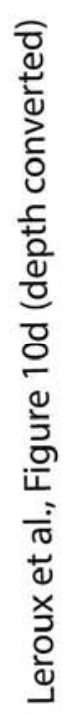




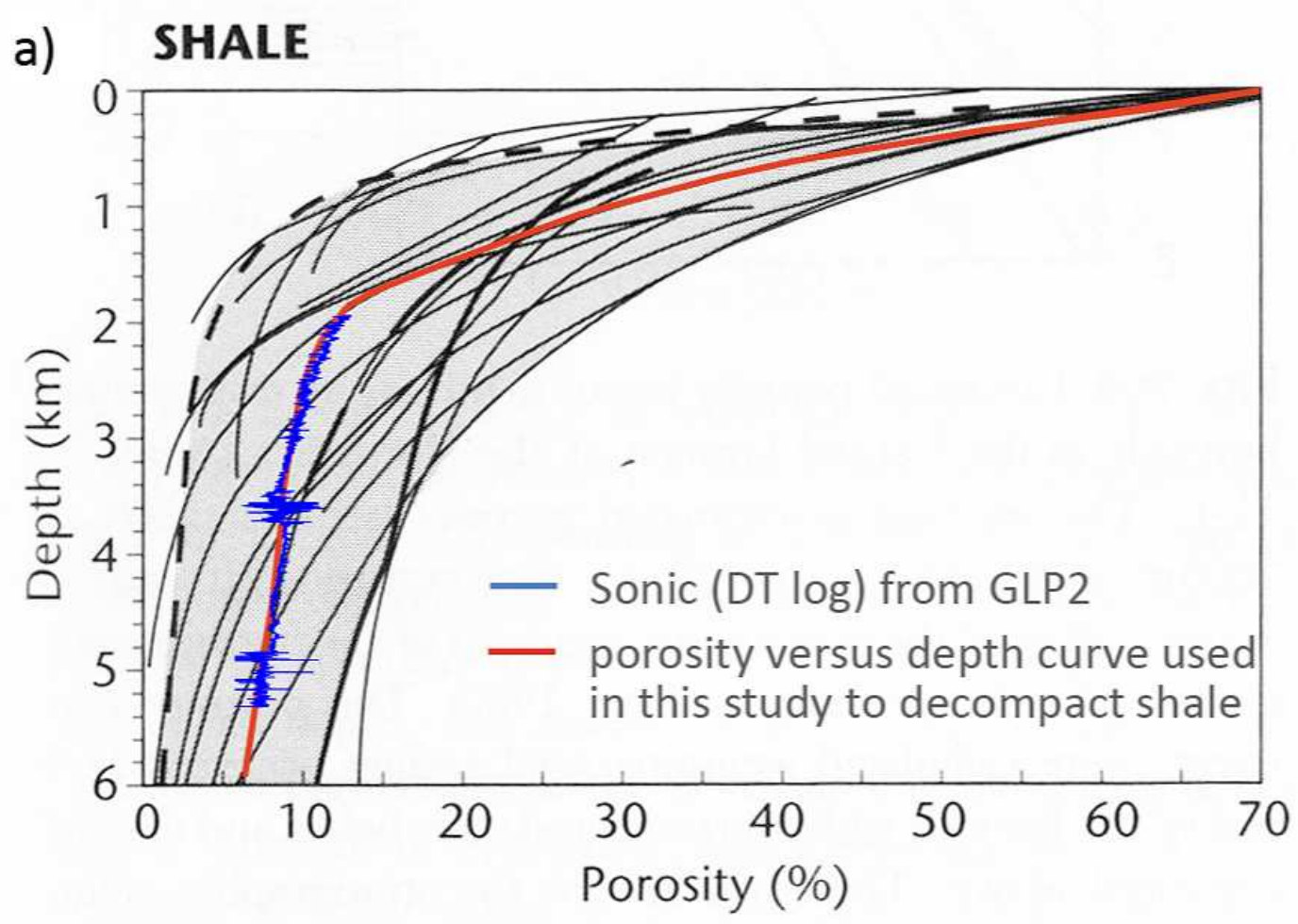

b) SANDSTONE

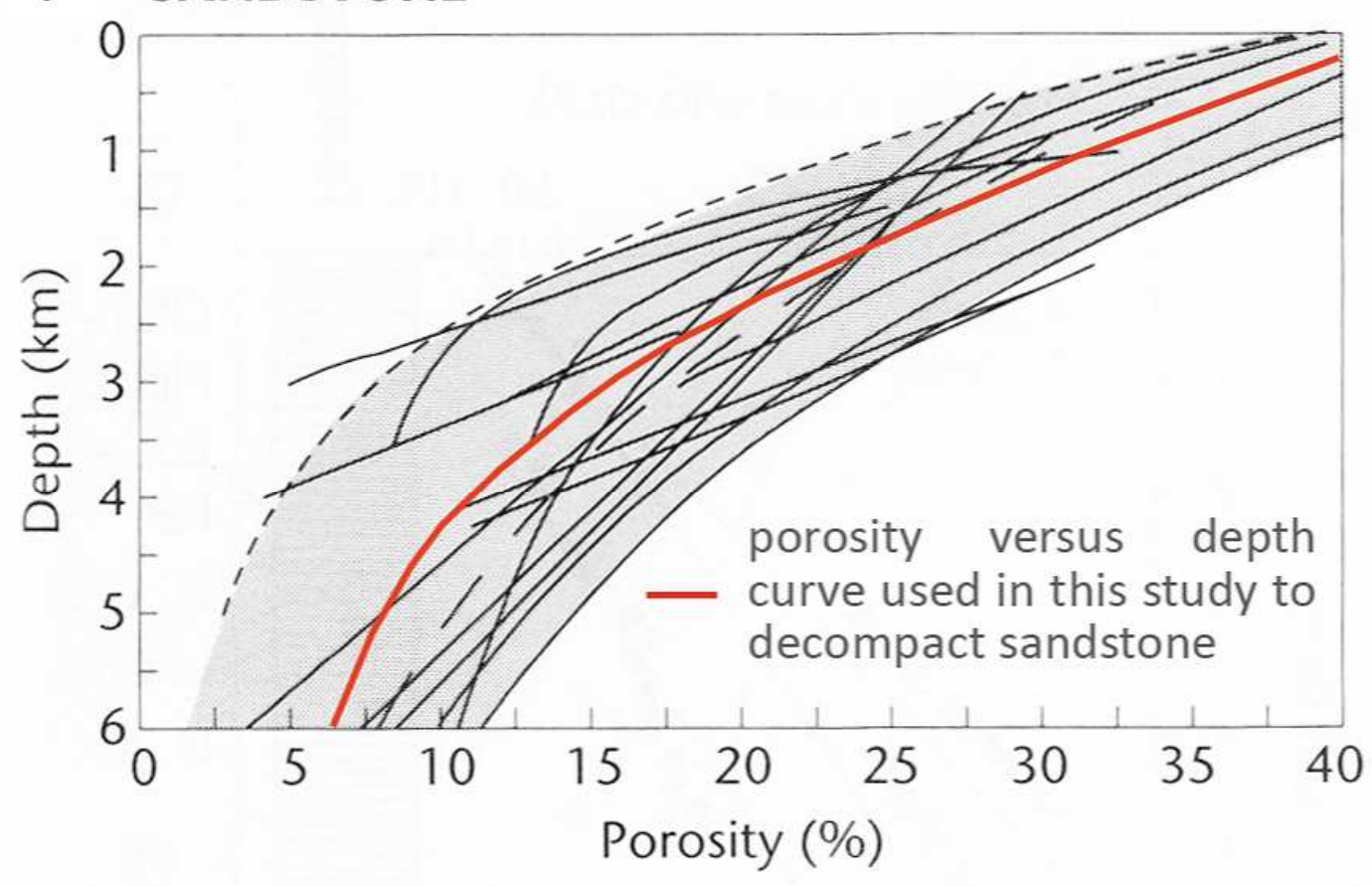

c) CARBONATE

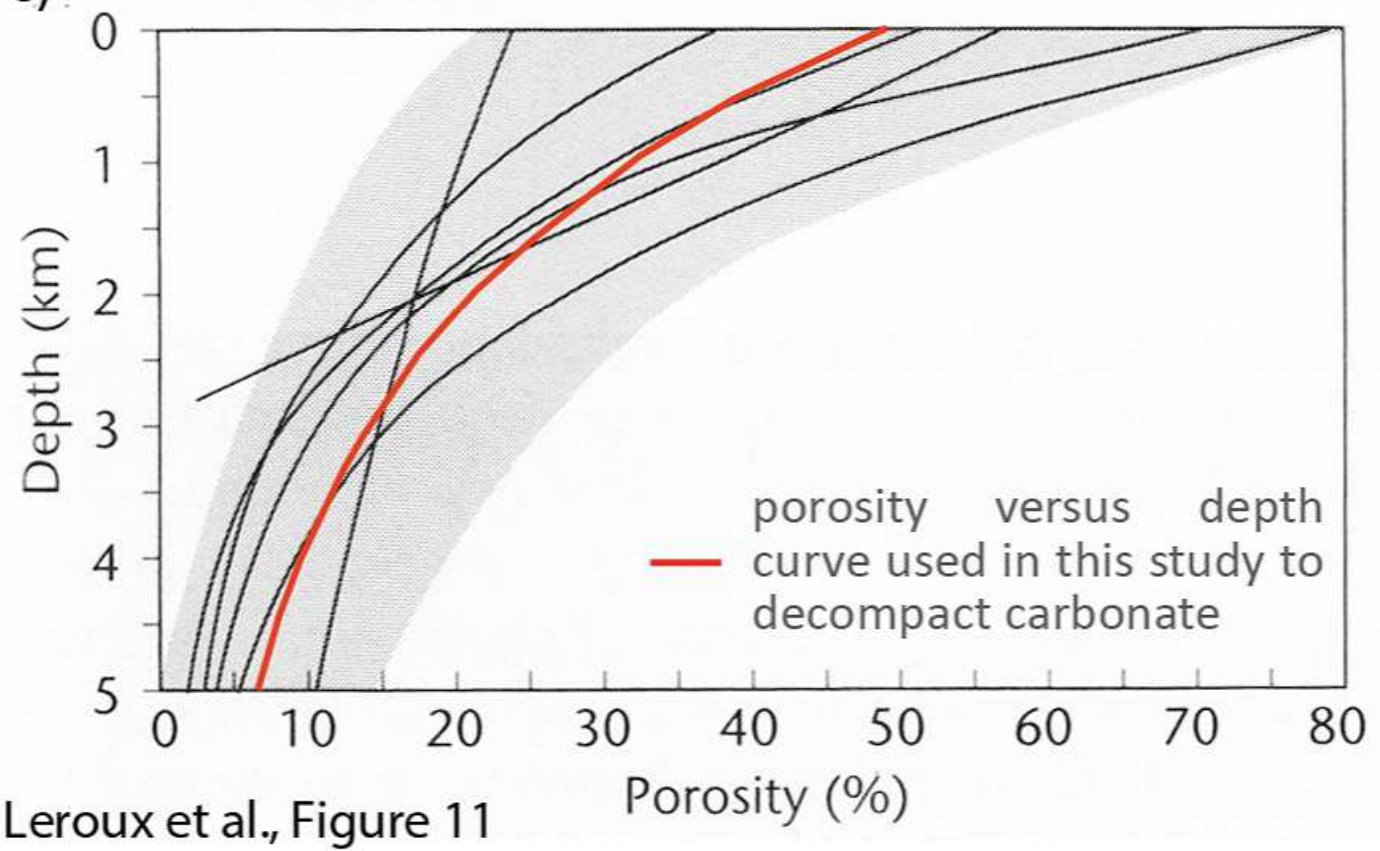


Sediment fluxes $\left(x 10^{3} \mathrm{~km}^{3} / \mathrm{Myr}\right)$

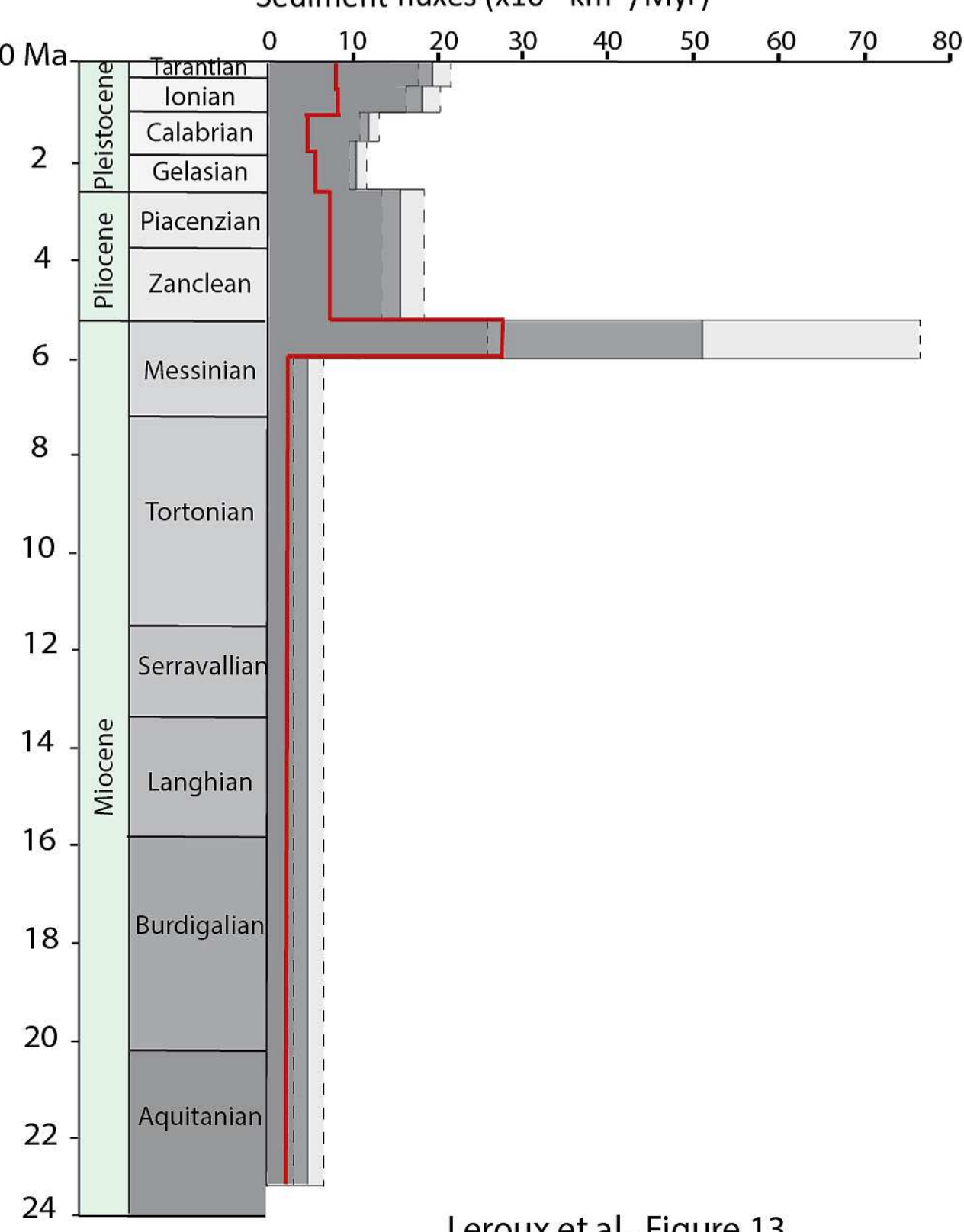

\begin{tabular}{|c|c|c|}
\hline Ages (Ma) & $\begin{array}{c}\text { Uncompacted } \\
\text { sediment volumes }\left(\mathrm{km}^{3}\right)\end{array}$ & $\begin{array}{c}\text { Uncompacted } \\
\text { sediment fluxes }\left(\mathrm{km}^{3} / \mathrm{Myr}\right)\end{array}$ \\
\hline $0.45-0$ & 8,393 & 18,652 \\
\hline $0.90-0.45$ & 8,456 & 18,792 \\
\hline $1.80-0.90$ & 7,079 & 10,112 \\
\hline $2.60-1.80$ & 8,303 & 10,378 \\
\hline $5.33-2.60$ & 35,934 & 13,163 \\
\hline $\begin{array}{l}\text { MSC: } 5.96-5.33 \\
\text { (LU0 +M2+M3) }\end{array}$ & 32,646 & 49,029 \\
\hline Ante-MSC & 49,480 & 2,904 \\
\hline
\end{tabular}

\begin{tabular}{|c|c|c|}
\hline Ages (Ma) & $\begin{array}{c}\text { Sediment volumes } \\
\text { (zero porosity) }\left(\mathrm{km}^{3}\right)\end{array}$ & $\begin{array}{c}\text { Sediment fluxes } \\
\text { (zero porosity) }\left(\mathrm{km}^{3} / \mathrm{Myr}\right)\end{array}$ \\
\hline $0.45-0$ & 3,615 & 8,032 \\
\hline $0.90-0.45$ & 3,822 & 8,456 \\
\hline $1.80-0.90$ & 3,335 & 3,705 \\
\hline $2.60-1.80$ & 4,065 & 5,082 \\
\hline $5.33-2.60$ & 20,120 & 7,370 \\
\hline $\begin{array}{l}\text { MSC: } 5.96-5.33 \\
\text { (LU0 +M2+M3) }\end{array}$ & 19,754 & 28,220 \\
\hline Ante-MSC & 29,434 & 1,724 \\
\hline
\end{tabular}




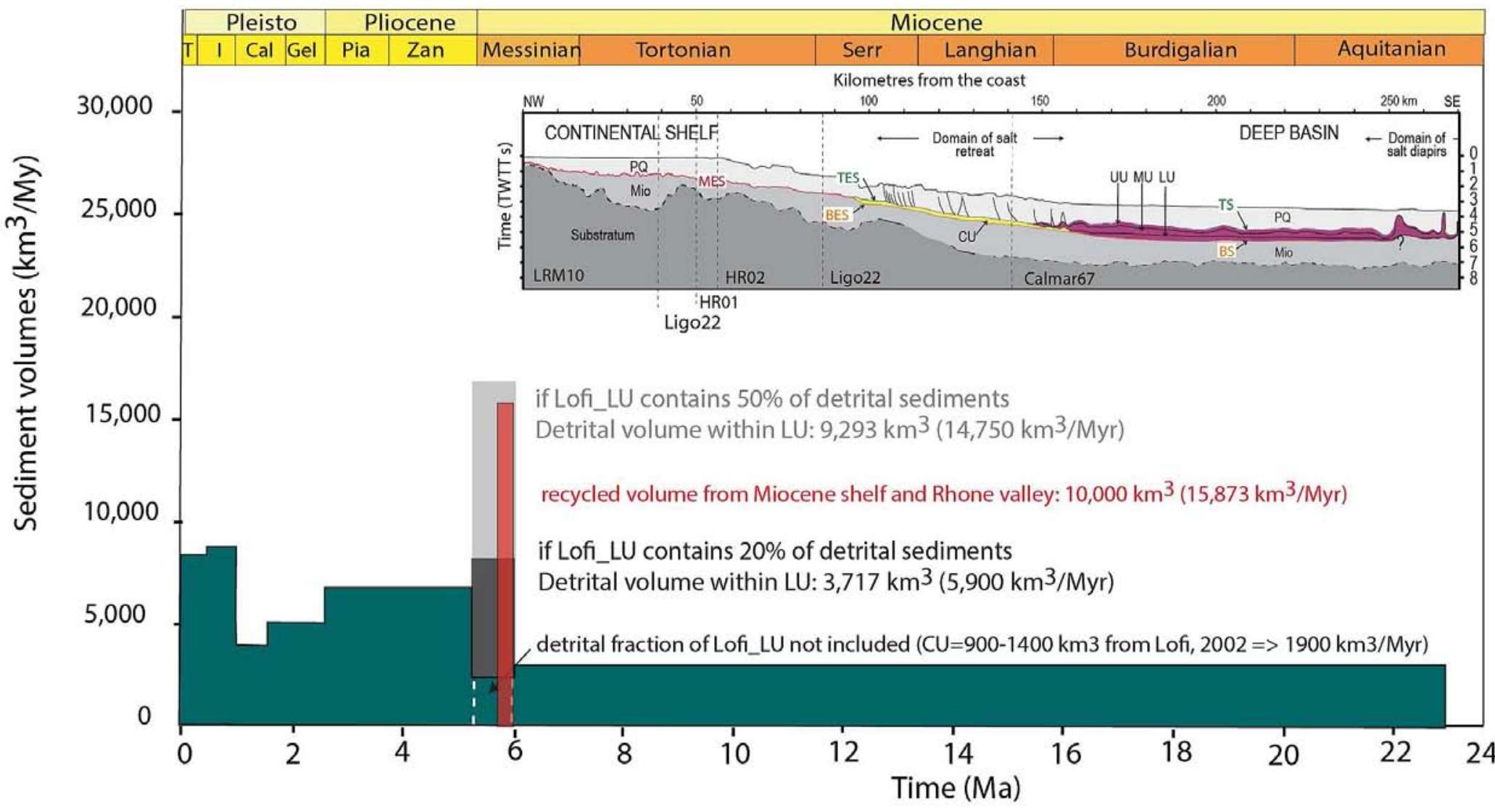

B) Bache et al. (2009) interpretation

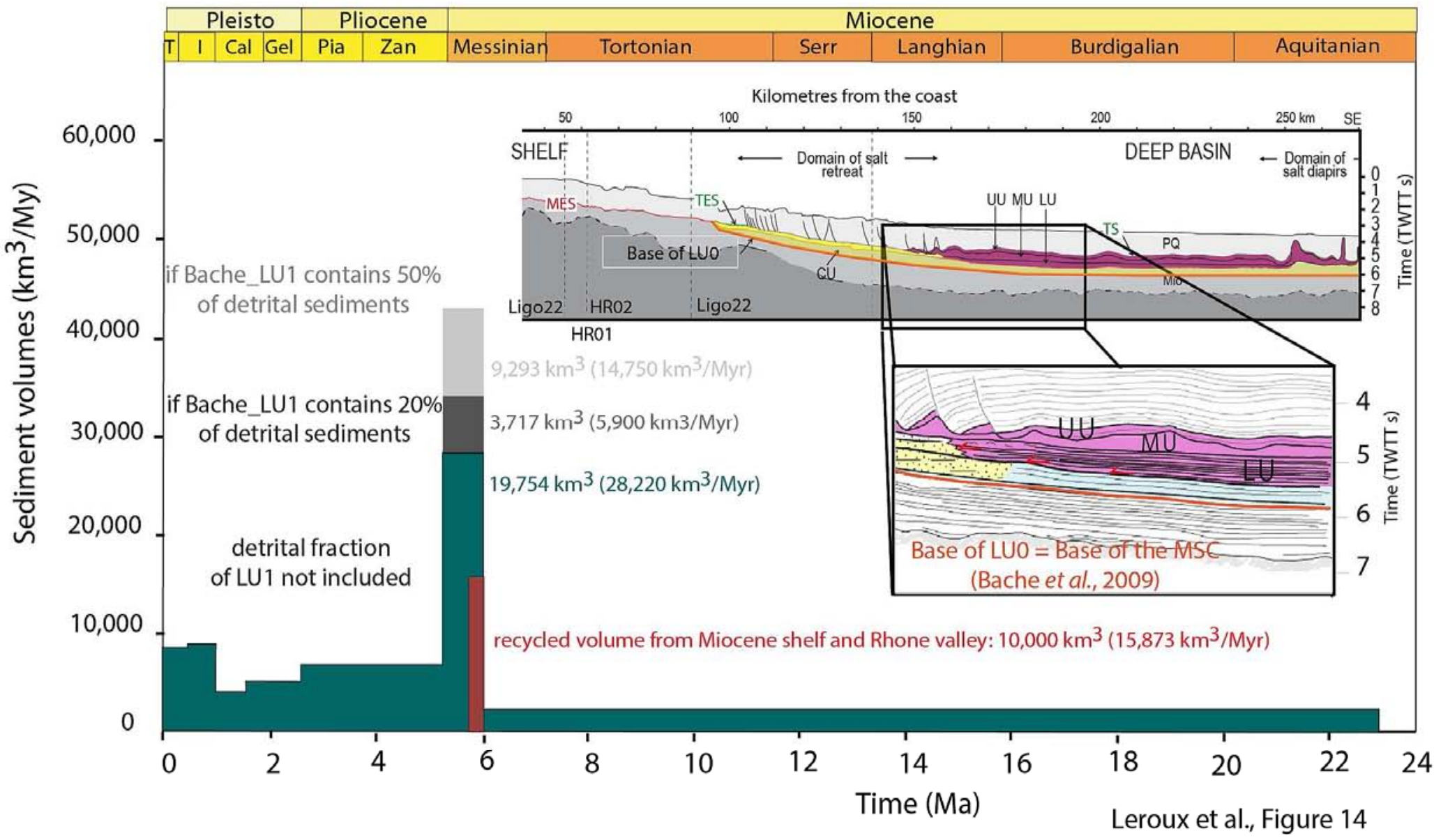




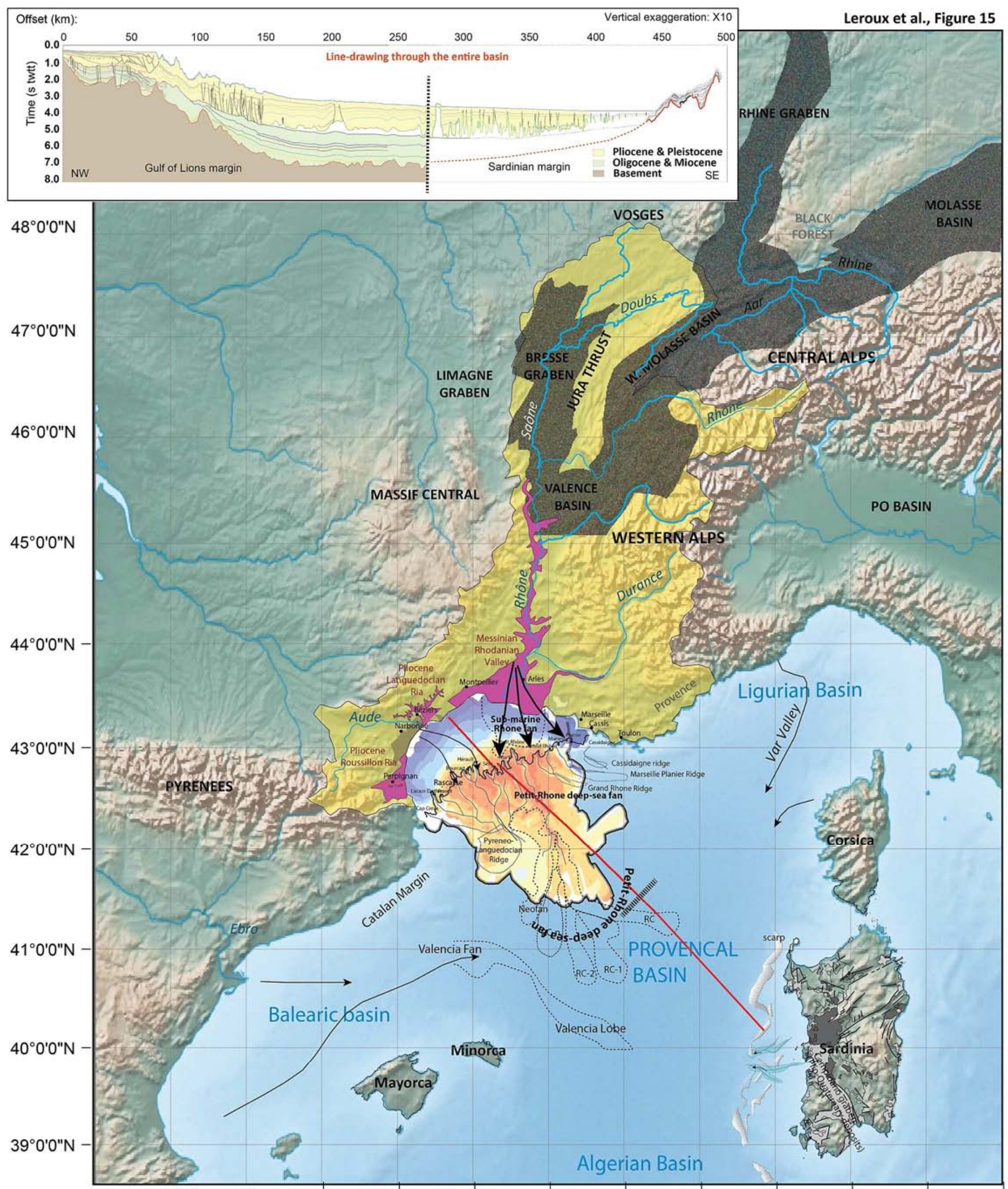

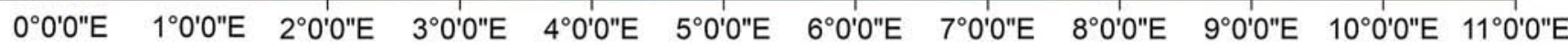




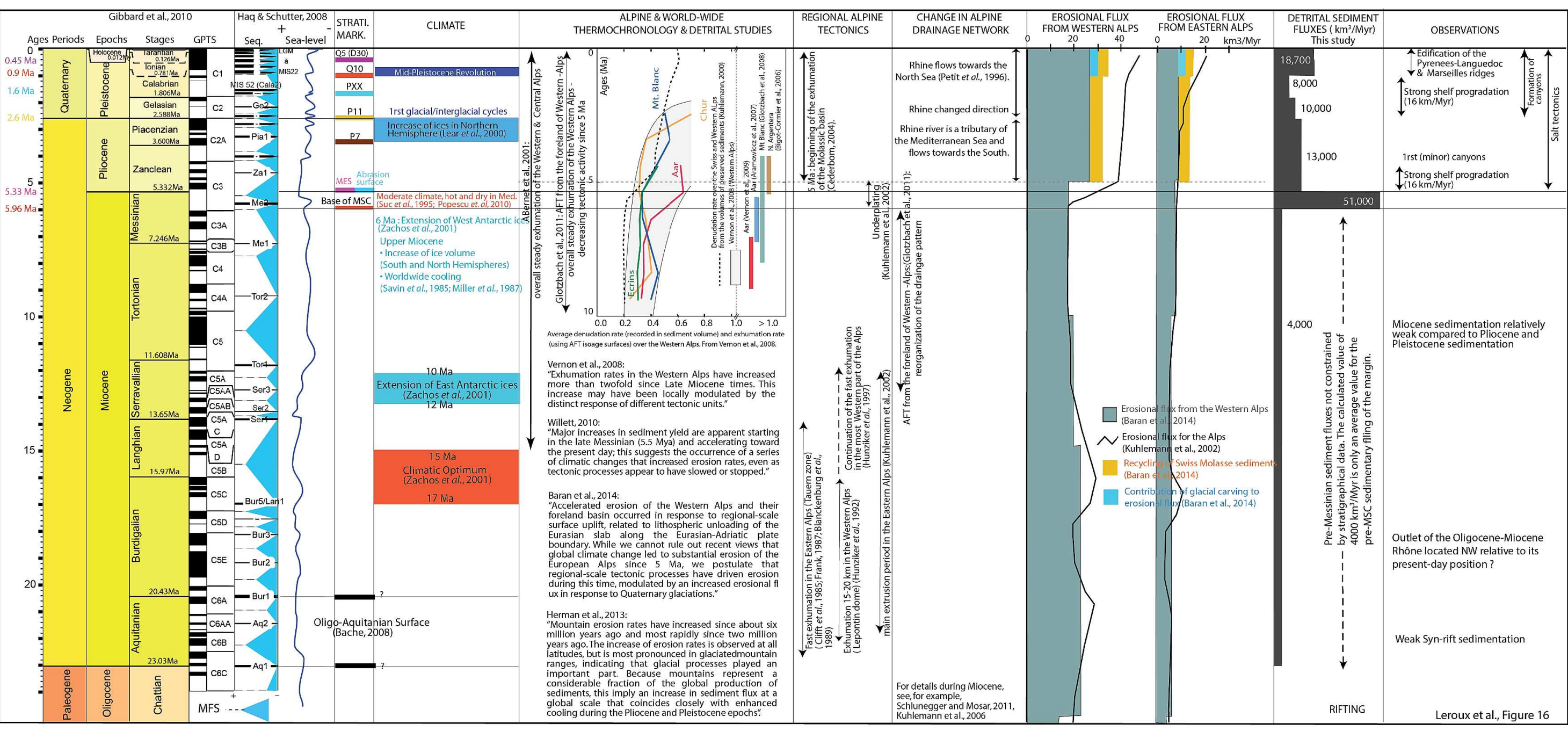



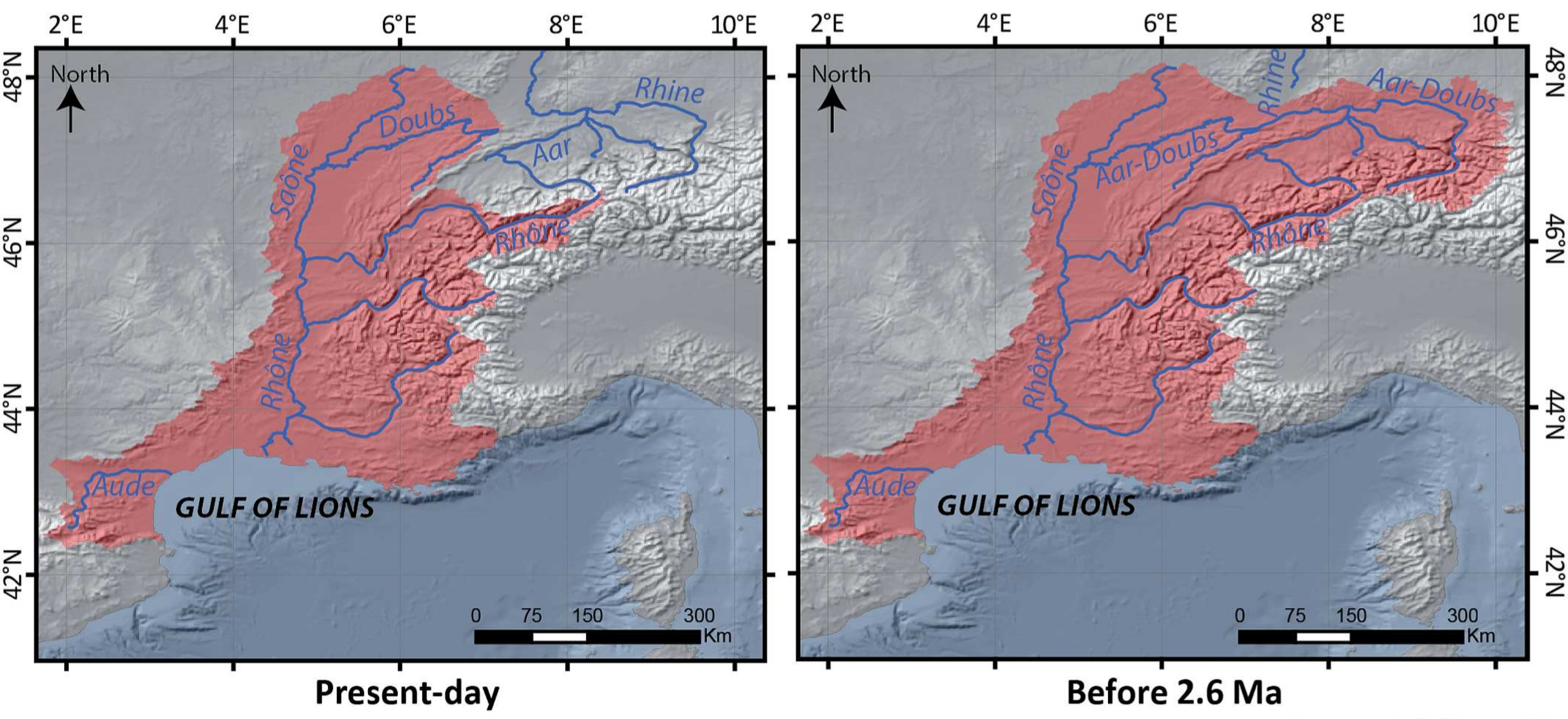

Before 2.6 Ma

Leroux et al., Figure 17 


\begin{tabular}{|c|c|c|c|c|c|c|c|c|c|}
\hline \multirow{2}{*}{$\begin{array}{c}\text { Seismic } \\
\text { discontinuities }\end{array}$} & \multirow{2}{*}{$\begin{array}{l}\text { Seismic } \\
\text { units }\end{array}$} & \multirow{2}{*}{$\begin{array}{l}\text { Seismic } \\
\text { facies }\end{array}$} & \multicolumn{4}{|c|}{ Location and Observations } & \multirow{2}{*}{\begin{tabular}{|c|}
$\begin{array}{c}\text { Ages } \\
\text { (known } \\
\text { or supposed) }\end{array}$ \\
\end{tabular}} & \multirow{2}{*}{ Interpretations } & \multirow{2}{*}{$\begin{array}{l}\text { Sea-level relative } \\
\text { to present-day } \\
\text { (Rabineau et al., } \\
\text { 2006) }\end{array}$} \\
\hline & & & Shelf & Slope & Foot of slope & Basin & & & \\
\hline Sea-floor & _- & - & - & - & - & - & $0 \mathrm{Ma}$ & - & $0 \mathrm{~m}$ \\
\hline D70 - LGM & - & \multicolumn{3}{|c|}{ Erosive Discontinuity } & \multirow{4}{*}{\multicolumn{2}{|c|}{$\begin{array}{l}\text { - Channel/levee complexes with high } \\
\text { seismic central facies (filling of the } \\
\text { channel) and a bedded convergent } \\
\text { lateral facies (levee) }\end{array}$}} & $20 \mathrm{ka}$ & $\begin{array}{l}\text { Low stand } \\
\text { at MIS } 2\end{array}$ & $-100 m$ \\
\hline- & D60-Sea-Floor & \begin{tabular}{|c|} 
regular \\
bedded facies
\end{tabular} & - & - & & & $\begin{array}{l}{[0.14-} \\
0.02 \mathrm{Ma}] \\
\end{array}$ & & - \\
\hline D60 & - & \multicolumn{3}{|c|}{ Erosive Discontinuity } & & & $140 \mathrm{ka}$ & $\begin{array}{l}\text { Low stand } \\
\text { at MIS } 6\end{array}$ & $-95 m$ \\
\hline- & D50-D60 & \begin{tabular}{|c|} 
regular \\
bedded facies
\end{tabular} & - & - & & & $\begin{array}{l}{[0.25-} \\
0.14 \mathrm{Ma}] \\
\end{array}$ & & - \\
\hline D50 & - & \multicolumn{3}{|c|}{ Erosive Discontinuity } & \multirow{2}{*}{\multicolumn{2}{|c|}{$\begin{array}{l}\text { - Presence of lobes with some chaotic } \\
\text { facies at the outlets of channels }\end{array}$}} & $250 \mathrm{ka}$ & $\begin{array}{l}\text { Low stand } \\
\text { at MIS } 8\end{array}$ & $-90 m$ \\
\hline- & D40-D50 & \begin{tabular}{|c|} 
regular \\
bedded facies
\end{tabular} & - & - & & & $\begin{array}{l}{[0.34-} \\
0.25 \mathrm{Ma}] \\
\end{array}$ & & - \\
\hline D40 & - & \multicolumn{3}{|c|}{ Erosive Discontinuity } & \multirow{6}{*}{\multicolumn{2}{|c|}{$\begin{array}{l}\text { - Punctual shifts of reflectors by listric } \\
\text { faults }\end{array}$}} & $340 \mathrm{ka}$ & $\begin{array}{l}\text { Low stand } \\
\text { at MIS } 10\end{array}$ & $-160 m$ \\
\hline- & D30-D40 & $\begin{array}{l}\text { regular } \\
\text { bedded } \\
\text { facies }\end{array}$ & - & - & & & $\begin{array}{l}{[0.45-} \\
0.34 \mathrm{Ma}] \\
\end{array}$ & & - \\
\hline D30 / Q5 & - & \multicolumn{3}{|c|}{ Erosive Discontinuity with high amplitude } & & & $450 \mathrm{ka}$ & $\begin{array}{l}\text { Low stand } \\
\text { at MIS } 12\end{array}$ & $-160 m$ \\
\hline- & Q10-Q5 & $\begin{array}{l}\text { regular } \\
\text { bedded } \\
\text { facies }\end{array}$ & $\begin{array}{c}\text { progradational- } \\
\text { aggradational } \\
\text { prisms }\end{array}$ & $\begin{array}{l}\text { aggradation and } \\
\text { internal erosional } \\
\text { surfaces }\end{array}$ & & & $\begin{array}{l}\{0.9- \\
0.45 \mathrm{Ma}]\end{array}$ & & - \\
\hline Q10 & - & \multicolumn{3}{|c|}{ Erosive Discontinuity with high amplitude } & & & $0.9 \mathrm{Ma}$ & Low stand & $?$ \\
\hline- & PXX-Q10 & $\begin{array}{l}\text { regular } \\
\text { bedded } \\
\text { facies }\end{array}$ & \begin{tabular}{|c|}
$\begin{array}{c}\text { progradational- } \\
\text { aggradational } \\
\text { prisms }\end{array}$ \\
\end{tabular} & $\begin{array}{c}\text { aggradation and } \\
\text { internal erosional } \\
\text { surfaces } \\
\end{array}$ & & & {$[1.8-0.9 \mathrm{Ma}]$} & & - \\
\hline PXX & - & \multicolumn{5}{|c|}{ Erosive Discontinuity with high amplitude } & $1.6-1.8 \mathrm{Ma}$ & Low stand & ? \\
\hline- & P11-PXX & $\begin{array}{l}\text { regular } \\
\text { bedded } \\
\text { facies }\end{array}$ & \begin{tabular}{|c|}
$\begin{array}{c}\text { progradational- } \\
\text { aggradational } \\
\text { prisms }\end{array}$ \\
\end{tabular} & $\begin{array}{c}\text { aggradation and } \\
\text { internal erosional } \\
\text { surfaces } \\
\end{array}$ & $\begin{array}{l}\text { aggradation with } \\
\text { channel tracks }\end{array}$ & $\begin{array}{l}\text { aggradation with } \\
\text { channel tracks }\end{array}$ & $\begin{array}{l}{[2.60-} \\
1.60 \mathrm{Ma}]\end{array}$ & & - \\
\hline P11 & - & \multicolumn{5}{|c|}{ Erosive Discontinuity with high amplitude } & $2.6 \mathrm{Ma}$ & Low stand & ? \\
\hline- & P07-P11 & $\begin{array}{l}\text { regular } \\
\text { bedded } \\
\text { facies }\end{array}$ & \begin{tabular}{|l} 
Progradational \\
prisms
\end{tabular} & aggradation & aggradation & aggradation & {$[3.8-2.6 \mathrm{Ma}]$} & & - \\
\hline P07 & - & & \multicolumn{4}{|c|}{ Erosive Discontinuity with high amplitude } & 3.8-3.2 Ma & \begin{tabular}{|l|}
$\begin{array}{l}\text { Sea-level fall Pia } 1 \\
\text { from Haq et al., } 2008 \\
\end{array}$ \\
\end{tabular} & $?$ \\
\hline- & MES-P07 & $\begin{array}{l}\text { regular } \\
\text { bedded } \\
\text { facies }\end{array}$ & $\mid \begin{array}{l}\text { Progradational } \\
\text { prisms }\end{array}$ & aggradation & aggradation & $\begin{array}{c}\text { aggradation } \\
\text { without } \\
\text { channel tracks }\end{array}$ & {$[5.33-3.8 \mathrm{Ma}]$} & & - \\
\hline $\begin{array}{c}\text { Messinian } \\
\text { Erosional } \\
\text { Surface (pink) }\end{array}$ & - & $\begin{array}{l}\text { Rough erosive } \\
\text { discontinuity }\end{array}$ & $\begin{array}{c}\text { Below the Plio- } \\
\begin{array}{c}\text { Pleistocene } \\
\text { depōsits }\end{array}\end{array}$ & $\begin{array}{l}\text { Below the Plio- } \\
\text { Pleistocene deposits }\end{array}$ & - & - & \begin{tabular}{l|} 
diachron \\
surface: 5.96 \\
Ma \& $5.3 \mathrm{Ma}$ \\
\end{tabular} & $\begin{array}{c}\begin{array}{c}\text { Fluviatile erosional } \\
\text { surface linked to the } \\
\text { MSC sea-level } \\
\text { fall }\end{array} \\
\end{array}$ & - \\
\hline $\begin{array}{c}\text { Ravinement } \\
\text { Surface (RS) } \\
\text { Turquoise-blue }\end{array}$ & - & \multicolumn{2}{|c|}{ Flat discontinuity } & $\begin{array}{l}\text { - lateral passage with } \\
\text { the MES } \\
\text {-conformal with } \\
\text { Miocene series } \\
\end{array}$ & $\begin{array}{l}\text { in continuity with } \\
\text { the top of } \mathrm{M} 2\end{array}$ & - & $\begin{array}{l}5,46 \mathrm{Ma} \\
5.33 \mathrm{Ma}\end{array}$ & \begin{tabular}{|l|} 
Marine abrasion \\
surface (flatten by \\
the waves)
\end{tabular} & \\
\hline M3 unit & $\begin{array}{l}\text { Chaotic and } \\
\text { transparent }\end{array}$ & - & - & $\begin{array}{l}\text { - Above M2 unit } \\
\text { - Downstream } \\
\text { extension limited by } \\
\text { listric faults } \\
\text { - lateral passage with } \\
\text { MU and UU }\end{array}$ & - & & $\begin{array}{l}\text { Later } \\
\text { than } 5.46 \mathrm{Ma}\end{array}$ & Detrital & $\begin{array}{l}\text { Abrasion } \\
\text { residuals }\end{array}$ \\
\hline M2 unit & $\begin{array}{l}\text { Chaotic, more } \\
\text { or less } \\
\text { transparent }\end{array}$ & - & - & $\begin{array}{l}\text { - Base of } \mathrm{M} 2 \text { erosive } \\
\text { - below the } \\
\text { Plio-Pleistocene } \\
\text { deposits }\end{array}$ & $\begin{array}{l}\text { - Top of M2 in the } \\
\text { prologation of the } \\
\text { RS } \\
\text { - Lateral passage } \\
\text { with the base of } \\
\text { MU? or below } \\
\text { MU? }\end{array}$ & $\begin{array}{l}\text { - Lateral passage } \\
\text { with MU or above } \\
\text { the terlinal part of } \\
\text { LU? } \\
\text { - Above the LUO }\end{array}$ & $\begin{array}{c}{[5.96-} \\
5.33 \mathrm{Ma}]\end{array}$ & Detrital & $\begin{array}{l}\text { Later } \\
\text { products of } \\
\text { messinian } \\
\text { erosion }\end{array}$ \\
\hline $\begin{array}{l}\text { Upper Unit } \\
\text { (UU) }\end{array}$ & $\begin{array}{l}\text { Conti- } \\
\text { nuous-subco } \\
\text { ntinuous } \\
\text { reflectors } \\
\text { with high } \\
\text { amplitude }\end{array}$ & - & - & - & \multicolumn{2}{|c|}{$\begin{array}{l}\text { - Below Plio-Pleistocene deposits } \\
\text { - Above MU }\end{array}$} & $\begin{array}{c}{[5.96-} \\
5.33 \mathrm{Ma}]\end{array}$ & Evaporitic & $\begin{array}{l}\text { Upper } \\
\text { evaporites }\end{array}$ \\
\hline $\begin{array}{l}\text { Mobile Unit } \\
\text { (MU) }\end{array}$ & Transparent & - & - & - & $\begin{array}{l}\text { - Above M0, M1 } \\
\text { - stratigraphic level } \\
\text { with RS or top of } \\
\text { M2 }\end{array}$ & $\begin{array}{l}\text { - Below the UU } \\
\text { - Above LU1 }\end{array}$ & $\begin{array}{c}{[5.96-} \\
5.33 \mathrm{Ma}]\end{array}$ & Halite & Salt \\
\hline $\begin{array}{l}\text { Lower Unit } \\
\text { (LU1) }\end{array}$ & $\begin{array}{l}\text { Bedded and } \\
\text { continuous } \\
\text { reflectors with } \\
\text { low frequency }\end{array}$ & - & - & - & $\begin{array}{l}\text { - Base of LU } \\
\text { erosive }\end{array}$ & $\begin{array}{l}\text { - Base of LU1 } \\
\text { conformal? }\end{array}$ & $\begin{array}{c}{[5.96-} \\
5.46 \mathrm{Ma}]\end{array}$ & $\begin{array}{l}\text { Detrital \& } \\
\text { evaporitic }\end{array}$ & Early evaporites \\
\hline $\begin{array}{l}\text { Mo, M1, Ma } \\
\text { Units (LU0) }\end{array}$ & Chaotic & - & - & - & $\begin{array}{l}\text { - M0 below M1 } \\
\text { - M0 \& M1 below } \\
\text { M2 } \\
\text { - M1 in lateral } \\
\text { passage with LU1 } \\
\text { in the basin }\end{array}$ & - Ma below LU1 & $\begin{array}{l}{[5.96-} \\
5.46 \mathrm{Ma}]\end{array}$ & Detrital & $\begin{array}{l}\text { Earlier products } \\
\text { of messinian } \\
\text { erosion }\end{array}$ \\
\hline
\end{tabular}




\begin{tabular}{|c|c|c|c|}
\hline Surfaces & Depth intervals (TWTT ms) & Velocities $(\mathrm{m} / \mathrm{s})$ & Remarks \\
\hline Sea-fllor & & $\mathrm{v} 0=1500$ & \\
\hline \multirow{5}{*}{ Q5 - SeaFloor } & $50<z<200$ & 1800 & Average velocities (from Calmar and Tramontane) on the inner shelf \\
\hline & $200<z<825$ & $1800<\mathrm{v}<2200$ & Gradual Increase of velocity (until location of Autan 1) \\
\hline & $825<z<2105$ & 2200 & Maximal velocity at GLP2 \\
\hline & $2105<z<3000$ & $2200>v>2000$ & Gradual decrease of velocity towards the basin (until location of ESP204) \\
\hline & $3000<z<3941$ & 2000 & Average Velocity in the deep basin around ESP $206=2050 \mathrm{~m} / \mathrm{s}$ \\
\hline \multirow{7}{*}{ Q10-Q5 } & $66<z<200$ & 1850 & Average velocities (from wells) on the inner shelf \\
\hline & $200<z<970$ & $1850<v<2300$ & Gradual Increase of velocity (until location of Autan 1 ) \\
\hline & $z=970$ & 2300 & Veolocity measured at Autan 1 \\
\hline & $970<z<1800$ & $2300<v<2700$ & Gradual Increase of velocity until locations of ESP201 \& ESP202 \\
\hline & $\mathrm{z}=1800$ & 2700 & Maximal velocity at ESP201 and around ESP201 \& 202 \\
\hline & $1800<z<3165$ & $2700>v>2500$ & Gradual decrease of velocity towards the basin until location of ESP203 \\
\hline & $3165<z<4121$ & $2500>v>2300$ & Decrease of mean in the basin beyond ESP203 \\
\hline \multirow{3}{*}{ PXX-Q10 } & $z<1000$ & 2200 & Mean velocity on the shelf \\
\hline & $1000<z<3000$ & 3000 & Mean velocity on the slope \\
\hline & $z>3000$ & 2700 & Mean velocity in the basin \\
\hline \multirow{7}{*}{ P11-PXX } & $82<z<1000$ & 2488 & Average velocities (from wells) on the shelf \\
\hline & $1000<z<1630$ & $2488-3750$ & Gradual Increase of velocity \\
\hline & $z=1630$ & 3750 & Maximal velocity at Autan 1 \\
\hline & $1630<z<2950$ & $3750-3150$ & Gradual Decrease of velocity \\
\hline & $z=2950$ & 3150 & Velocity around $\mathrm{GLP} 2=3150 \mathrm{~m} / \mathrm{s}$ \\
\hline & $2950<z<3400$ & $3150<v<3050$ & Little decrease of velocity until location of ESP203 \\
\hline & $3400<z<4477$ & $3050>v>2800$ & Gradual decrease of velocity in the basin between ESP203 et ESP206 \\
\hline \multirow{5}{*}{$\begin{array}{c}\text { Top of Messinian } \\
- \text { - } 11\end{array}$} & $0<z<1300$ & $2825 \ldots$ & Average velocities (from wells on the shelf) or velocity law established by Lofi et al.,2003 \\
\hline & $1300<z<1925$ & $2825<v<3700$ & Gradual Increase of velocity (unit between the MES and the Abrasion Surface) \\
\hline & $1925<z<3350$ & 3700 & Constant velocity until GLP2 (unit between the Abrasion Surface and the Base of Salt around ESP202) \\
\hline & $3350<z<4070$ & $3700<v<4500$ & Gradual decrease of velocity towards the basin until location of ESP203 \\
\hline & $4070<z<5508$ & 4500 & Constant and maximal velocity between ESP203 and ESP205 \\
\hline Base of LU & $\min (2627)<z<\max (5974)$ & 4700 & Constant velocity between ESP203 and 206 \\
\hline \multirow{4}{*}{ Base of the MSC } & $1498<z<2215$ & 4000 & Velocity on the slope at Autan 1 \\
\hline & $2215<z<3925$ & $4000<\mathrm{v}<4100$ & Little increase of velocity between Autan and GLP2 \\
\hline & $3925<z<4900$ & $4100<v<5150$ & Gradual Increase of velocity between GLP2 et ESP203 \\
\hline & $4900<z<6588$ & 5150 & Constant and maximal velocity between ESP203 and ESP206 \\
\hline \multirow{3}{*}{ Substratum } & $170<z<3100$ & 4800 & Mean and constant velocity (from data wells including Autan 1) on the shelf and inner slope \\
\hline & $3100<z<5000$ & $4800<v<5300$ & Gradual increase of velocity between ESP 202 and ESP20 3 \\
\hline & $5000<z<7257$ & 5300 & Constant and maximal velocity between ESP203 and ESP206 \\
\hline
\end{tabular}




\begin{tabular}{|c|c|c|c|c|c|c|c|c|c|c|c|}
\hline Stratigraphic units & Volumes $\left(\mathrm{km}^{3}\right)$ & \multicolumn{4}{|c|}{ Ages (Ma) } & & uration (Myr) & \multicolumn{4}{|c|}{ Flux $\left(\mathrm{km}^{3} / \mathrm{Myr}\right)$} \\
\hline Q5-Seafloor & 7467 & \multicolumn{4}{|c|}{$0.45-0$} & \multicolumn{2}{|c|}{0.45} & \multicolumn{4}{|c|}{16600} \\
\hline Q10-Q5 & 7240 & \multicolumn{4}{|c|}{$0.90-0.45$} & \multicolumn{2}{|r|}{0.45} & \multicolumn{4}{|c|}{16090} \\
\hline $\mathrm{PXX}-\mathrm{Q} 10$ & 5850 & \multicolumn{4}{|c|}{$1.60-0.90$} & \multicolumn{2}{|r|}{0.70} & \multicolumn{4}{|c|}{8360} \\
\hline P11-PXX & 6621 & \multicolumn{4}{|c|}{$2.60-1.60$} & \multicolumn{2}{|r|}{1.00} & \multicolumn{4}{|c|}{6620} \\
\hline Top of Messinian-P11 & 25713 & \multicolumn{4}{|c|}{$5.33-2.60$} & \multicolumn{2}{|r|}{2.73} & \multicolumn{4}{|c|}{9420} \\
\hline PLIO-PLEISTOCENE & 53040 & \multicolumn{4}{|c|}{$5.33=0$} & \multicolumn{2}{|r|}{5.33} & \multicolumn{4}{|c|}{9950} \\
\hline M3 & 402 & \multicolumn{4}{|c|}{$5.60-5.33$} & \multicolumn{2}{|r|}{0.27} & \multicolumn{4}{|c|}{1480} \\
\hline UU & 4880 & $5.96-5.33$ & $5.96-5.60$ & $5.60-5.33$ & $5.46-5.33$ & 0.63 & \begin{tabular}{|l|l|l|}
0.36 & 0.27 & 0.13 \\
\end{tabular} & 7750 & 13550 & 18075 & 35540 \\
\hline MU & 12934 & $5.96-5.33$ & $5.96-5.60$ & $5.60-5.33$ & $5.46-5.33$ & 0.63 & \begin{tabular}{|l|l|l|}
0.36 & 0.27 & 0.13 \\
\end{tabular} & 20530 & 35930 & 47900 & 99490 \\
\hline M2 & 1192 & $5.96-5.33$ & $5.96-5.60$ & $5.60-5.33$ & $5.46-5.33$ & 0.63 & \begin{tabular}{|l|l|l|}
0.36 & 0.27 & 0.13 \\
\end{tabular} & 1900 & 3310 & 4415 & 9170 \\
\hline LU1 & 20768 & $5.96-5.33$ & $5.96-5.60$ & $5.96-5.46$ & & 0.63 & \begin{tabular}{|l|l|l|}
0.36 & 0.50 & \\
\end{tabular} & 32965 & 57690 & 41535 & \\
\hline LU0 & 20558 & $5.96-5.33$ & $5.96-5.60$ & $5.96-5.46$ & & 0.63 & \begin{tabular}{|l|l|}
0.36 & 0.50 \\
\end{tabular} & 32630 & 57105 & 41115 & \\
\hline Detrital with hypothesis from Lofi, 2002 & 1594 & $5.96-5.33$ & $5.96-5.60$ & $5.96-5.46$ & & 0.63 & \begin{tabular}{|l|l|}
0.36 & 0.50 \\
\end{tabular} & 2530 & 4430 & 3190 & \\
\hline Detrital with hypothesis from Bache, 2009 & 22152 & $5.96-5.33$ & $5.96-5.60$ & $5.96-5.46$ & & 0.63 & $0.36 \quad 0.50$ & 35160 & 61530 & 44300 & \\
\hline Evaporites and salt & 38582 & \multicolumn{4}{|c|}{$5.96-5.33$} & \multicolumn{2}{|c|}{0.63} & \multicolumn{4}{|c|}{$\begin{array}{r}61240 \\
\end{array}$} \\
\hline MESSINIAN with hypothesis from Lofi, 2002 & 39774 & \multicolumn{4}{|c|}{$5.96-5.33$} & & 0.63 & \multicolumn{4}{|c|}{63135} \\
\hline MESSINIAN with hypothesis from Bache, 2009 & 60332 & \multicolumn{4}{|c|}{$5.96-5.33$} & & 0.63 & \multicolumn{4}{|c|}{95765} \\
\hline pre Messinian Miocene with hypothesis from Bache, 2009 & 39660 & \multicolumn{4}{|c|}{$23-5.96$} & & 17.04 & \multicolumn{4}{|c|}{2327} \\
\hline pre Messinian Miocene with hypothesis from Lofi, 2002 & 60218 & & & & & & 17.04 & & & 3533 & \\
\hline OLIGO-MIOCENE (Basement-Top of Messinian) & 114696 & & & & & & 17.67 & & & 6490 & \\
\hline VOLUME TOTAL (Basement-Seafloor) & 167736 & & & & & & 23 & & & 7290 & \\
\hline
\end{tabular}




\begin{tabular}{|c|c|c|c|c|c|c|c|c|c|c|c|c|c|c|c|c|c|c|c|}
\hline Units & Lithologies & $\begin{array}{l}\text { Mean } \\
\text { burial } \\
\text { depth }\end{array}$ & $\begin{array}{l}\text { Initial } \\
\text { porosity } \\
(\%)\end{array}$ & $\begin{array}{l}\text { Final } \\
\text { porosity } \\
\text { (\%) }\end{array}$ & $\begin{array}{c}\text { Loss of } \\
\text { porosity } \\
\text { (\%) }\end{array}$ & \multicolumn{2}{|c|}{$\begin{array}{c}\text { Compacted volumes (Sediments + } \\
\text { porosity) }\left(\mathrm{km}^{3}\right)\end{array}$} & \multirow{2}{*}{$\begin{array}{c}\begin{array}{c}\text { Final porous } \\
\text { volumes }\left(\mathrm{km}^{3}\right)\end{array} \\
3285 \\
568\end{array}$} & \multicolumn{2}{|c|}{$\begin{array}{l}\text { Initial porous } \\
\text { volumes }\left(\mathrm{km}^{3}\right)\end{array}$} & \multicolumn{3}{|c|}{$\begin{array}{c}\text { Solid Sediment volumes (zero } \\
\text { porosity) }\left(\mathrm{km}^{3}\right)\end{array}$} & \multicolumn{3}{|c|}{$\begin{array}{l}\text { Initial porous volumes + } \\
\text { Sediment volumes }(\mathbf{k m} 3)\end{array}$} & \multirow{2}{*}{$\begin{array}{c}\begin{array}{c}\text { Duration } \\
\text { (Ma) }\end{array} \\
0.45\end{array}$} & \multirow{2}{*}{\begin{tabular}{|c|}
$\begin{array}{c}\text { Solid sediment } \\
\text { fluxes (zero } \\
\text { porosity) }\left(\mathrm{km}^{3} / \mathrm{Ma}\right)\end{array}$ \\
8032 \\
\end{tabular}} & \multirow{2}{*}{\begin{tabular}{|c}
$\begin{array}{c}\text { Uncompacted } \\
\text { sediment fluxes } \\
\text { (km³/Myr) }^{3} \text { ( }\end{array}$ \\
18652
\end{tabular}} \\
\hline Q5-Seafloor & $80 \%$ clay & $\begin{array}{l}0 m- \\
227 m\end{array}$ & $70 \%$ & $55 \%$ & $15 \%$ & \multirow[t]{2}{*}{7467} & $\begin{array}{l}5974 \\
1494\end{array}$ & & $\frac{4181}{598}$ & 4779 & 2689 & 3615 & & 6870 & 8393 & \multirow{10}{*}{$\begin{array}{c}\text { Pliocene \& } \\
\text { Pleistocene: } \\
68165\end{array}$} & & & \\
\hline \multirow{2}{*}{ Q10-Q5 } & $\begin{array}{l}20 \% \text { sana } \\
80 \% \text { clay }\end{array}$ & $227 \mathrm{~m}-$ & $\begin{array}{l}40 \% \\
70 \% \\
\end{array}$ & $50 \%$ & $2 \%$ & & $\begin{array}{l}1494 \\
5792\end{array}$ & $\begin{array}{c}568 \\
2896\end{array}$ & $\begin{array}{c}598 \\
4054\end{array}$ & \multirow[b]{2}{*}{4634} & $\begin{array}{r}926 \\
2896\end{array}$ & \multirow[b]{2}{*}{3822} & & $\begin{array}{l}1524 \\
6950\end{array}$ & \multirow[b]{2}{*}{8456} & & \multirow{2}{*}{0.45} & \multirow[b]{2}{*}{8493} & \multirow{2}{*}{18792} \\
\hline & $20 \%$ sand & $438 \mathrm{~m}$ & $40 \%$ & $36 \%$ & $4 \%$ & 7240 & 1448 & 522 & 580 & & 926 & & & 1506 & & & & & \\
\hline \multirow{2}{*}{ PXX-Q10 } & $80 \%$ clay & $438 m-$ & $70 \%$ & $45 \%$ & $25 \%$ & \multirow{2}{*}{5850} & 4680 & 2106 & 3276 & \multirow{2}{*}{3744} & 2574 & 3335 & Pliocene \& & 5850 & 7079 & & 0.90 & 3705 & 7865 \\
\hline & $20 \%$ sand & $646 \mathrm{~m}$ & $40 \%$ & $35 \%$ & $5 \%$ & & 1170 & 410 & 468 & & 761 & 3335 & Pleistocene: & 1229 & 1019 & & 0.70 & 4764 & 10112 \\
\hline & $80 \%$ clay & $646 \mathrm{~m}-$ & $70 \%$ & $40 \%$ & $30 \%$ & & 5297 & 2119 & 3708 & & 3178 & 4065 & 34957 & 6886 & & & 0.80 & 5082 & 10378 \\
\hline P11-PXX & $20 \%$ sand & $886 \mathrm{~m}$ & $40 \%$ & $33 \%$ & $7 \%$ & 6621 & 1324 & 437 & 530 & $423 /$ & 887 & 4063 & & $14: 7$ & 8303 & & 1.00 & 4065 & 8303 \\
\hline & $70 \%$ clay & & $70 \%$ & $20 \%$ & $50 \%$ & & 17999 & 3600 & 12599 & & 14399 & & & 26999 & & & & & \\
\hline Messinian Top-P11 & $25 \%$ sand & $1803 \mathrm{~m}$ & $40 \%$ & $25 \%$ & $15 \%$ & 25713 & 6428 & 1607 & 2571 & 15813 & 4821 & 20120 & & 7392 & 35934 & & 2.73 & 7370 & 13163 \\
\hline & $5 \%$ carbonate & & $50 \%$ & $30 \%$ & $20 \%$ & & 1286 & 386 & 643 & & 900 & & & 1543 & & & & & \\
\hline M3 unit & $30 \%$ clay & $1803 \mathrm{~m}-$ & $70 \%$ & $15 \%$ & $55 \%$ & 402 & 121 & 18 & 84 & & 103 & & & 187 & & & & & \\
\hline Mis unit & $70 \%$ sand & $1903 \mathrm{~m}$ & $40 \%$ & $22,5 \%$ & $17.5 \%$ & 402 & 281 & 63 & 113 & 197 & 218 & 321 & 321 & 331 & 518 & 518 & 0.63 & 509 & 822 \\
\hline & $40 \%$ clay & & $70 \%$ & $15 \%$ & $55 \%$ & & 1952 & 293 & 1366 & & 1659 & & & 3026 & & & & & \\
\hline Upper Unit (UU) & $10 \%$ sand & $2065 \mathrm{~m}$ & $40 \%$ & $22,5 \%$ & $17.5 \%$ & 4880 & 488 & 110 & 195 & ? & 378 & ? & ? & 573 & ? & & 0.63 & ? & ? \\
\hline & \begin{tabular}{|l|}
$50 \%$ evaporite \\
\end{tabular} & & $?$ & $?$ & $?$ & & 2440 & $?$ & $?$ & & $?$ & & & $?$ & & & & & \\
\hline Mobile Unit (MU) & $100 \%$ halite & $\begin{array}{r}2065 \mathrm{~m} \\
2566 \mathrm{~m}\end{array}$ & ? & ? & ? & 12934 & 12934 & ? & ? & ? & ? & ? & ? & ? & ? & $\begin{array}{l}\text { Part of } \\
\text { Messinian } \\
\text { evaporites }\end{array}$ & 0.63 & ? & $?$ \\
\hline & $40 \%$ clay & & $70 \%$ & $10 \%$ & $60 \%$ & & 8307 & 831 & 5815 & & 7476 & & & 13292 & & & & & \\
\hline Lower Unit (LU1) & $10 \%$ sand & $2566 \mathrm{~m}-$ & $40 \%$ & $12,50 \%$ & $27.5 \%$ & 20768 & 2077 & 260 & 831 & ? & 1817 & ? & ? & 2648 & ? & & 0.63 & ? & ? \\
\hline & $50 \%$ evaporite? & & $?$ & $?$ & $?$ & & 10384 & $?$ & $?$ & & & & & $?$ & & & & & \\
\hline Late Messinian & $80 \%$ clay & $1903 \mathrm{~m}-$ & $70 \%$ & $15 \%$ & $55 \%$ & & 954 & 143 & 668 & & 811 & & & 1478 & & & & & \\
\hline detritism (M2 unit) & $20 \%$ sand & $2003 \mathrm{~m}$ & $40 \%$ & $22,50 \%$ & $17.5 \%$ & 1192 & 238 & 54 & 95 & 763 & 185 & 995 & & 280 & 1758 & Messinian & 0.63 & 1580 & 2791 \\
\hline & $50 \%$ clay & & $70 \%$ & $7,50 \%$ & $62.5 \%$ & & 10279 & 771 & 7195 & & 9508 & & detritism & 16703 & & detritism : & 0.63 & 29776 & 49029 \\
\hline Early IVessinlan & $10 \%$ sand & $3800 \mathrm{~m}-$ & $40 \%$ & $10 \%$ & $30 \%$ & 20558 & 2056 & 206 & 822 & 12129 & 1850 & 18759 & & 2673 & 30888 & & & & \\
\hline & \begin{tabular}{|l|}
$40 \%$ carbonate \\
\end{tabular} & $4 / 11 \mathrm{~m}$ & $50 \%$ & $10 \%$ & $40 \%$ & & 8223 & 822 & 4112 & & 7401 & & & 11512 & & & 17.04 & 712 & 1813 \\
\hline & $70 \%$ clay & & $70 \%$ & $7,50 \%$ & $62.5 \%$ & & 22274 & 1671 & 15592 & & 20603 & & $\begin{array}{l}\text { Mlocene : } \\
29434 / 48\end{array}$ & 36195 & & $\begin{array}{l}\text { Nilocene: } \\
49480 / 80\end{array}$ & & & \\
\hline Pre-Messinian Miocene & \begin{tabular}{|l|}
$10 \%$ sand \\
\end{tabular} & $6545 \mathrm{~m}$ & $40 \%$ & $7,50 \%$ & $32.5 \%$ & 31820 & 3182 & 239 & 1273 & 20047 & 2943 & 29434 & $29434 / 48$ & 4216 & 49480 & $\begin{array}{l}49480 / 80 \\
368\end{array}$ & 17.04 & 1176 & 2904 \\
\hline & $30 \%$ carbonate & & $50 \%$ & $7,50 \%$ & $42,50 \%$ & & 6364 & 477 & 3182 & & 5887 & & & 9069 & & & & & \\
\hline
\end{tabular}

